\title{
Synthetic Approaches to Radiochemical Probes for Imaging of
}

\section{Bacterial Infections}

Jyotibon Dutta ${ }^{1}$, Tricia Naicker ${ }^{1}$, Thomas Ebenhan ${ }^{2}$, Hendrik G. Kruger ${ }^{1}$, Per I. Arvidsson $^{1,3}$ and Thavendran Govender ${ }^{1 *}$

\section{Affiliations:}

${ }^{1}$ Catalysis and Peptide Research Unit, School of Health Sciences and School of Chemistry and Physics, University of KwaZulu-Natal, Durban 4001, South Africa

${ }^{2}$ University of Pretoria \& Steve Biko Academic Hospital, Crn Malherbe and Steve Biko Rd, Pretoria, 0001, South Africa.

${ }^{3}$ Science for Life Laboratory, Drug Discovery and Development Platform and Division of Translational Medicine and Chemical Biology, Department of Medical Biochemistry and Biophysics, Karolinska Institutet SE-171 77 Stockholm, Sweden

\section{Corresponding author is marked *}

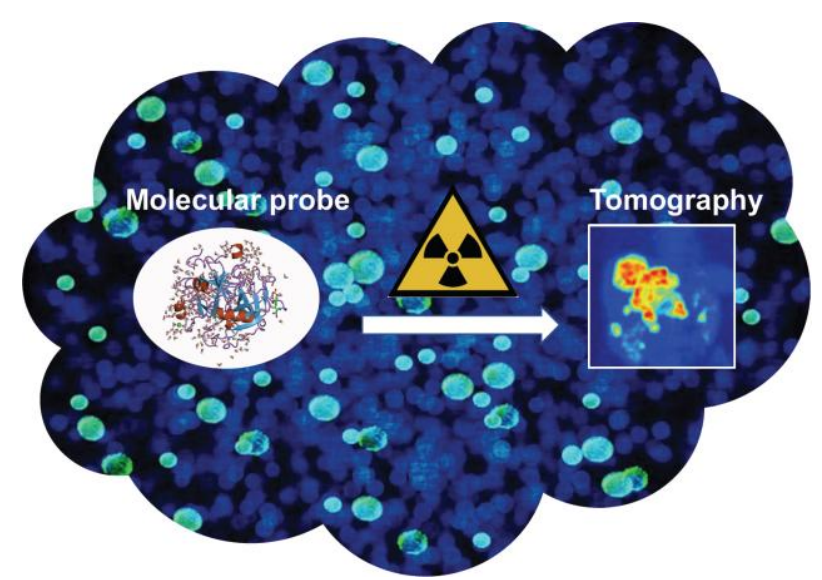

\begin{abstract}
This present review provides an account on the available synthetic strategies employed to radiolabel commercial and potential bacteria-selective probes for tomographic imaging. These molecular probes encompass leukocytes, antibodies, small molecules,
\end{abstract}


peptides, antibiotics, macrolides, vitamins, oligomers and siderophores. Although this technique has shown to be a valuable tool for non-invasive infection imaging, more development is required to create easy-to-radiolabel kit solutions/procedures for the preparation of the probes.

\section{Contents}

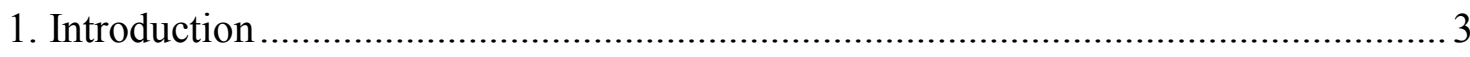

2. Commercially available infection imaging probes: ............................................... 5

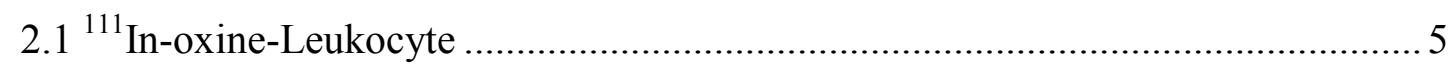

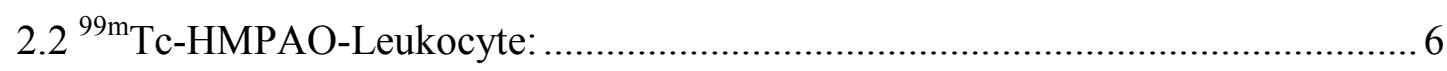

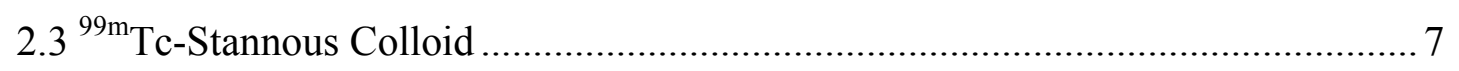

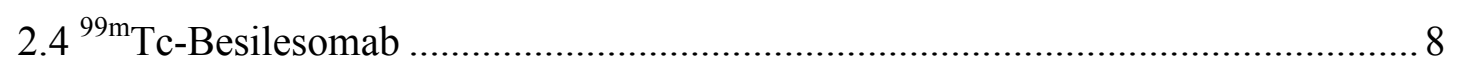

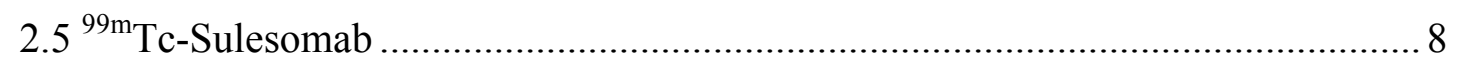

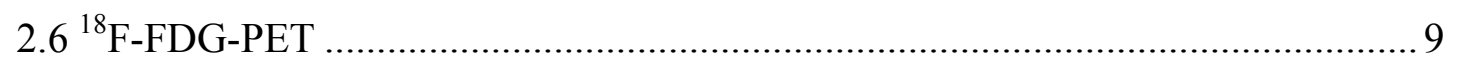

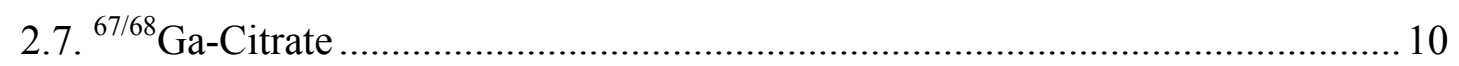

3. Novel imaging probes for direct, more specific imaging of bacterial infection ........ 13

3.1 Antimicrobial peptides as bacteria-selective imaging probes ............................ 13

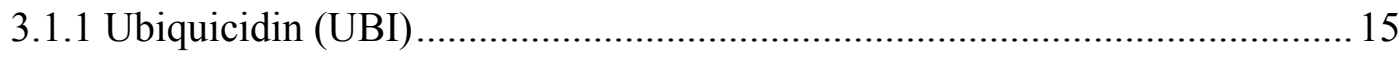

3.1.2 Human neutrophil peptide (HNP) ....................................................... 18

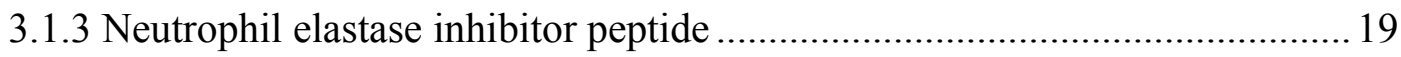

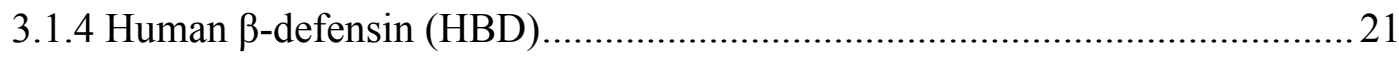

3.1.5 Human lactoferrin-derived peptide (hLF) ............................................. 21

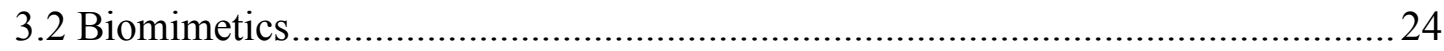

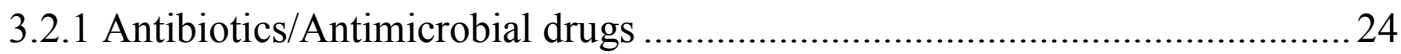

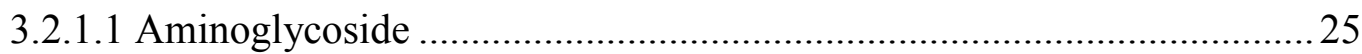

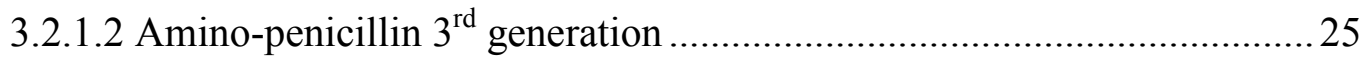

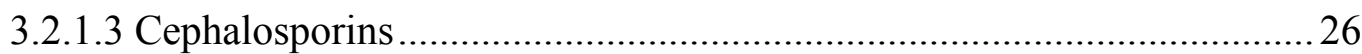

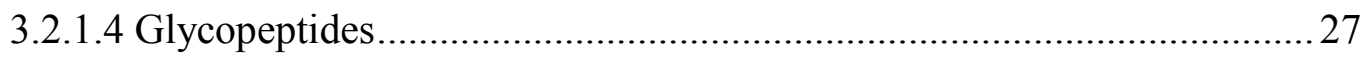

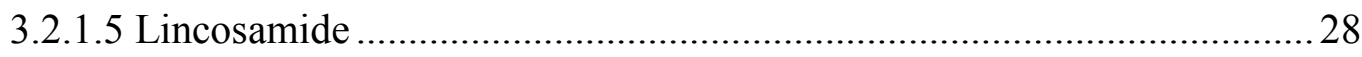

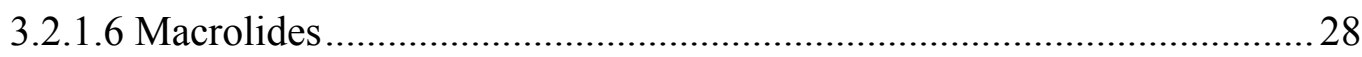

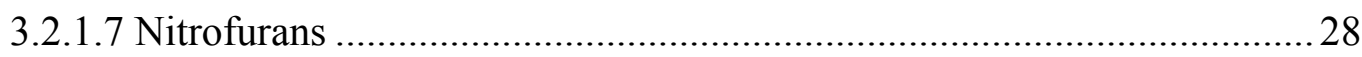

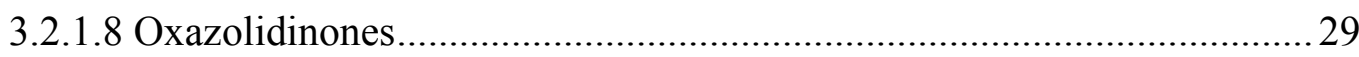


3.2.1.9 Fluoroquinolones 30

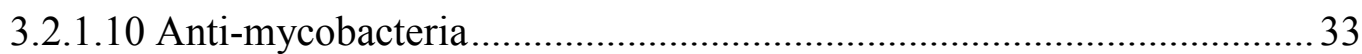

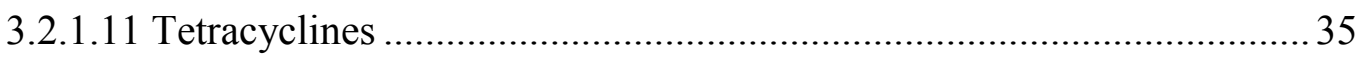

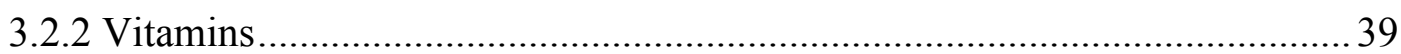

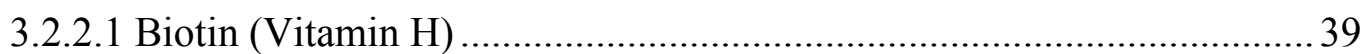

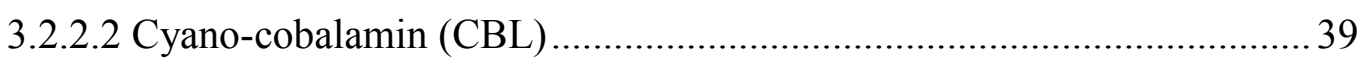

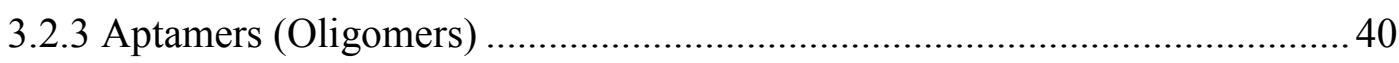

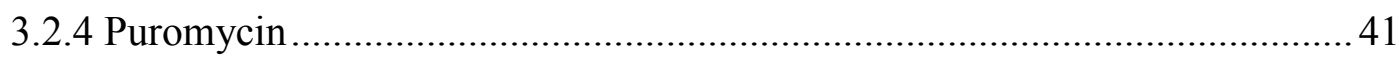

3.2.5 Radiolabeled purines and pyrimidines................................................... 42

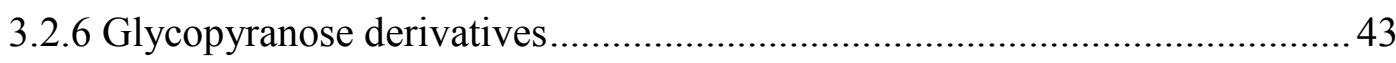

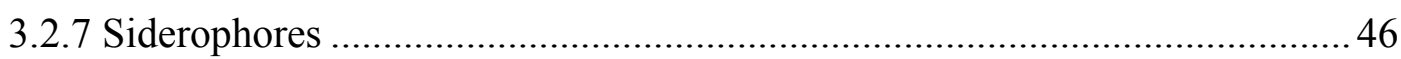

4. Challenges and limitations in producing efficient infection imaging probes ............ 49

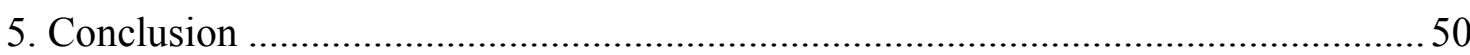

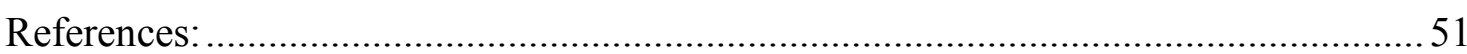

\section{Introduction}

Throughout the world, bacterial infections remain a major cause for human morbidity and mortality [1]. Infectious diseases are one of the oldest challengers for humans; and can be ranked with war and famine [2]. In this current era, the growing incident of infection and the development of drug resistance have a huge impact on the global economy and human health [2]. Early detection of bacterial infection is crucial for the prognosis of the disease but insignificant progress has been done in this field. Conventional ways for bacterial diagnosis are based on either or combination of biochemical, physical and bacterial cultures where the bacterial culturing can be considered as the gold standard method [3]. However, bacterial culture methods do not provide in vivo localization of the infection or reservoirs. With the advancement of modern day technology, various diagnostic tools bear the potential for locating the site of infection. Radiological techniques such as computed tomography (CT) can be 
advantageous for imaging bacterial infections but it is only useful when there is a significant anatomical change in potentially infected tissues. Likewise, magnetic resonance imaging (MRI) can be applied for bacterial imaging aided by specific probes but it is limited to patients without claustrophobia or implanted medical devices. Nuclear medicine techniques such as single photon emission computed tomography (SPECT) and positron emission tomography (PET) stand out as potential candidates because these techniques are able to locate the site of infection with the help of a radiolabeled biomolecule/probe [4]. Available SPECT- or PET-based probes consist of in vitro or in vivo (for example) radiolabeled leukocytes. There are recurring comprehensive reports on the clinical use of commercially available radiotracers targeting infection and inflammation $[5,6]$. The radiolabeled probes under current studies showed the potential for targeting molecular components of bacteria or its metabolites resulting in specific identification of the infection site in contrast to the sterile inflammation [7-10]. This field of study is also positively influenced and expanding due to the hybridization of imaging techniques such as PET(SPECT)/CT or PET(SPECT)/MRI [11].

Herein, we aim to provide a concise guide to the synthetic approaches of molecular radiotracers with focus on bacterial imaging. This review is divided into commercially available and novel probes as followed: i) clinical/preclinical availability, ii) probe functionalizing via suggested radiolabeling procedures and iii) probe distribution and suggested mechanisms of the probe uptake, internalization and signal amplification. At the end of each class of radiolabeled probe, is a table summary of the transformations that provides information on the non-radiolabeled core, radioisotope, disease target, labeling efficiency and technique used for detection of the radiotracer. 


\section{Commercially available infection imaging probes}

Most of the clinically used radiotracers for infection detection are based on leukocytes due to the fact that there is an influx of leukocytes during inflammation. A few of these radiopharmaceuticals are Food and Drug Administration (FDA) approved. These commercially available radiotracers can be divided broadly into i) radiolabeled leukocytes $\quad\left({ }^{111}\right.$ In-oxine-leukocyte, ${ }^{99} \mathrm{~m}$ Tc-HMPAO-leukocute and ${ }^{99 m}$ Tc-Stannous Colloid), ii) radiolabeled anti-granulocyte antibodies $\left({ }^{99 \mathrm{~m}} \mathrm{Tc}-\right.$ Besilesomab and ${ }^{99 \mathrm{~m}} \mathrm{Tc}-$ Sulesomab), iii) unspecific biomolecules such as 2-deoxy-2- $\left({ }^{18} \mathrm{~F}\right)$ fluoro-D-glucose $\left({ }^{18} \mathrm{~F}\right.$ FDG) and ${ }^{67 / 68}$ Ga-citrate.

\section{$2.1^{111}$ In-oxine-Leukocyte}

The current "gold standard" tomographic imaging technique targeting infection is considered to be direct leukocyte labeling with radio metals [12]. Efficient labeling of leukocytes and its imaging can be obtained with ${ }^{111}$ In-oxine because of its long halflife [13]. Detection and localization of the infectious site is the prime area of interest for ${ }^{111}$ In-oxine-leukocyte which included various clinical presentations such as pulmonary infection including tuberculosis, endocarditis, neurological infections, fever of unknown origin, diabetic foot, inflammatory bowel disease, infected central venous catheters or other devices; infected joint and vascular prosthesis, postoperative abscesses and osteomyelitis of the appendicle skeleton [14-16]. Roca et al. described a method of radiolabeling necessitating at least $2 \times 10^{8}$ leukocytes for good labeling efficiencies [14]. A whole-blood sample was collected from the patient in acid-citratedextrose (ACD) anticoagulant solution containing vial, at a blood /ACD ratio of 1:5.6. Out of that, $15 \mathrm{ml}$ of the mixture was centrifuged at $2000 \mathrm{~g}$ for $10 \mathrm{~min}$ at room temperature to separate the blood cells from the cell free plasma (CFP) and the latter 
was used as re-suspending medium after labeling in the subsequent steps. Leukocyte isolation was initiated by separating the erythrocytes with $10 \%$ 2-hydroxyethyl starch (HES) (molecular weight $200 / 0.5$ or $200 / 0.6$ ) by sedimentation. Recommended bloodACD solution to HES ratio was 10:1 and the leukocyte-rich plasma (LRP) was collected with a 20G lumbar needle without disturbing the erythrocyte layer which was followed by centrifugation at $150 \mathrm{~g}$ for $5 \mathrm{~min}$. Platelet-rich plasma (PRP) was removed and the mixed leukocyte pellet was gently re-suspended. An optional PBD/saline wash was advised to reduce the number of platelets. For radiolabeling, $20 \mathrm{MBq}$ of ${ }^{111} \mathrm{In}-$ oxine was incubated with the isolated mixed leukocyte cell suspension for $10 \mathrm{~min}$ at room temperature with gentle periodic swirling. The authors recommended working with HEPES buffer (about $6 \mathrm{mg} / \mathrm{ml}$ final concentration) if ${ }^{111}$ In-oxine has to be used without the buffer provided by the manufacturer. After incubation, at least $3 \mathrm{ml}$ (up to a maximum of $10 \mathrm{ml}$ ) of PBS/saline was added to the solution and centrifuged at $150 \mathrm{~g}$ for 5 min. The supernatant containing the unbound ${ }^{111}$ In-oxine was removed and used to calculate the labeling efficiency. Radioactivity was measured in the leukocyte pellet and subsequently dissolved in 3-5 $\mathrm{ml}$ of previously extracted CFP [14].

During the process of leukocyte labeling with ${ }^{111}$ In-oxine, it diffused through the lipid bilayer of the cell because of its neutral and lipophilic nature. Upon internalization, the ${ }^{111}$ In-complexes (i.e. the radioisotope) irreversibly associate with intercellular and nucleus components and free oxine may experience cellular efflux.

\section{$2.2^{99 m}$ Tc-HMPAO-Leukocyte:}

Technetium-99m ( $\left.{ }^{99 \mathrm{~m}} \mathrm{Tc}\right)$ can be chelated with hexamethylpropyleneamine oxine (HMPAO) and has been used as a non-invasive diagnosis tool for numerous physiological abnormalities [17]. The SPECT radioisotope ${ }^{99 \mathrm{~m}} \mathrm{Tc}$ - can be chelated with 
HMPAO, which facilitates the uptake into cells [18]. Leukocyte labeling with ${ }^{99 \mathrm{~m}} \mathrm{Tc}$ HMPAO follows a similar technique such as ${ }^{111}$ In-oxine; i.e. it needs the separation of WBC from the whole blood. Once inside the cell, ${ }^{99 m} \mathrm{Tc}-\mathrm{HMPAO}$ changes its lipophilic character to non-diffusible hydrophilic complexes and becomes trapped [19]. This compound has a half-life of $6 \mathrm{~h}$ and emits $140-\mathrm{keV} \gamma$-rays which can be detected by a SPECT camera [20]. The normal probe bio-distribution can be seen mainly in the kidney, liver and spleen with notable activity in the gastrointestinal tract and bone marrow. Hence, imaging of hepatic and splenic infections using ${ }^{99 \mathrm{~m}}$ Tc-HMPAOLeukocyte SPECT may lead to suboptimal image interpretation [20].

\section{$2.3^{99 m}$ Tc-Stannous Colloid}

${ }^{99 \mathrm{~m}} \mathrm{Tc}$-labled stannous colloids $\left({ }^{99 \mathrm{~m}} \mathrm{Tc}-\mathrm{SnC}\right)$ is a radiolabeling technique to label neutrophils and monocytes for imaging of inflammation and spatial localization of infection for gram-positive as well as gram-negative bacteria [21-26]. The radiolabeling of leukocytes does not require its separation from the whole blood as ${ }^{99} \mathrm{~m}$ Tc-SnC can selectively bind to the target immune cells in the infection site which make it simpler and less expensive compared to other labeling agents $[21,27,28]$. The ${ }^{99 \mathrm{~m}} \mathrm{Tc}-\mathrm{SnC}$ has a shelf-life of up to $6 \mathrm{~h}$ [29]. Colloid incubation with a heparinized patient whole blood sample (up to $20 \mathrm{~mL}$ ) comprises of a $1 \mathrm{~h}$ syringe rotation followed by a brief centrifugation step to part cells and plasma supernatant prior to cell resuspension and re-administration into the patient. It should be noted that ${ }^{99 \mathrm{~m}} \mathrm{Tc}-\mathrm{SnC}$ labeled blood cells cannot distinguish between sterile inflammation and infection [30]. It has unanimously been reported that its labeling efficiency is more than $95 \%$ using whole blood samples [27, 28, 31-33]. The detailed mechanism of action concerning ${ }^{99} \mathrm{~m}$ Tc-SnC-labeling leukocytes may not be entirely understood [21, 22, 27, 34-36]; it is 
hypothesized that phagocytosis of the colloidal compounds and/or its reversible binding of the leukocyte to cell membranes may occur.

\section{$2.4^{99 m}$ Tc-Besilesomab}

Besilesomab, a murine derived monoclonal antibody of the IgG1 $\kappa$ isotype with a molecular weight of $150 \mathrm{kDa}$, targets the NCA-95 epitope of granulocyte or granulocyte precursors. After injection of ${ }^{99 \mathrm{~m}} \mathrm{Tc}-\mathrm{Besilesomab}$ to the recipient, $10 \%$ of the compound binds to neutrophils whereas $20 \%$ of them freely circulate and localize in infected sites through a non-specific mechanism $[37,38] .{ }^{99 \mathrm{~m}} \mathrm{Tc}-$ Besilesomab can be used for the diagnosis of pyrexia of unknown origin, appendicitis, acute myocarditis and diabetic pedal osteomyelitis but it showed variable results in the case of joint infection and inflammatory bowel disease [39-43]. Radiopharmaceutical preparation of ${ }^{99 \mathrm{~m}}$ Tc-Besilesomab is marketed under the trade name Scintimun ${ }^{\circledR}$ and the kit contains Besilesomab with pre-reduced disulfide bonds. Generator-eluted ${ }^{99 \mathrm{~m}}$ Tc-sodium pertechnetate is reduced by the stannous chloride (provided as a kit vial component) yielding ${ }^{99 \mathrm{~m}} \mathrm{Tc}(\mathrm{IV})$, which in turn binds to the free thiol groups of the reduced Besilesomab [44]. The usage of Scintimun ${ }^{\circledR}$ might be challenged by: the risk of the pattern of human anti-mouse antibodies (HAMA) response, i.e. eliminates repeated probe administrations, a delayed probe accumulation at the infected site due to the high molecular weight of the antibody, and significant unspecific probe uptake in the liver and bone marrow [45]. ${ }^{99 \mathrm{~m}} \mathrm{Tc}$-Besilesomab-SPECT imaging is unspecific for infection.

\section{$2.5^{99 m}$ Tc-Sulesomab}

${ }^{99 \mathrm{~m}}$ Tc-Sulesimab is a sensitive probe primarily used to detect musculoskeletal infections. It also showed to be useful in the case of diagnosing pyrexia of unknown origin as well as infection in soft tissues [46]. Sulesomab is a murine originated 
fragment antigen binding (Fab) portion of an $\mathrm{IgG}_{1}$ and can couple to ${ }^{99 \mathrm{~m}} \mathrm{Tc}$ through its thiol groups. This fragment is $50 \mathrm{kDa}$ and can bind to leukocytes through the normal cross-reactive antigen-90 (NCA-90) [38]. After infusion, 34\% of ${ }^{99 \mathrm{~m}} \mathrm{Tc}-$ sulesomab can be detected in the blood after $1 \mathrm{~h}$ and at $4 \mathrm{~h}$ the radioactivity starts to wash out with only $7 \%$ of the injected dose remaining in the body after $24 \mathrm{~h}$. This tracer shows higher affinity towards the activated rather than latent granulocytes, thus in vivo radiolabeling is likely to occur at the inflammation site rather than to circulating granulocytes [46]. The commercially available sulesimab (LeukoScan ${ }^{\circledR}$ ) kit comprises of sulesomab, stannous chloride dihydrate, potassium sodium tartrate tetrahydrate, sodium acetate trihydrate, sodium chloride, glacial acetic acid (trace), hydrochloric acid (trace) and sucrose under the nitrogen. These lyophilized components are reconstituted in a solution of sodium chloride before adding the radioactivity with a simple $10 \mathrm{~min}$ incubation at room temperature is needed to achieve ${ }^{99 \mathrm{~m}} \mathrm{Tc}-\mathrm{Sulesimab}$ [47]. The final formulation has $\mathrm{pH}$ values of 4.5-5.5 with the shelf-life of the probe being $4 \mathrm{~h}$.

\section{$2.6^{18} F-F D G-P E T$}

Aside from mainly imaging oncologic abnormalities, ${ }^{18}$ F-FDG-PET is also a technique to image infection and inflammation [48]. The mechanism of ${ }^{18}$ F-FDG-PET for infection imaging is due to an elevated glucose demand by mononuclear and granulocyte cells during their metabolic eruption when activated [49-53]. Moreover, glucose is also utilized by proliferating fibroblasts [54] but again, this technique cannot distinguish between infection and sterile inflammation. Hamacher et al. described a nucleophilic substitution of ${ }^{18} \mathrm{~F}$-fluoride for the synthesis of ${ }^{18} \mathrm{~F}$-FDG where they used 1,3,4,6-tetra- $O$-acetyl-2- $O$-trifluoromethanesulfonyl-d-manno-pyranose as a precursor (Scheme 1) [55]. The major drawback of this method is the activation of the ${ }^{18} \mathrm{~F}$ - 
fluoride for the nucleophilic substitution reaction which needs an azeotropic drying step $[56]$.
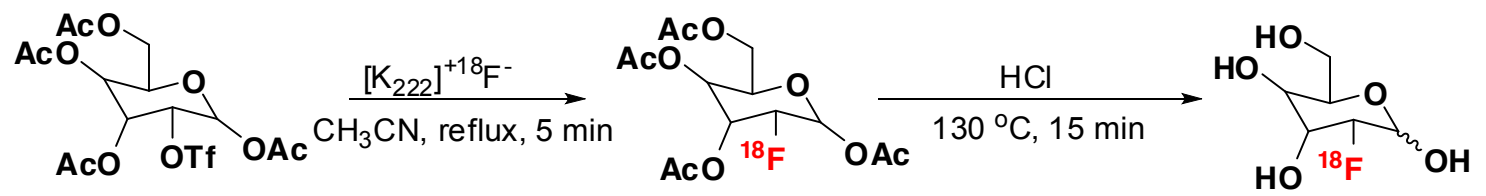

$\mathrm{Tf}=-\mathrm{SO}_{2} \mathrm{CF}_{3}$

Scheme 1. Synthesis of 2-deoxy-2-( $\left.{ }^{18} \mathrm{~F}\right)$ fluoro-D-glucose

\section{7. ${ }^{67 / 68}$ Ga-Citrate}

The former gold standard of infection imaging, gallium-67 $\left({ }^{67} \mathrm{Ga}\right)$-labeled citrate has been in use as a probe since 1984 [57]. However, the mechanism of uptake of ${ }^{67 / 68} \mathrm{Ga}$ citrate is still not entirely clear. There are several factors which can affect the accumulation of this compound around the infection site; this includes direct leukocyte binding, complexation to siderophores, or binding to lactoferrin and transferrin [58]. With the advent of germanium-68 $\left({ }^{68} \mathrm{Ge}\right) / \mathrm{Ga}$-generators, ${ }^{68} \mathrm{Ga}$-citrate gained momentum as a PET radiotracer as it is a more advanced technique than ${ }^{67}$ Ga-citrate-SPECT. Rizzello et. al. described a method for the preparation of ${ }^{68} \mathrm{Ga}$-citrate for regular clinical use with a commercial semi-automatic labeling module (Eckert \& Ziegler FCON Pharmaitalia) [59]. Ayuob et. al. described the synthesis where ${ }^{68} \mathrm{GaCl}_{3}(3-5 \mathrm{mCi}$ in $150 \mu 1)$ in $0.6 \mathrm{M} \mathrm{HCl}$ was heated to dryness. A sodium citrate solution was added to the dried ${ }^{68} \mathrm{GaCl}_{3}$ and incubated at $50{ }^{\circ} \mathrm{C}$ for $10-15$ min followed by filtration through a 0.22 micron membrane (Scheme 2). The final $\mathrm{pH}$ of the solution was adjusted to 5.5-7 [60]. There is also a kit-based ${ }^{68}$ Ga-radiolabeling procedure available using ACD as a precursor [61]. 


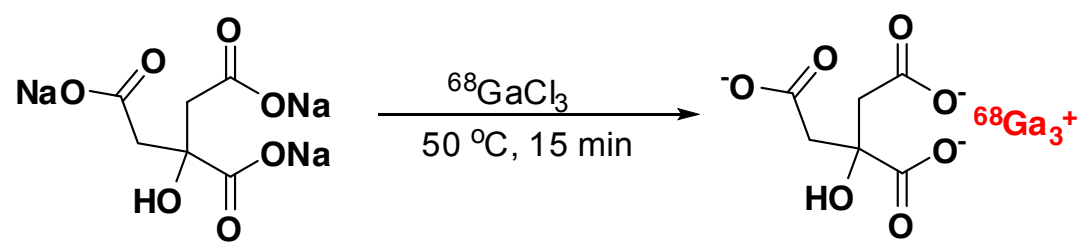

Scheme 2. Synthesis of ${ }^{68} \mathrm{Ga}$-Citrate 
Table 1 Commercially available probes for infection imaging

\begin{tabular}{|c|c|c|c|c|c|}
\hline Radiotracer class & Probe name & Targets & $\begin{array}{l}\text { Labelling } \\
\text { efficiency }\end{array}$ & Method & Reference \\
\hline \multirow{3}{*}{ Radiolabeled leukocytes } & ${ }^{111}$ In-oxine-leukocyte ${ }^{\#}$ & $\begin{array}{l}\text { Endocarditis, neurological infections, fever of } \\
\text { unknown origin, diabetic foot, inflammatory bowel } \\
\text { disease }\end{array}$ & $72.5 \pm 5.5 \%$ & SPECT & \multirow[t]{2}{*}[62]{} \\
\hline & ${ }^{99 \mathrm{~m}}$ Tc-HMPAO-leukocyte & $\begin{array}{l}\text { Imaging of infection and inflammation ( diabetic foot } \\
\text { prosthetic graft infection, abdominal sepsis, } \\
\text { osteomyelitis) }\end{array}$ & $44 \pm 13 \%$ & SPECT & \\
\hline & ${ }^{99 \mathrm{~m}} \mathrm{Tc}-$ Stannous colloids & $\begin{array}{l}\text { Spatial localization of infection for gram-positive } \\
\text { and gram negative bacteria }\end{array}$ & $>95 \%$ & SPECT & {$[27,28,31-33]$} \\
\hline \multirow{2}{*}{$\begin{array}{l}\text { Radiolabeled } \\
\text { antigranulocyte } \\
\text { antibodies }\end{array}$} & ${ }^{99 \mathrm{~m}}$ Tc-Besilesomab & $\begin{array}{l}\text { Pyrexia of unknown origin, appendicitis, acute } \\
\text { myocarditis and diabetic pedal osteomyelitis }\end{array}$ & -- & SPECT & {$[44]$} \\
\hline & ${ }^{99 \mathrm{~m}}$ Tc-Sulesomab & $\begin{array}{l}\text { Pyrexia of unknown origin and infection in soft } \\
\text { tissues }\end{array}$ & $4.5 \%$ & SPECT & {$[46]$} \\
\hline \multirow[t]{2}{*}{ Biomolecules } & ${ }^{18} \mathrm{~F}_{-} \mathrm{FDG}^{\#}$ & $\begin{array}{l}\text { Oncologic or cardiac indications, imaging infection } \\
\text { and inflammation }\end{array}$ & $50 \%$ & PET & {$[55]$} \\
\hline & ${ }^{67}$ Ga-citrate ${ }^{\#}$ & Detection of some acute infections and inflammation & -- & SPECT & {$[63-65]$} \\
\hline
\end{tabular}

\#) FDA approved 


\section{Novel imaging probes for direct, more specific imaging of bacterial infection}

Compounds having affinity towards a specific pathogen can be utilized for its direct in vivo imaging after being radiolabeled with a compatible radioisotope. In 2016, Auletta et al. systematically discussed the potential of quinolones, cephalosporins and siderophores as promising imaging agents for infection [66]. In a 2015 review, Tsopelos elaborated on compounds bearing potential towards scintigraphic detection of infection and inflammation [5]. Moreover, a few promising tracers show affinity towards bacteria such as ${ }^{11} \mathrm{In}-\mathrm{DPC} 11870,{ }^{11} \mathrm{In}-\mathrm{DTPA}-\operatorname{IgG}\left({ }^{14} \mathrm{C}\right),{ }^{111} \mathrm{In} /{ }^{99 \mathrm{~m}} \mathrm{Tc}$-DTPAhpc-IgG, ${ }^{18} \mathrm{~F}-\mathrm{DPA}-714,{ }^{99 \mathrm{~m}}$ Tc-PEG-liposomes, ${ }^{99 \mathrm{~m}} \mathrm{Tc}-\mathrm{HAS}$, labelled fMLFKs and labelled interleukins was explained by Tsopelos and we therefore excluded from this review. Furthermore, ${ }^{99 \mathrm{~m}} \mathrm{Tc}$ labelled bacteriophages were also omitted from this discussion. The following text highlights selected compound clusters that bear the largest potential to accomplish bacteria-selective tomographic imaging: i) antimicrobial peptides and ii) biomimetics.

\subsection{Antimicrobial peptides as bacteria-selective imaging probes}

Peptides are short chains of amino acids linked by amide bonds. These naturally occurring biomolecules are logical options for development as possible targeting vectors for PET tracers as they have unique characteristics such as; high target specificity and binding ability, low toxicity and immunogenicity and easy scale up production in the laboratory $[67,68]$. Generally, peptides containing less than 50 amino acids are considered for imaging tracers due to their molecular weight. These peptides are relatively small in size, facilitates rapid accumulation at the target site as well as lead to faster clearance from the recipient which would make them desirable candidates for PET molecular imaging probes [67]. 
In general, naturally occurring peptides are most suited for designing peptide-based PET tracers; as they play a vital role in certain physiological conditions by mediating via their high-affinity, specific and massively overexpressed receptors [69]. However, various plasma-containing proteases and peptidases lead to rapid degradation of some of these compounds resulting in a shorter pharmacological half-life and decreased target availability. Thus, to increase the in vivo stability of naturally occurring peptides, these compounds require molecular engineering at the amino acid residues that are involved in degradation without compromising the most desired biological activity. Till date, a number of researchers have described various approaches to modify amino acid residues to increase the efficiency and stability of peptides. These approaches include peptide bond substitution, $\mathrm{N}$ - and C-terminus acetylation, sidechain and unnatural amino acid introduction, suitable D-amino acid incorporation and amino alcohol utilization. In addition, suitable hydrophilic and/or lipophilic amino acids can also be introduced to modify the permeability of the peptide without compromising the binding efficiency [70-72].

The success of PET probes development is based on identification of its molecular target and characterization of its biological role. Some of the targets best studied for the development of peptide-based PET probes are integrin, somatostatin and gastrinreleasing peptide receptors [73-81]. Moreover, antimicrobial peptides (AMP) are also trending for developing PET tracers for infection imaging because of their direct involvement in the innate immune system and their ability to bind selectively to pathogenic bacteria or yeast $[7,68]$. AMPs are synthesized by various cells; however, regardless of the origin, these peptides share a few common characteristics as they are membrane active, positively charged and amphipathic [82]. Due to their cationic 
properties, it is believed that AMPs have strong electrostatic affinity towards the negatively charged bacterial cell wall while having relatively lower attraction to mammalian cells which are less negatively charged [7, 83]. Peptides are becoming popular as infection imaging probes because of their ability to accumulate at infection foci as well as a lack of cytotoxicity in the recipient [84]. Even though, peptides have been studied extensively as radiotracers for various physiological conditions; there is only a handful of AMPs evaluated for infection imaging [85].

\subsubsection{Ubiquicidin (UBI)}

Ubiquicidin is a $6.7 \mathrm{kDa}$ polypeptide comprising of 59 amino acid residues. This peptide was first identified from a macrophage cell line of mouse and has antibacterial effects on Salmonella typhimurium and Lysteria monocytogenes. Subsequently it was also isolated from numerous organisms, including human. This peptide has a structure that is homologous to the murine ribosomal subunit S30 [86]. Brouwer et al., in 2006, synthesized several fragments of the ${ }^{99 \mathrm{~m}} \mathrm{Tc}$ labeled UBI and studied the in vitro bacterial sensitivity as well as selectivity. They also found sufficient accumulation of the fragments ${ }^{99 m}$ Tc-KVAKQEKKKKKTGRAKRR (UBI-18-35) and ${ }^{99 m}$ TcTGRAKRRMQYNRR (UBI29-41) around the infected site in mouse models for SPECT imaging [87]. These peptides were synthesized on solid phase via 9fluorenylmethoxycarbonyl (Fmoc) chemistry. PyBOP was employed as the coupling reagent along with the base 4-methylmorpholine (NMM) in NMP for the coupling [87]. Direct radiolabeling was carried out by adding $\mathrm{SnCl}_{2}$ and sodium pyrophosphate in saline to a stock solution of the peptide. Thereafter, $\mathrm{KBH}_{4}$ in $0.1 \mathrm{M} \mathrm{NaOH}$ and ${ }^{99 m}$ Tc-sodium pertechnetate solutions were added to the mixture respectively. The reaction was carried out for $1 \mathrm{hr}$ at room temperature (Scheme 3) [87]. 


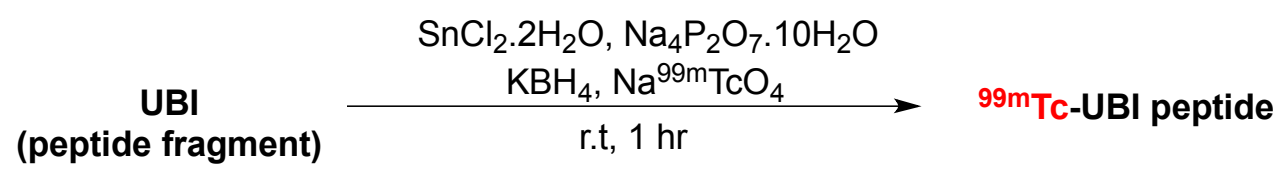

Scheme 3. Synthesis of ${ }^{99 \mathrm{~m}}$ Tc labeled UBI fragment

Over the years ${ }^{99 m}$ Tc-UBI(29-41) fragments were found to be specific as well as selective towards both gram positive and gram negative bacteria along with the multidrug resistant strains $[88,89][90,91]$ [92]. ${ }^{99 m}$ Tc-UBI (29-41) may attach the radioisotope at Lys and Arg residues of the peptide. This did not allow for the peptide to retain its natural configuration $[93,94]$. The radiolabeled UBI fragment ${ }^{99 \mathrm{~m}} \mathrm{Tc}-$ UBI(29-41) was first administered in human subjects in 2004 for studying its pharmacokinetic properties in a clinical trial on patients with soft-tissue, prosthesis or suspected bone infections. The results revealed high specificity, selectivity and accuracy without any significant adverse effects [95]. Recently, fluorine-18 was used to radiolabel UBI(29-41) for the purpose of PET imaging. However in this study, the ${ }^{18}$ F-UBI(29-41) did not confirm specificity towards S. aureus in vivo [96] and there was also significant defluorination. Concerning the radiosynthesis, to a mixture of Kryptofix and $\mathrm{K}_{2} \mathrm{CO}_{3} / \mathrm{K}_{2} \mathrm{C}_{2} \mathrm{O}_{4}$, fluorine-18 was added followed by evaporation under vacuum in the reactor. Thereafter, reduction of the compound was carried out by ethyl 4-(trimethylammonium)benzoate trifluoromethanesulfonate in DMSO. The reaction was heated at $95{ }^{\circ} \mathrm{C}$ for 6 min followed by the distillation of the product in a $0.5 \mathrm{M}$ $\mathrm{NaOH}$ solution. The product was again hydrolysed for $2 \mathrm{~min}$ at $50{ }^{\circ} \mathrm{C}$ in the reactor after rinsing it with $5 \%$ acetic acid and water. $0.5 \mathrm{M} \mathrm{HCl}$ was then added to make the product $4-{ }^{18}$ F-fluorobenzoic acid which was eluted through a Lichrolut EN cartridge. A purified solution of this product was mixed with 4-(dimethylamino)-pyridine (DMAP) and dried in the reactor. Subsequently, $N, N^{\prime}$-disuccinimidylcarbonate (DSC, 
in acetonitrile) was added and heated at $95{ }^{\circ} \mathrm{C}$ for $7 \mathrm{~min}$ followed by cooling to $35^{\circ} \mathrm{C}$. This crude $N$-succinimidyl-4-[ $\left.{ }^{18} \mathrm{~F}\right]$ fluorobenzoate was eluted through a Lichrolut EN cartridge followed by HPLC purification and again eluted through a Lichrolut EN cartridge. Finally, the $N$-succinimidyl-4-[ $\left[{ }^{18} \mathrm{~F}\right]$ fluorobenzoate (in DMF) was mixed with UBI $29-41$ in $0.1 \mathrm{M}$ boraxbuffer $(\mathrm{pH} 8.5)$ and left to react for $10 \mathrm{~min}$ at room temperature in a ultrasound bath. The radiolabeled $4-\left[{ }^{18} \mathrm{~F}\right]$ fluoro-benzoyl-ubiquicidin 29-41 ( ${ }^{18}$ F-UBI29-41) was HPLC purified followed by elution through a C18 cartridge (Scheme 4) [97].

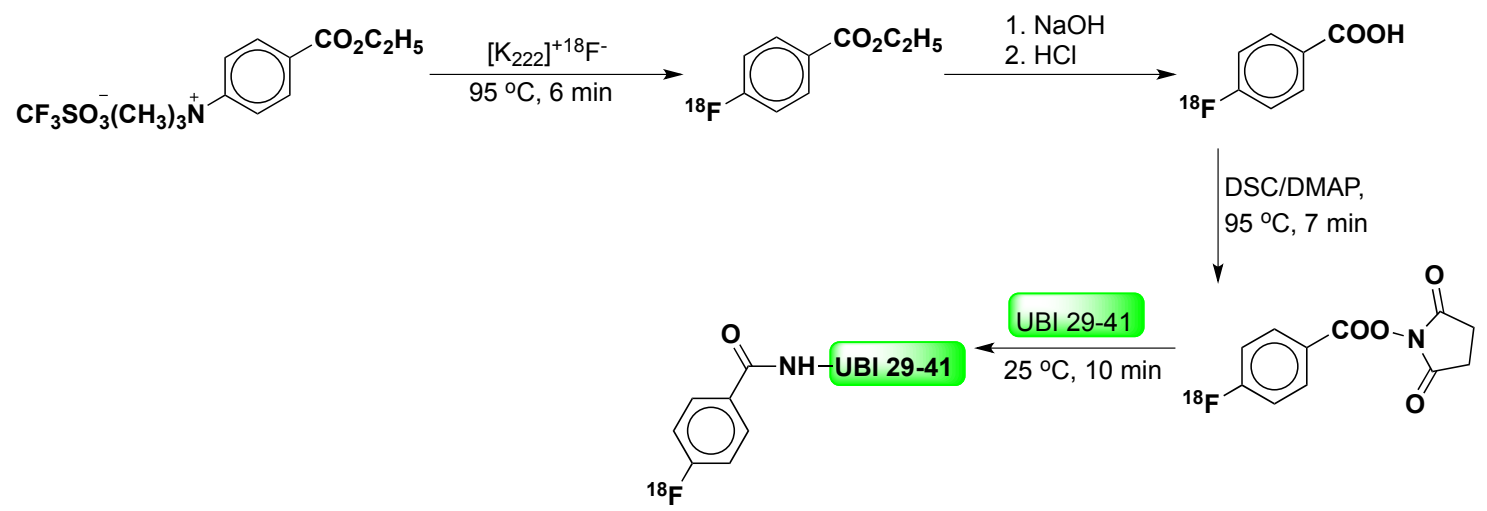

Scheme 4. Synthesis of [18F]UBI 29-41

${ }^{68}$ Ga-NOTA-UBI(29-41) showed specificity towards $S$. aureus in a rabbit model and was able to distinguish infection from sterile inflammation [98]. For the design of the UBI containing the ${ }^{68} \mathrm{Ga}$ radiotracer, a chelator was envisaged. In this case the peptide was synthesized on resin and conjugated with 1,4,7-triazacyclononane-1,4,7-triacetic acid (NOTA). The NOTA conjugation was carried out by functionalizing the amino terminus of the peptide with bromoacetic acid and diisopropylcarbodiimide (DIC) in dichloromethane. The bromine was then displaced with excess 1,4,7-triazacyclononane and trimethylamine (TEA) in acetonitrile. tert-Butyl 2-bromoacetate was added to the remaining secondary amines of triazacyclononane ring [98] followed by full deprotection and cleavage from the resin (Scheme 5). 


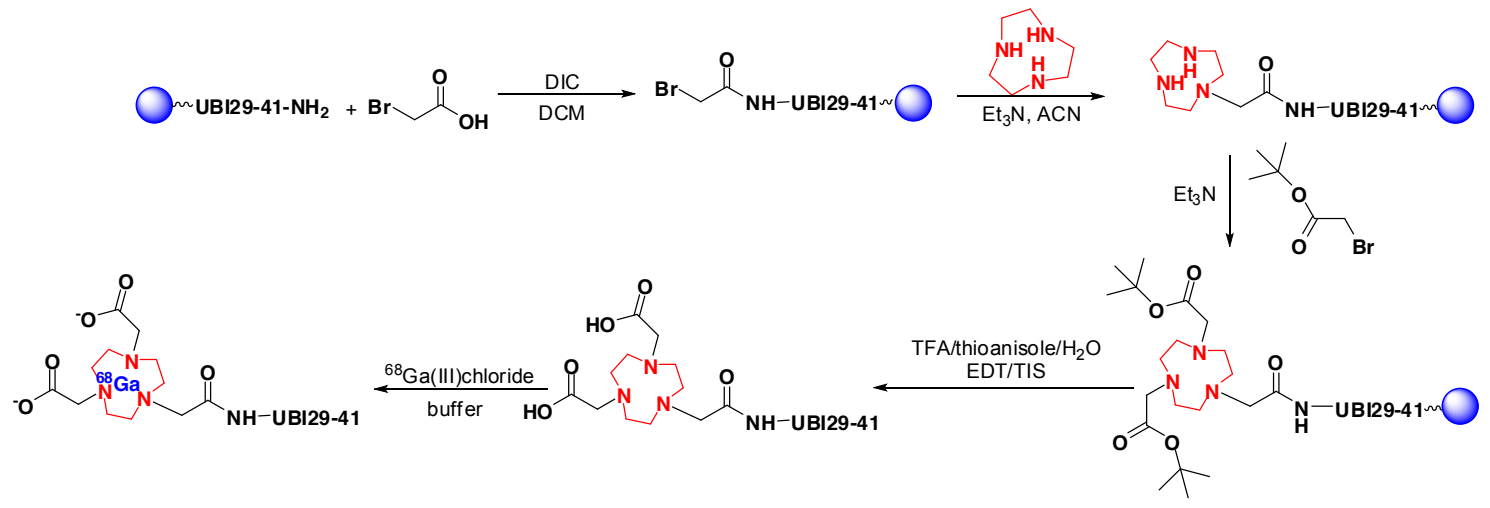

Scheme 5. Synthesis of ${ }^{68}$ Ga-NOTA-UBI29-41 complex

\subsubsection{Human neutrophil peptide (HNP)}

Neutrophils are integral components of the immune system and play a vital role in protecting the host from microbial infections by producing neutrophil peptides. These cationic single chain peptides are rich in arginine and cysteine. Neutrophil peptides are of about $3.5 \mathrm{kDa}$ and designated as defensins [99]. HNP-1 (ACYCRIPACIAGERRYGTCIYQGRLWAFCC with disulfide bridges: 2-30; 4-19; 9-29), HNP-2 (CYCRIPACIAGERRYGTCIYQGRLWAFCC with disulfide bridges: 1-29, 3-18, 8-28), HNP-3 (DCYCRIPACIAGERRYGTCIYQGRLWAFCC with disulfide bridges: 2-30; 4-19; 9-29) and HNP-4 (VCSCRLVFCRRTELRVGNCLIGGVSFTYCCTRV with disulfide bridges: 2-30; 4-19; 9-29) are the four neutrophil peptides identified in human [100, 101]. HNP-1, HNP-2 and HNP-3 comprise of 29 common amino acid residues which represents 99\% sequence homology while HNP-4 shares only $32 \%$ homology with the others [101, 102]. It is postulated that defensin interact with deoxyribonucleic acids, which in turn leads to cell death [103]. Mouse infection model studies revealed the potential use of HNP-1 as a therapeutic agent for bacteria including M. tuberculosis [104]. Biodistribution and potential antimicrobial evaluation of ${ }^{99 \mathrm{~m}} \mathrm{Tc}$ labelled HNP-1 in $K$. 
pneumoniae and S. aureus infected (peritoneal and intramuscular infections) swiss mice confirms the accumulation of this tracer in the infection sites [105]. In this study, Welling et. al. isolated HNP-1 from human neutrophil, which was then purified by HPLC [105]. HNP-1 in sodium phosphate buffer (Na-PB) was then mixed with a sterile solution of stannous pyrophosphate and immediately reduced with $\mathrm{KBH}_{4}$ dissolved in a $\mathrm{NaOH}$ solution. Finally, the solution was stirred for 30 min with ${ }^{99 \mathrm{~m}} \mathrm{Tc}$ sodium pertechnetate solution to yield radiolabeled HNP-1 [105-107]. Raj et. al., in 2000, described a method for the solid phase synthesis of HNP-1 on Wang resin using Fmoc protected amino acids [108]. DIC in the presence of HOBt was used as the coupling reagent where a mixture of DCM and DMF $(50 \% \mathrm{v} / \mathrm{v})$ served as the solvents. Fmoc deprotection was carried out using $25 \%$ solution of piperidine in DMF and the peptide was cleaved from the resin using 90\% TFA in DCM containing dimethyl sulphide $(2.5 \%)$ and thioanisole $(2.5 \%)$ [108].

\subsubsection{Neutrophil elastase inhibitor peptide}

The protease, neutrophil elastase is secreted by the activated neutrophils when triggered due to inflammation at the infection foci. This $29 \mathrm{kDa}$ antimicrobial peptide is released upon internalization [109] and rapidly inhibited by $\alpha-1$ trypsin inhibitor [110]. A peptide library was constructed based on wild-type bovine pancreatic trypsin inhibitors with the help of phage display technology. Screening of these peptides on immobilized human neutrophil elastase, revealed EPI-HNE-2 (EAEARPDFCLEPPYTGPCIAFFPRYFYNAKAGLCQTFVYGGCMGNG--NNFKSAEDCMRTCGGA) as the most potent and specific inhibitor $[111,112]$. EPI-HNE-2 radiolabeled with ${ }^{99 \mathrm{~m}} \mathrm{Tc}$ was studied in monkeys for inflammation/infection imaging. Based on the outcome, the bacterial specificity of the tracer was not clear, however, it did accumulate within 
areas with inflammations and infections [113]. EPI-HNE-2 can be radiolabeled with ${ }^{99} \mathrm{~m}$ Tc using the bifunctional chelator molecule NHS-MAG3. Peptide-NHS-MAG3 conjugation was carried out by a dropwise chelator addition (in DMF) to a solution of EPI-HNE-2 in 0.1 M HEPES buffer ( $\mathrm{pH} 8.0)$. The solution was then left for $1 \mathrm{~h}$ undisturbed and finally the conjugated peptide was purified on a P-4 column (Bio-Rad, Melville, NY). To the purified conjugated peptide in $0.25 \mathrm{M}$ ammonium acetate buffer, sodium tartrate (in $0.5 \mathrm{M}$ sodium bicarbonate), ammonium acetate and ammonium hydroxide was added followed by a solution of stannous chloride (in $10 \mathrm{mM} \mathrm{HCl}$ ). Finally, ${ }^{99 \mathrm{~m}}$ Tc-pertechnetate was mixed in and incubated for $1 \mathrm{hr}$ at room temperature for the completion of the reaction (Scheme 6). The $\mathrm{pH}$ was adjusted to 7.6 and purified on a P-4 column [114].

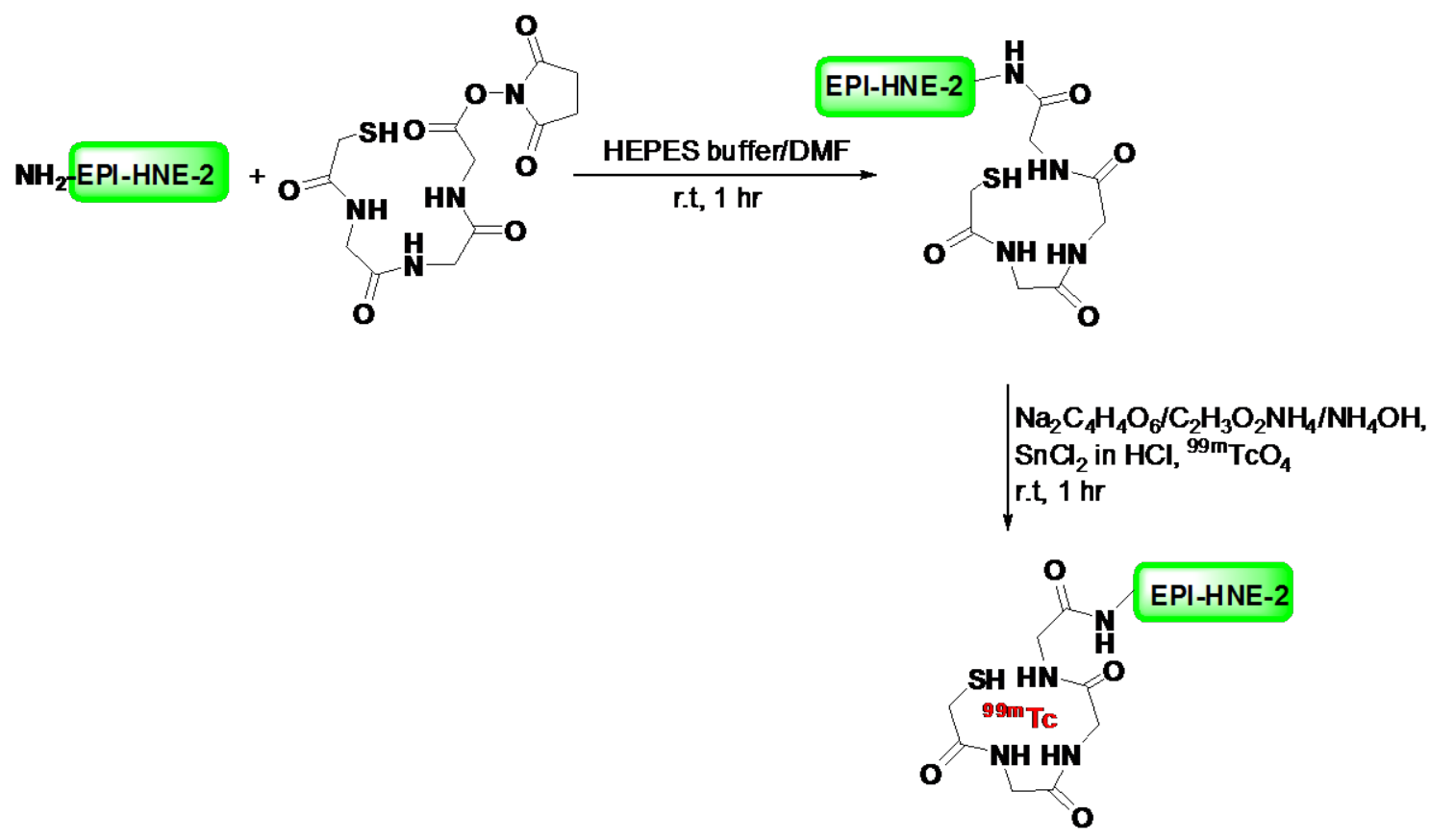

Scheme 6. Synthesis of ${ }^{99 \mathrm{~m}} \mathrm{Tc}-\mathrm{MAG} 3-\mathrm{EPI}-\mathrm{HNP} 2$ 


\subsubsection{Human $\beta$-defensin (HBD)}

Defensins are the first line of the defense mechanism of the human immune system and the $\beta$ defensins are one class that are of epithelial tissue origin $[115,116] . A 4 \mathrm{kDa}$ peptide, human $\beta$ defensin-3 (HBD-3), shows a broad range of antimicrobial activity including for both gram-positive and -negative bacteria [117-119]. HBD-3 (GIINTLQKYYCRVRGGRCAVLSCLPKEEQIGKCSTRGRKCCRRKK) was successfully radiolabeled with ${ }^{99 \mathrm{~m}} \mathrm{Tc}$ and was able to distinguish between infection and sterile inflammation in a mouse model previously infected with S. aureus [115]. A cationic complex $\left[{ }^{99 \mathrm{~m}} \mathrm{Tc}\left(\mathrm{H}_{2} \mathrm{O}\right)_{3}(\mathrm{CO})_{3}\right]^{+}$was used to label the recombinant HBD-3 [115]. $\left[{ }^{99 \mathrm{~m}} \mathrm{Tc}\left(\mathrm{H}_{2} \mathrm{O}\right)_{3}(\mathrm{CO})_{3}\right]^{+}$can be synthesized through the reduction of $\left[{ }^{99 \mathrm{~m}} \mathrm{TcO}_{4}\right]^{-}$in saline $\left(0.9 \% \mathrm{NaCl} / \mathrm{H}_{2} \mathrm{O}\right)$ by $\mathrm{NaBH}_{4}$. This reaction required heating at $75{ }^{\circ} \mathrm{C}$ and flashed with carbon monoxide [120]. The solution was cooled and adjusted to $\mathrm{pH} 8.0$

with $\mathrm{HCl}$. The peptide, dissolved in water, was added to the solution containing $\left[{ }^{99 \mathrm{~m}} \mathrm{Tc}\right.$ $\left.\left(\mathrm{H}_{2} \mathrm{O}\right)_{3}(\mathrm{CO})_{3}\right]^{+}$and left for $60 \mathrm{~min}$ to react at room temperature (Scheme 7). The radiolabeled HBD-3 was finally purified by gel chromatography using a Sephadex G-2 column [115].

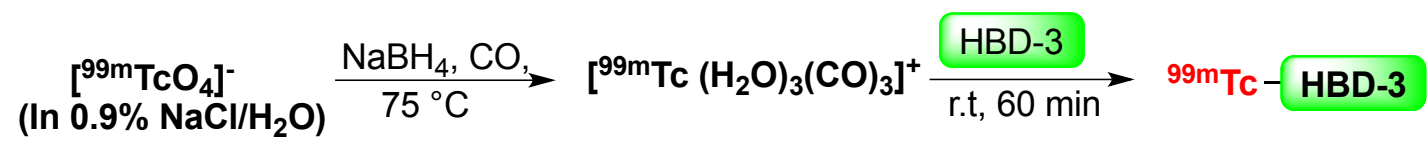

Scheme 7. Synthesis of ${ }^{99 m}$ Tc-HBD-3

\subsubsection{Human lactoferrin-derived peptide ( $h L F)$}

Lactoferrin (PDB ID: 1FCK), a member of the transferrin family, is an $80 \mathrm{kDa}$ ironbinding protein $[121,122]$. This glycoprotein is secreted by mammalian mucosal epithelial cells including those of human [122]. Lactoferrin is found in milk, urine, bile, nasal and bronchial secretions, gastrointestinal fluids, semen, vaginal fluids, tears 
and saliva [123-125]. The defensive properties of this peptide includes antimicrobial (including antibiotic-resistant bacteria), anti-inflammatory and anticancer properties due to immune modulator activities $[122,126]$. An eleven amino acid containing cation-rich sequence (1-11: GRRRRSVQWCA) from the N-terminus of human lactoferrin was reported to be active against bacteria and also showed immune modulatory compound behaviour [126, 127]. Welling et. al. in 2000, studied various fragments of UBI and hLF for their bacterial specificity and selectivity; concluding that the former is more favourable for infection detection [92]. For this study the peptide sequences were synthesized on solid phase employing Fmoc chemistry with PyBOP/NMM in NMP as coupling conditions with Fmoc deprotection using piperidine [128]. For radiolabelling, the synthesized peptide solutions (in $0.01 \mathrm{M}$ of acetic acid $\mathrm{pH}$ 4) were mixed with stannous pyrophosphate followed by immediate addition of $\mathrm{KBH}_{4}$ (in $0.1 \mathrm{M} \mathrm{NaOH}$ ). Finally a ${ }^{99 \mathrm{~m}} \mathrm{Tc}$-sodium pertechnetate solution obtained from a ${ }^{99 m}$ Tc generator was added and the $\mathrm{pH}$ was adjusted to between 5-6. One hour of gentle stirring was carried out for completion of the reaction (Scheme 8) [92].

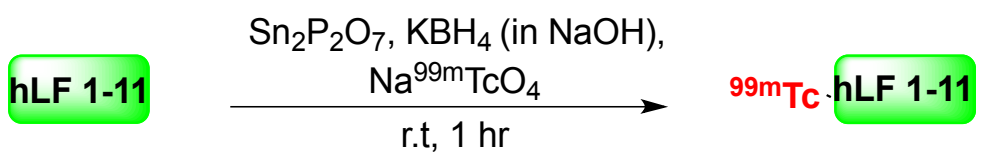

Scheme 8. Synthesis of ${ }^{99 m}$ Tc-hLF 1-11 
Table 2 Antimicrobial peptides for bacterial imaging

\begin{tabular}{|c|c|c|c|c|c|c|}
\hline $\begin{array}{l}\text { Antimicrobial } \\
\text { peptide name* }\end{array}$ & $\begin{array}{l}\text { Radioisoto } \\
\text { pe }\end{array}$ & 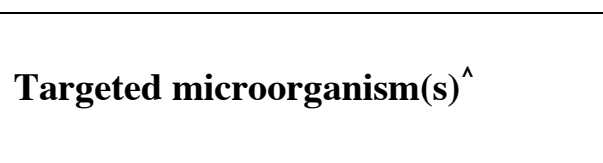 & T/NT ${ }^{\text {a) }}$ ratio & $\begin{array}{l}\text { Labelling } \\
\text { efficiency }\end{array}$ & Method & Reference \\
\hline UBI29-41 & $\begin{array}{l}{ }^{99 \mathrm{~m}} \mathrm{Tc},{ }^{18} \mathrm{~F}, \\
{ }^{68} \mathrm{Ga}\end{array}$ & $\begin{array}{l}\text { S. aureus, E. coli, C. albicans and } A \text {. } \\
\text { fumigatus }\end{array}$ & $2.2-4.6$ & $>95 \%-99.2 \%$ & $\begin{array}{l}\text { Scintigraphy, } \\
\text { PET, }\end{array}$ & {$[89,96,98]$} \\
\hline HNP-1 & ${ }^{99 \mathrm{~m}} \mathrm{Tc}$ & K.pneumonia, S. aureus, M.tuberculosis & $1.5-3.5$ & $88 \%$ & Scintigraphy & [105] \\
\hline EPI-HNE-2 & ${ }^{99 \mathrm{~m}} \mathrm{Tc}$ & -- & $0.3-2$ & $54 \%$ & Scintigraphy & {$[113,114]$} \\
\hline HBD-3 & ${ }^{99 \mathrm{~m}} \mathrm{Tc}$ & S. aureus, K. pneumoniae and E. coli & 3 & $40 \%-50 \%$ & Scintigraphy & [115] \\
\hline hLF & ${ }^{99 \mathrm{~m}} \mathrm{Tc}$ & K. pneumonia, S. aureus & $>2.4$ & $92 \%$ & Scintigraphy. & {$[92]$} \\
\hline
\end{tabular}

*) UBI29-41:ubiquicidin peptide fragment 29-41;HNP-1: human neutrophil peptide 1; EPI-HNE-2: Neutrophil elastase inhibitor peptide 2;

HBD-3: human $\beta$ defensin-3; hLF: human lactoferrin-derived peptide 1-11

) S. aureus: Staphylococcus aureus; E. coli: Escherichia coli; C. albicans: Candida albicans; A. fumigatus: Aspergillus fumigatus; K. pneumonia: Klebsiella pneumonia; M. tuberculosis: Mycobacterium tuberculosis

a) $\mathrm{T} / \mathrm{NT}=$ Target$/$ Non Target 


\subsection{Biomimetics}

Biomimetics are a group of compounds that are deliberate to exploit unique bacterial targets. These compounds are trapped upon internalization either because of their interaction with the cellular macromolecules or by acting as a substrate for the enzyme of the pathogen. This intracellular mechanism in turn promises for signal amplification and allows for imaging of the pathogen.

\subsubsection{Antibiotics/Antimicrobial drugs}

Antibiotics are potential candidates for tomographic imaging because of their characteristic specificity towards bacteria. ${ }^{99 \mathrm{~m}}$ Tc-ciprofloxacin (Figure 1) is the first and most widely studied radiolabeled antibiotic [129-132]. ${ }^{99 \mathrm{~m}} \mathrm{Tc}-$ fluoroquinolones $\left({ }^{99 \mathrm{~m}}\right.$ Tc-norofloxacin, ${ }^{99 \mathrm{~m}} \mathrm{Tc}$-sparfloxacin) were subsequently explored as a second line of antibiotic based radiotracer. Evidently, the potential of other antibiotics has been investigated as imaging agents; for example, intracellular targets $\left({ }^{99 \mathrm{~m}} \mathrm{Tc}\right.$-kanamycin, ${ }^{99 \mathrm{~m}}$ Tc-cefuroxineaxetil, ${ }^{99 \mathrm{~m}} \mathrm{Tc}$-cefoperazone, ${ }^{99 \mathrm{~m}} \mathrm{Tc}$, -ceftizoxine $)$, cell wall $\left({ }^{99 \mathrm{~m}} \mathrm{Tc}-\right.$ vancomycin, ${ }^{99 \mathrm{~m}} \mathrm{Tc}$-alafosfalin, ${ }^{99 \mathrm{~m}} \mathrm{Tc}$-ceftizoxine) and specific mycobacterial targets $\left({ }^{11} \mathrm{C} /{ }^{99 \mathrm{~m}}\right.$ Tc-rifampicin, ${ }^{11} \mathrm{C} /{ }^{18} \mathrm{~F} /{ }^{99 \mathrm{~m}} \mathrm{Tc}$-isoniazid and ${ }^{99 \mathrm{~m}} \mathrm{Tc}$-ethambutol).<smiles></smiles>

Figure 1. Structure for ${ }^{99 \mathrm{~m}} \mathrm{Tc}$-ciprofloxacin 


\subsubsection{Aminoglycoside}

Aminoglycosides are polycationic entities which manifests its effect by ribosomal blockade, misreading in translation, membrane damage, and irreversible uptake of the antibiotic [133, 134]. Labelling of kanamycin, streptomycin and gentamicin can be achieved with the reducing agent $\mathrm{SnCl}_{2} \cdot 2 \mathrm{H}_{2} \mathrm{O}$. A solution of $\mathrm{SnCl}_{2}$ was added to a solution of kanamycin/streptomycin/gentamicin and the $\mathrm{pH}$ adjusted. To that mixture, ${ }^{99} \mathrm{TcO}_{4}{ }^{-}$was added and the reaction was carried out at room temperature (Scheme 9) [135-137]. For the labeling of tobramycin, the same reducing agent was utilised but with the exception that the $\mathrm{SnCl}_{2} \cdot 2 \mathrm{H}_{2} \mathrm{O}$ was dissolved in $\mathrm{HCl}$ and then mixed with a solution of $\mathrm{NaOH}: \mathrm{NaHCO}_{3}$ and $\mathrm{Na}^{99 \mathrm{~m}} \mathrm{TcO}_{4}$ under a blanket of nitrogen gas [138].

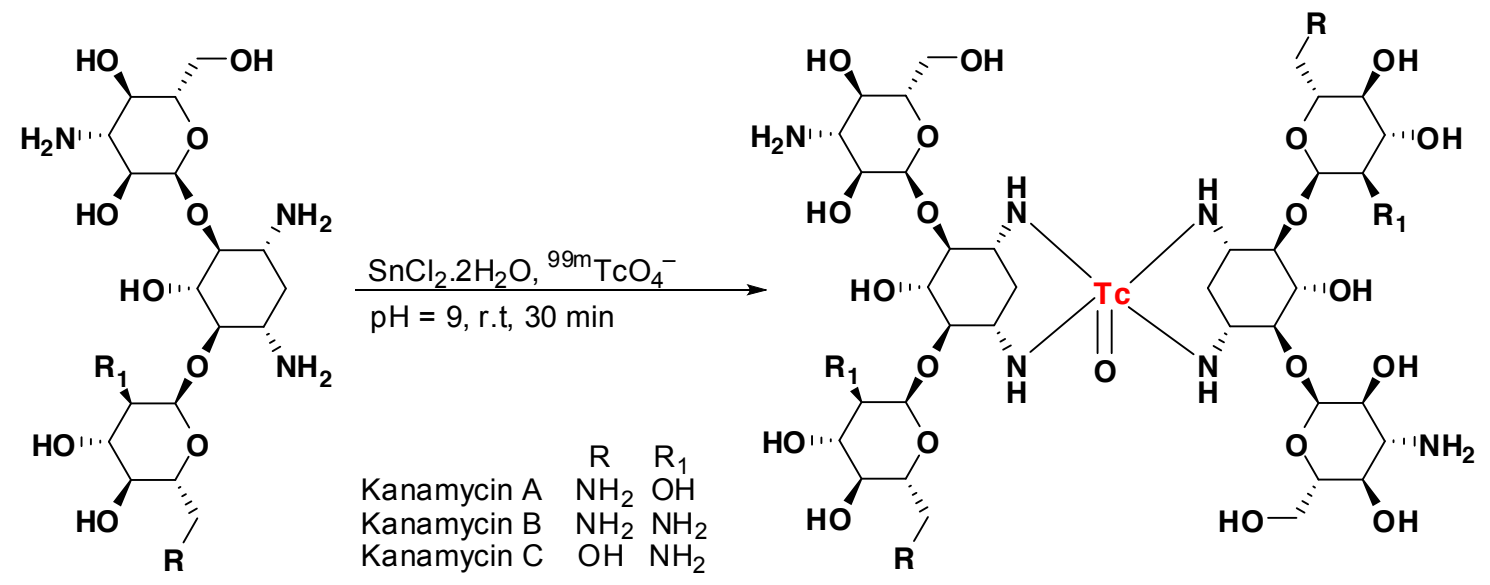

Scheme 9. Synthesis of ${ }^{99 \mathrm{~m}}$ Tc-Kanamycin

\subsubsection{Amino-penicillin $3^{\text {rd }}$ generation}

As a member of the amino-penicillin group of drugs, amoxicillin acts against grampositive and gram negative bacteria by interfering with the cell wall muco-peptide biosynthesis [139]. ${ }^{99 \mathrm{~m}} \mathrm{Tc}$ - amoxicillin has demonstrated to be taken up by E. coli infected and inflamed thigh muscles in an animal model [140]. Amoxicillin was radiolabeled with ${ }^{99 \mathrm{~m}} \mathrm{Tc}$ by Ozdemir et. al. in 2015 [140]. They demonstrated the use of both the reducing agent and antioxidant for labeling amoxicillin. Amoxicillin was 
mixed with stannous chloride under an atmosphere of nitrogen and radiolabeling was initiated by adding freshly eluted ${ }^{99 \mathrm{~m}} \mathrm{Tc}$. The optimization of the of labeling efficiency and stability of the complex was judged by addition of varying concentrations of the reducing agent (stannous chloride and stannous tartrate) and the antioxidant (ascorbic acid) (Scheme 10) [140].
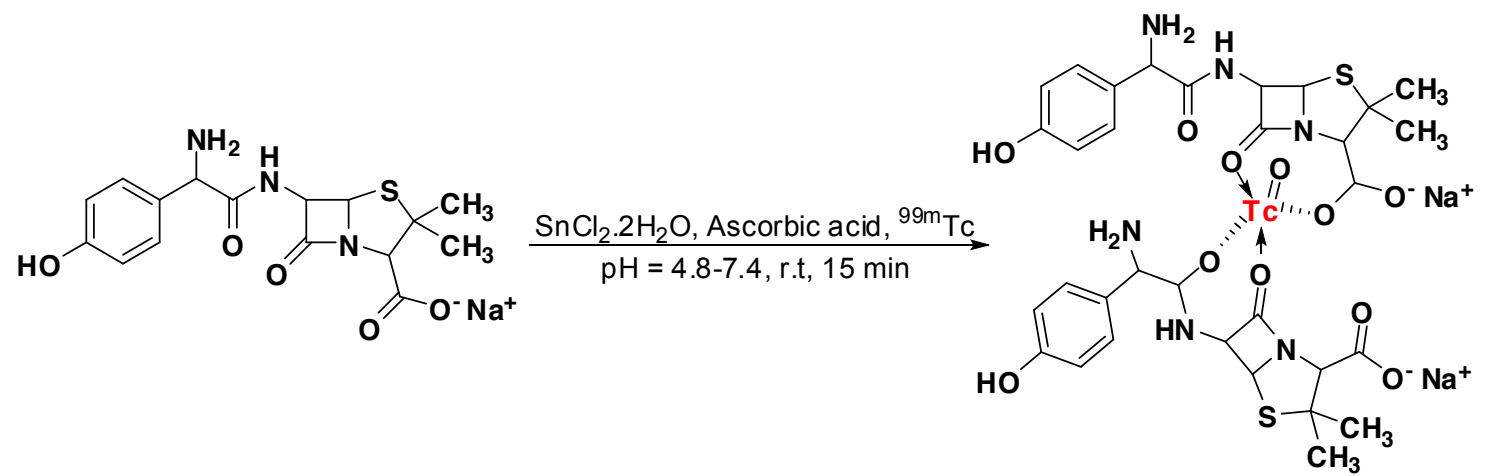

Scheme 10. Synthesis of ${ }^{99 m}$ Tc- amoxicillin

\subsubsection{Cephalosporins}

The $\beta$-lactam group of antibiotics compromises the bacterial cell wall integrity by hampering the peptidoglycan layer synthesis [5]. A few of the cephalosporins that have been radiolabeled so far are cefuroxine, ceftizoxine, ceftriaxone, cefotaxime, cefoperazone and cefepime. These antibiotics complexed with ${ }^{99 \mathrm{~m}} \mathrm{Tc}$ showed potential advantages in distinguishing infection ( $S$. aureus and/or E. coli) from aseptic inflammation foci in various animal models [141-146]. Cephalosporins such as cefuroxine axetil, ceftriaxone and cefepime were radiolabelled in the presence of the reducing agent stannous chloride. The compound was dissolved in sterile water, mixed with a solution of $\mathrm{SnCl}_{2} \cdot 2 \mathrm{H}_{2} \mathrm{O}$ and the $\mathrm{pH}$ was adjusted. Finally $\mathrm{Na}^{99 \mathrm{~m}} \mathrm{TcO}_{4}$ was added to the solution and incubated at room temperature [141-143]. However in the case of ceftriaxone, the mixture was refluxed before incubation at room temperature (Scheme 11) [142]. 

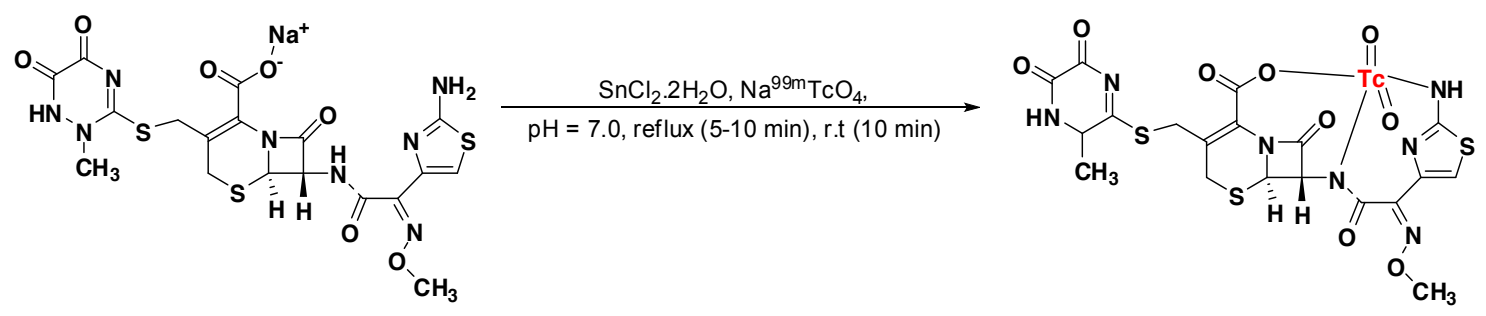

Scheme 11. Synthesis of ${ }^{99 m}$ Tc-ceftriaxone

For radiolabeling ceftizoxima and cefotaxime, the compounds were dissolved in water and sodium dithionate (dissolved in $0.5 \% \mathrm{NaHCO}_{3}$ ) was added followed by ${ }^{99 \mathrm{~m}} \mathrm{Tc}$ pertechnetate. The solutions were heated to $100{ }^{\circ} \mathrm{C}$ before maintaining it at room temperature $[144,145]$.

In the case of cefoperazone, the antibiotic was mixed with a tin(II) solution and the $\mathrm{pH}$ was adjusted. Finally, freshly eluted ${ }^{99 \mathrm{~m}}$ Tc-activity was added to the mixture and incubated at room temperature with vigorous shaking until completion of the reaction [146].

\subsubsection{Glycopeptides}

Teicoplanin and vancomycin fall under the glycopeptide group of antibiotics with their mode of action by interfering with the peptidoglycan layer synthesis [147]. Radiolabeled ${ }^{99 \mathrm{~m}}$ Tc-teicoplanin was shown to accumulate in high concentration (in $2 \mathrm{~h}$ ) at the site of $S$. aureus in infected mice [148]. In another study, ${ }^{99 \mathrm{~m}} \mathrm{Tc}$-vancomycin also showed similar affinity towards $S$. aureus infection foci [149]. Glycopeptides, vancomycin and teicoplanin, were radiolabeled in the presence of $\mathrm{SnCl}_{2} \cdot 2 \mathrm{H}_{2} \mathrm{O}$. Briefly, the glycopeptide was mixed with $\mathrm{SnCl}_{2} \cdot 2 \mathrm{H}_{2} \mathrm{O}$ and the $\mathrm{pH}$ was adjusted. The solution was incubated at room temperature after addition of a freshly prepared solution of ${ }^{99 \mathrm{~m}} \mathrm{TcO}_{4}{ }^{-}[148,149]$. 


\subsubsection{Lincosamide}

Lincosamide binds to the 50S subunit of bacterial ribosomes and blocks the exit of the newly formed peptide [150]. The lincosamide group of antibiotics, namely clindamycin and lincomycin, were radiolabeled in the similar way as described above. ${ }^{99 m}$ Tc-lincomycin was studied in a rabbit model, which showed significant accumulation of this labeled antibiotic in S. aureus infected thigh [151]. In another study ${ }^{99 \mathrm{~m}}$ Tc-clindamycin showed its potential to distinguish infection from sterile inflammation in both rat as well as in rabbit models [152]. Antibiotics were mixed with $\mathrm{SnCl}_{2} \cdot 2 \mathrm{H}_{2} \mathrm{O}$ and the $\mathrm{pH}$ was adjusted. Ascorbic acid was added to the reaction mixture as a stabilizer followed by freshly eluted ${ }^{99 \mathrm{~m}} \mathrm{TcO}_{4}{ }^{-}[151,152]$.

\subsubsection{Macrolides}

Macrolides, though structurally different from lincosamide antibiotics share the same mechanism of action by also binding to the 50S subunit of the bacterial ribosome [150]. Erythromycin, clarithromycin and azithromycin, as the group-representing compounds, were successfully radiolabeled with ${ }^{99 \mathrm{~m}} \mathrm{Tc}$. These probes were subsequently studied in a mouse model to evaluate their potential as radiopharmaceutics. In these studies, radiolabeled ${ }^{99 \mathrm{~m}} \mathrm{Tc}$-clarithromycin and ${ }^{99 \mathrm{~m}} \mathrm{Tc}$-azithromycin significantly accumulated in the $S$. aureus infected thigh compared to the uninfected contralateral thigh. Solutions of the macrolide class of antibiotics (erythromycin, clarithromycin and azithromycin) were mixed with $\mathrm{SnCl}_{2} \cdot 2 \mathrm{H}_{2} \mathrm{O}$ and $\mathrm{pH}$ was adjusted with $\mathrm{HCl} .{ }^{99 \mathrm{~m}} \mathrm{TcO}_{4}{ }^{-}$was added to the mixture and the reaction was carried out at room temperature [153-155].

\subsubsection{Nitrofurans}

The mode of action for nitrofurans is by targeting and damaging the deoxyribonucleic acid (DNA) of the pathogen in its reduced form. Nitrofuran is reduced by the 
flavoproteins of the pathogen into reactive intermediates which in turn affects the pyruvate metabolism, respiration and ribosomal DNA [156]. Nitrofurantoin was successfully radiolabeled with ${ }^{99 \mathrm{~m}} \mathrm{Tc}$ for potential imaging of $E$. coli. It was labeled with sodium pertechnetate in the presence of stannous chloride (Scheme 12) [157].

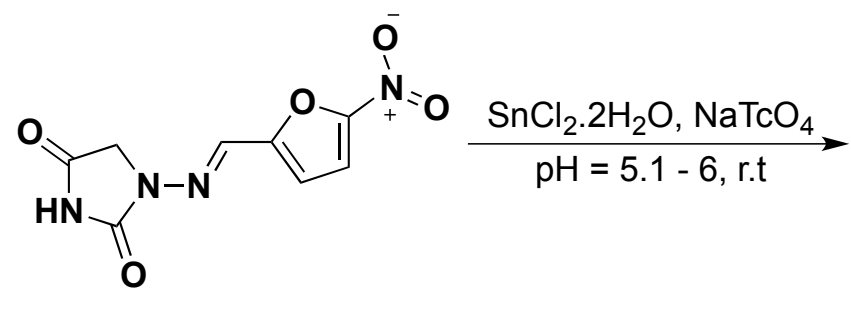

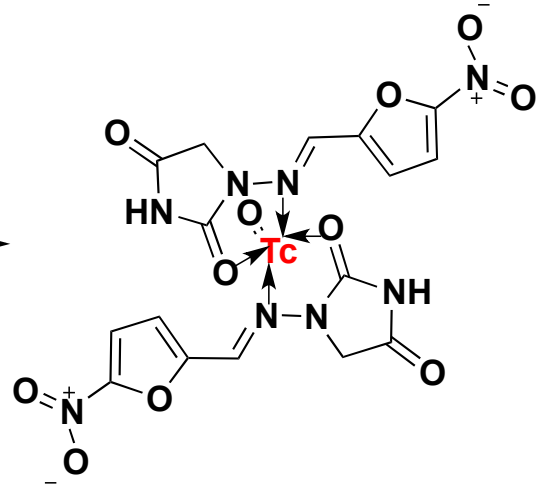

Scheme 12. Synthesis of ${ }^{99 \mathrm{~m}} \mathrm{Tc}-$ Nitrofurantoin

\subsubsection{Oxazolidinones}

Linezolid is an oxazolidinone-type antibiotic that inhibits the bacterial protein synthesis initiation and shows activity against gram-positive microorganisms [158]. Iodine-131$\left({ }^{131}\right.$ I)-linezolid was proven to be used for imaging S. aureus in a rat model. In the bacterial infected foci, the accumulation of this labeled antibiotic was five times more compared to the sterile inflammation sites in $30 \mathrm{~min}$. In order to radiolabel linezolid with ${ }^{131} \mathrm{I}$, to an iodogen coated vial, a linezolid solution was added followed by $\mathrm{Na}^{131} \mathrm{I}$ and incubation at room temperature. Finally, $\mathrm{Na}_{2} \mathrm{SO}_{3}$ was added to the mixture to complete the reaction (Scheme 13) [159]. 


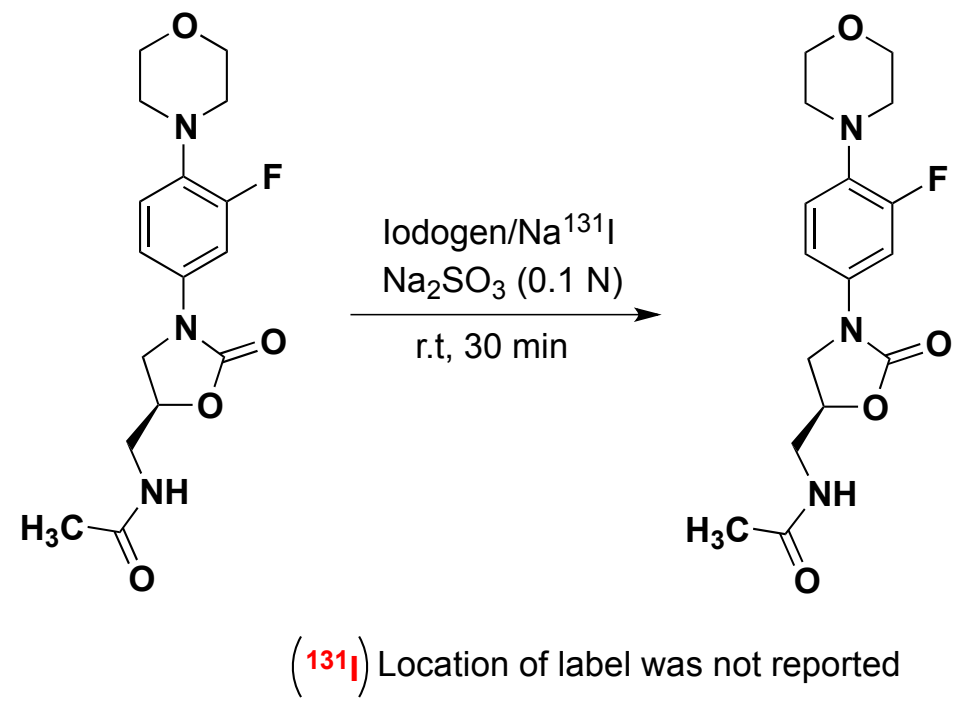

Scheme 13. Synthesis of ${ }^{131}$ I-Linezolid

\subsubsection{Fluoroquinolones}

Fluoro-quinolones prevent the DNA synthesis of bacteria by interacting with the DNA gyrase which eventually restricts uncoiling of DNA [5]. A large number of compounds in this group of antibiotics were radiolabeled with ${ }^{99 m} \mathrm{Tc},{ }^{18} \mathrm{~F}$ and ${ }^{68} \mathrm{Ga}$ for radiopharmaceutical studies. As recently reviewed, PET or SPECT imaging using radiolabeled quinolones distinguished between infection and inflammation in various infected animal models as well as in human subjects. Radiolabeling procedures with ${ }^{99 m}$ Tc were used to study the potential of fluoroquinolones as imaging probes and included ciprofloxacin, enrofloxacin, difloxacin, perfloxacin, lomefloxacin, ofloxacin, rufloxacin (Scheme 14), norfloxacin, danoflaoxacin, sparfloxacin, levofloxacin, moxifloxacin (Scheme 15), gemifloxacin (Scheme 16), garenoxacin (Scheme 17), clinafloxacin (Scheme 18), gatifloxacin and trovafloxacin [131, 143, 157, 160-172]. Radiolabeling for these antibiotics was carried out with $\mathrm{SnCl}_{2} \cdot 2 \mathrm{H}_{2} \mathrm{O}$ and ${ }^{99} \mathrm{TcO}_{4}{ }^{-}$with the exception for enrofloxacin where stanous tartrate was used. However, in case of levofloxacin and gemifloxacin (Scheme 16) sodium pertechnetate was used in place of 
${ }^{99} \mathrm{TcO}_{4}{ }^{-}$. The antibiotics ciprofloxacin, fleroxacin and trovafloxacin were also radiolabeled with ${ }^{18} \mathrm{~F}$. For the synthesis of ${ }^{18} \mathrm{~F}$-fleroxacin; 6,7,8-trifluoro-1,4-dihydro1-(2-hydroxyethyl)-4-oxo-3-quinolinecarboxylic acid ethyl ester was produced by alkylating 6,7,8- trifluoro-4-hydroxyquinoline-3-carboxylic acid ethyl ester with 2bromoethanol and a subsequent condensation with 1-methyl-piperazine to form the precusor of fleroxacin. The reaction was followed by the addition of methanesulfonyl chloride which resulted in the mesylate precursor of fleroxacin. The anionic form of ${ }^{18} \mathrm{~F}$, in the presence of Kryptofix, substituted the mesylate followed by basic hydrolysis resulting in the synthesis of ${ }^{18} \mathrm{~F}$-fleroxacin [173]. In the case of trodoxacin labeling; ${ }^{18} \mathrm{~F}$ was dried in the presence of $\mathrm{K}_{2} \mathrm{CO}_{3}$ and Kryptofix. To this mixture trodoxacin in DMSO was added and heated to yield the radiolabeled product [172].

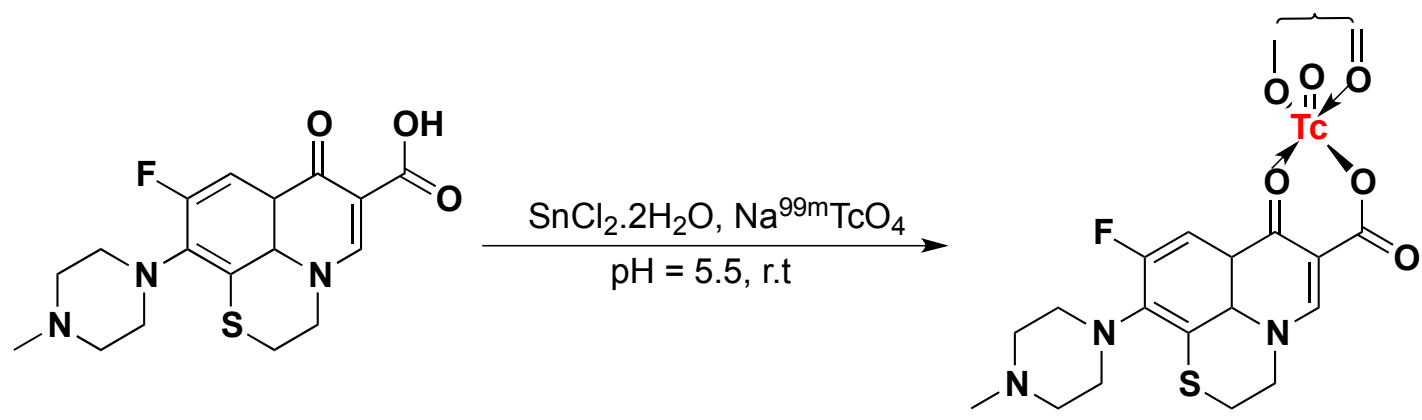

Scheme 14. Synthesis of ${ }^{99 m}$ Tc-Rufloxacin<smiles>COc1c(N2C[C@@H]3CCCN(C([NH3+])=S)[C@@H]3C2)c(F)cc2c(=O)c(C(=O)O)cn(C3CC3)c12</smiles>

Scheme 15. Synthesis of ${ }^{99 \mathrm{~m}} \mathrm{Tc}-$ Moxifloxacin 

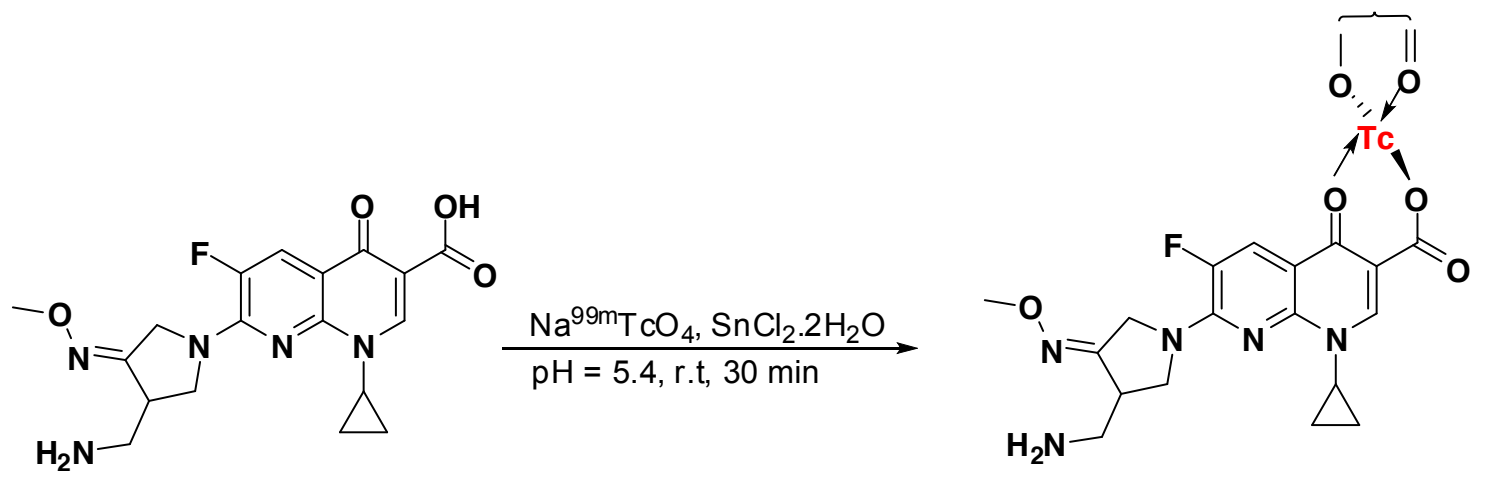

Scheme 16. Synthesis of ${ }^{99 \mathrm{~m}}$ Tc-Gemifloxacin

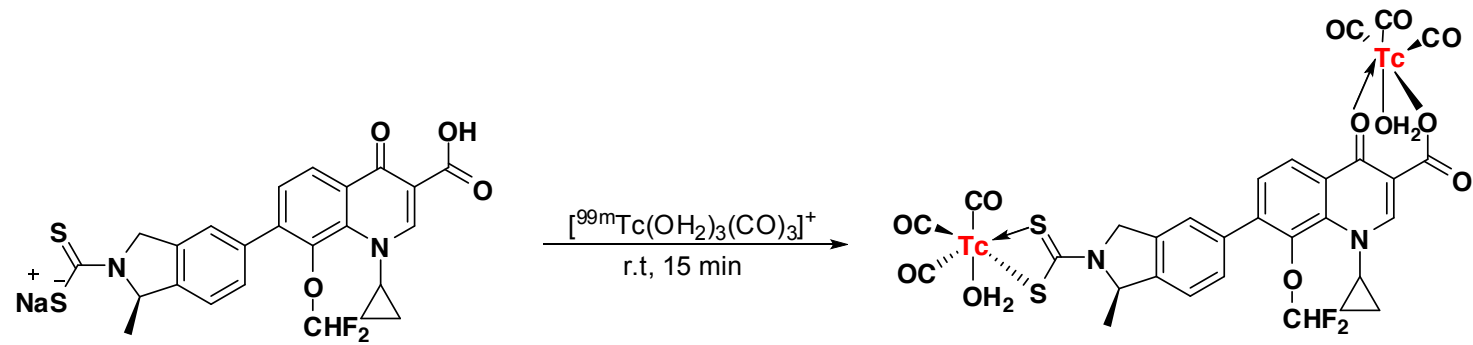

Scheme 17. Synthesis of ${ }^{99 \mathrm{~m}} \mathrm{Tc}(\mathrm{CO})_{3}$-Garenoxacin dithocarbamate

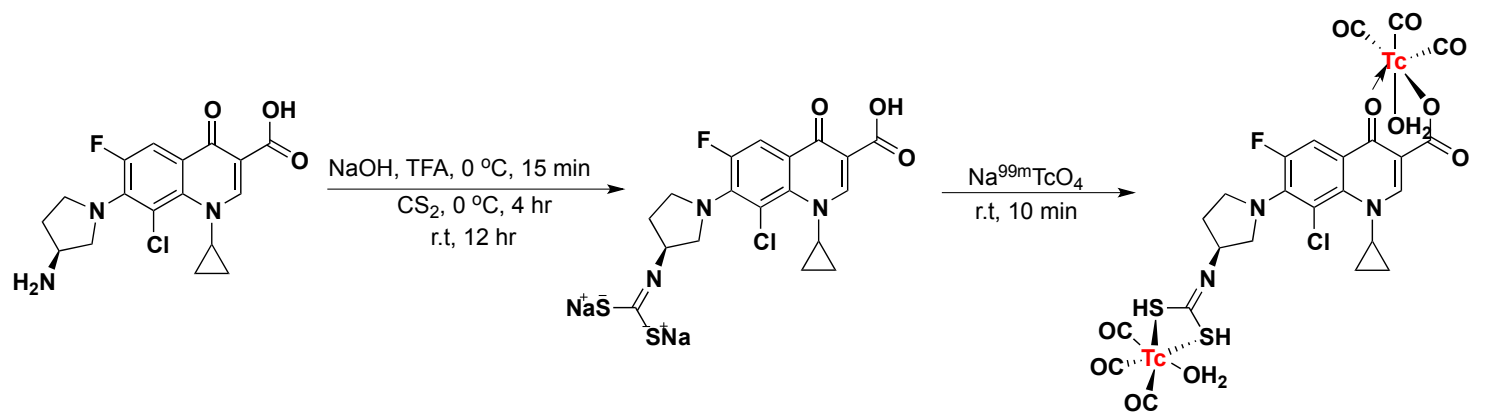

Scheme 18. Synthesis of ${ }^{99 \mathrm{~m}} \mathrm{Tc}(\mathrm{CO})_{3}$-Clinafloxacin

Ciprofloxacin was also successfully radiolabeled with ${ }^{68} \mathrm{Ga}$. Ciprofloxacin propyl amine was reacted with $p$-SCN-Bz-DOTA or $p$-SCN-Bz-NOTA to produce the DOTAand NOTA-conjugates of ciprofloxacin, respectively. Radiolabeling was conducted by incubating ${ }^{68} \mathrm{Ga}$ with DOTA- or NOTA-ciprofloxacin at $70{ }^{\circ} \mathrm{C}$ or room temperature, respectively (Scheme 19) [174]. 


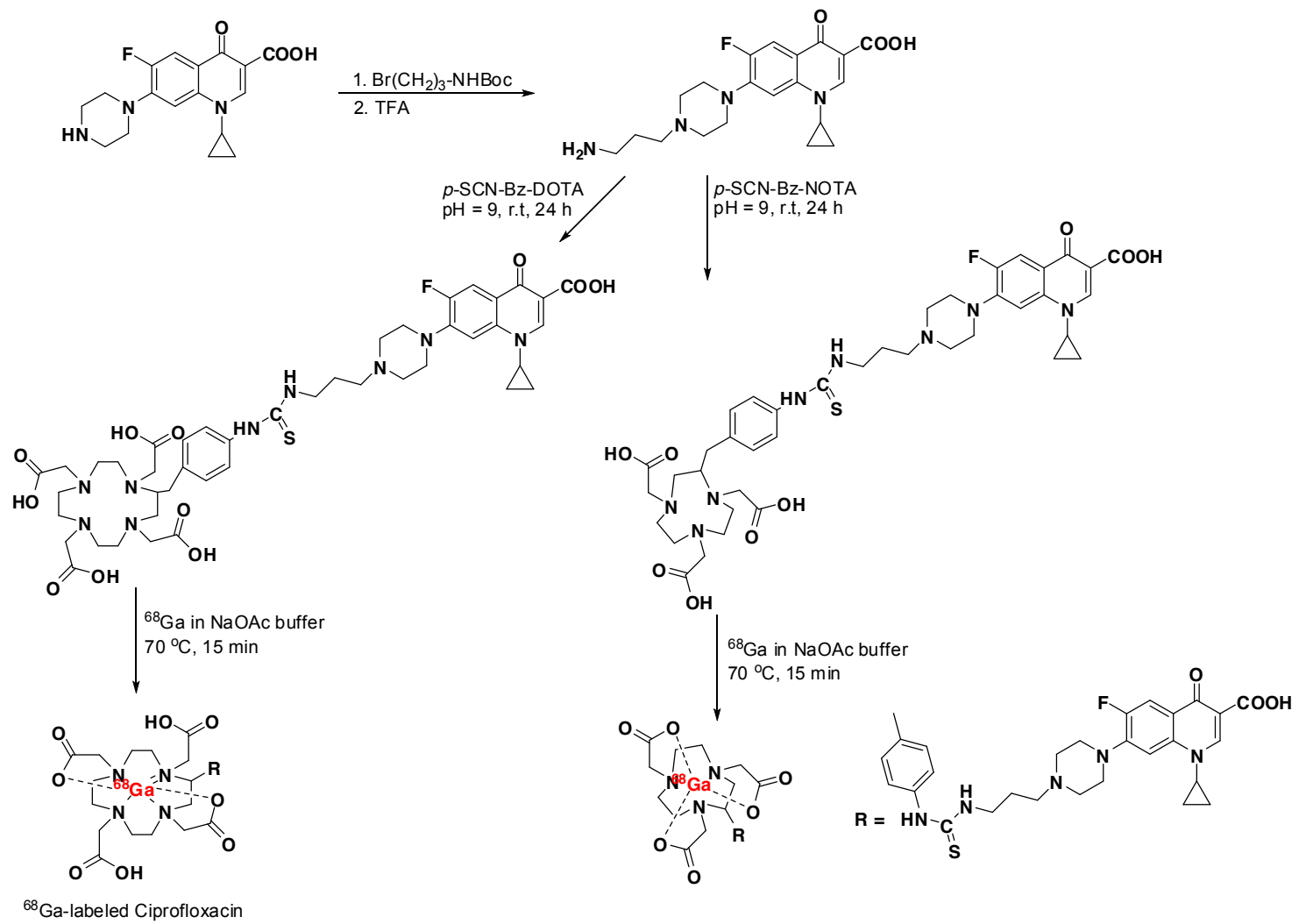

Scheme 19. Synthesis of ${ }^{68}$ Ga-DOTA-Ciprofloxacin and ${ }^{68}$ Ga-NOTA-Ciprofloxacin

\subsubsection{Anti-mycobacteria}

Rifampicin (Scheme 20) and ethambutol (Scheme 21) were radiolabeled with ${ }^{99 \mathrm{~m}} \mathrm{TcO}_{4}{ }^{-}$ in the presence of $\mathrm{SnCl}_{2} \cdot 2 \mathrm{H}_{2} \mathrm{O}$ or stannous tartrate, respectively $[175,176]$; however, ${ }^{99 \mathrm{~m}} \mathrm{Tc}$-isoniazid was synthesized by utilizing co-ligands tricine and ethylenediamine$N, N^{\prime}$-diacetic acid (EDDA) with stannous chloride (Scheme 22) [177]. In addition, carbon-11 $\left({ }^{11} \mathrm{C}\right)$-radiolabeling procedures are reported for rifampicin and pyrazinamide. The rifampicin piperazine moiety was radiolabelled with ${ }^{11} \mathrm{CH}_{3} \mathrm{I}$ in the presence of potassium carbonate as the base in a mixture of DMSO and $\mathrm{ACN}$ as solvents (Scheme 23) [178]. The synthesis of ${ }^{11} \mathrm{C}$-isoniazid and ${ }^{11} \mathrm{C}$-pyrazinamide were initiated by reacting iodopyridine and 2-iodopyrazine with ${ }^{11} \mathrm{C}-\mathrm{HCN}$ respectively in the presence of the catalyst tetrakis(triphenylphosphine)palladium (0). In case of isoniazid, cyanide 
was hydrolyzed by hydrazine and the subsequent imine was hydrolyzed by water (Scheme 24). However, in case of pyrazinamide, the cyano-group of the product ${ }^{11} \mathrm{C}$ cyanopyrazine was hydrolyzed by hydrogen peroxide under basic conditions to yield $\left[{ }^{11} \mathrm{C}\right]$-pyrazinamide (Scheme 25) [178].
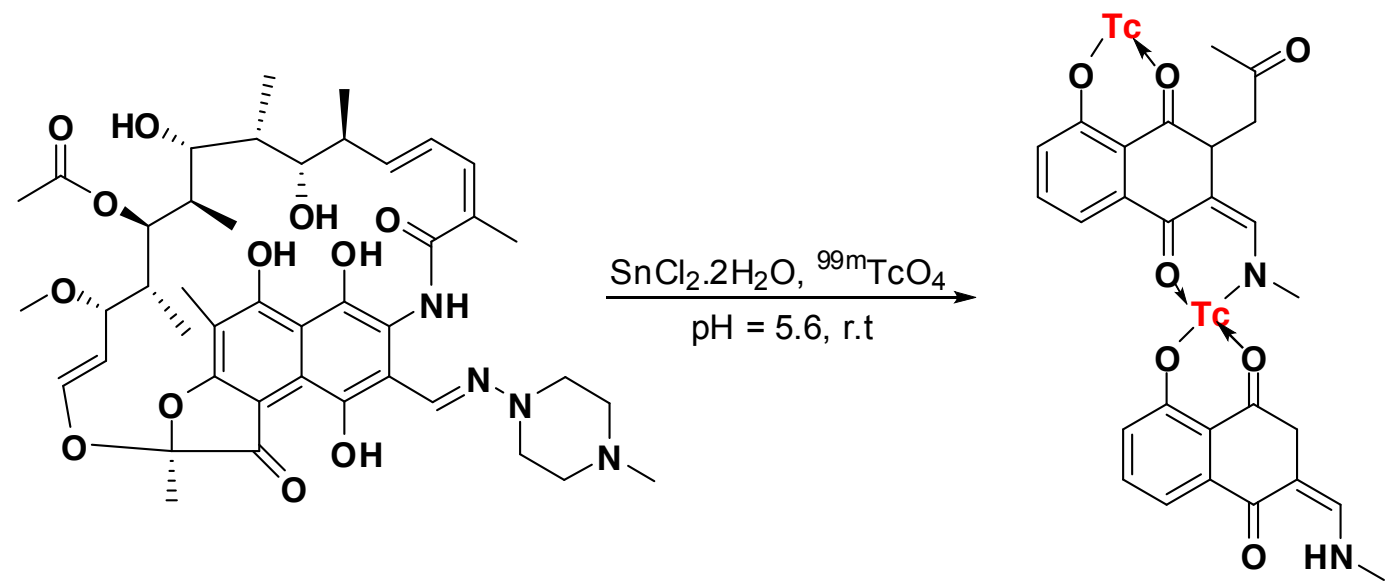

Scheme 20. Synthesis of ${ }^{99 m} \mathrm{Tc}$ - rifampicin<smiles>CCC(CO)NCCN[C@@H](CC)CO</smiles>

Scheme 21. Synthesis of ${ }^{99 m}$ Tc-ethambutol

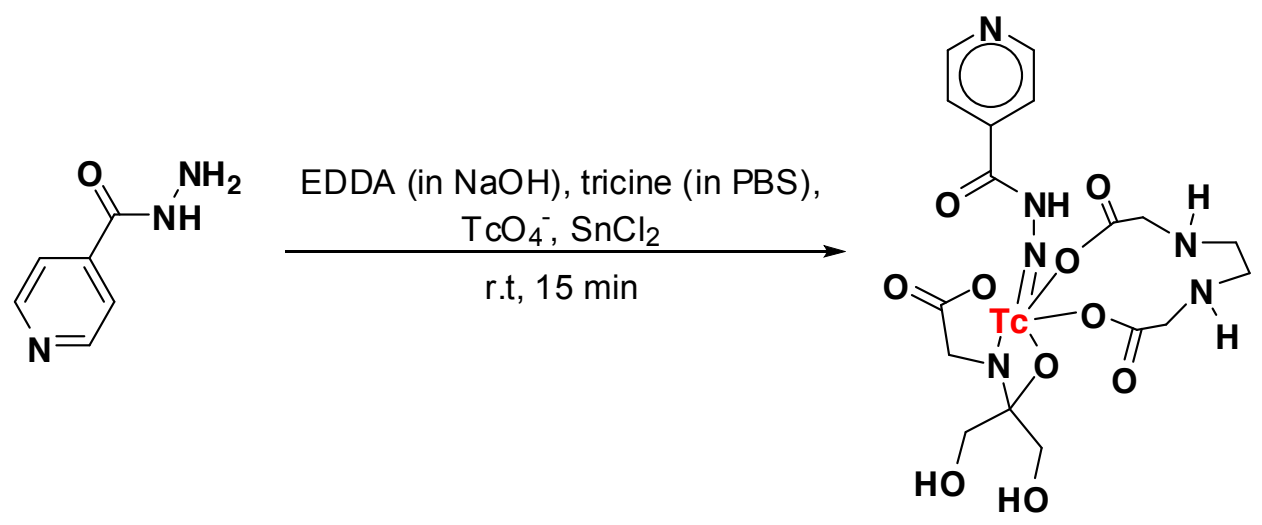

Scheme 22. Synthesis of ${ }^{99 \mathrm{~m}}$ Tc-isoniazid 

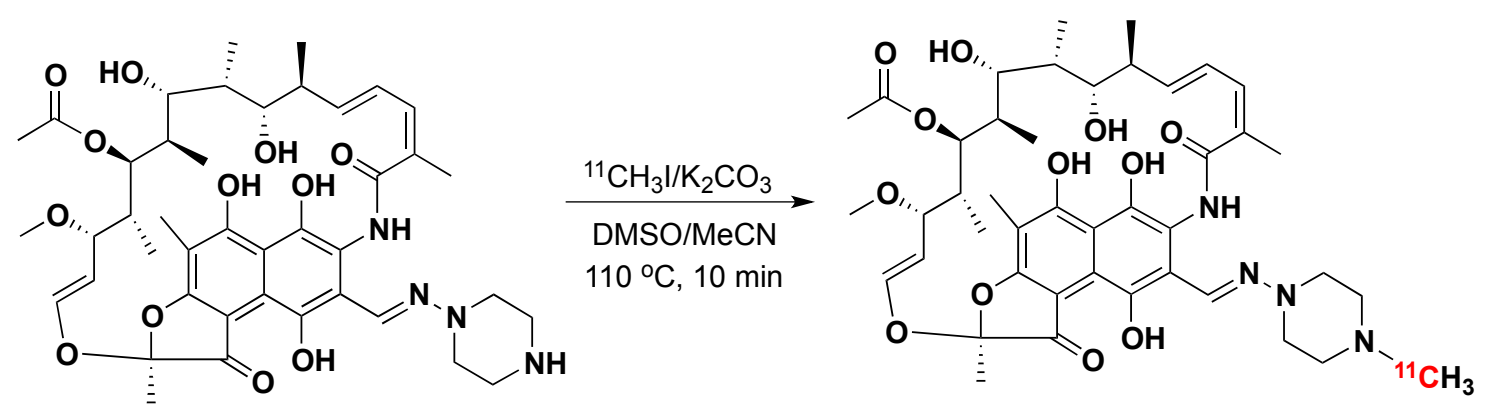

Scheme 23. Synthesis of ${ }^{11} \mathrm{C}$-rifampicin

$$
\underset{\substack{\mathrm{Pb}(\mathrm{PPh})_{4} / \mathrm{DMSO}, 135^{\circ} \mathrm{C}, 5 \mathrm{~min}}}{\stackrel{\mathrm{K}^{11} \mathrm{CN}, \mathrm{K}_{222}}{135^{\circ} \mathrm{C}, 5 \mathrm{~min}}}
$$

Scheme 24. Synthesis of ${ }^{11} \mathrm{C}$-Isoniazid

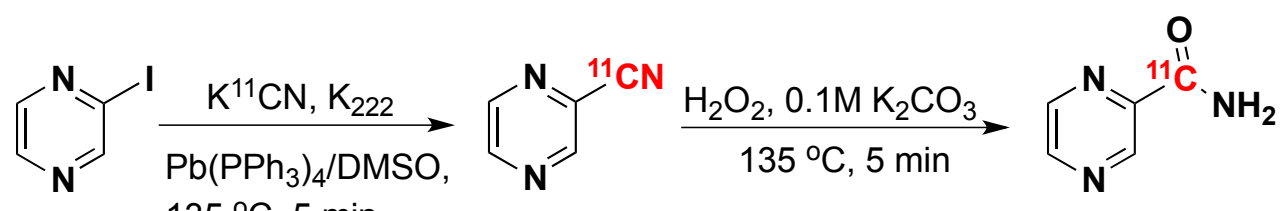
$135^{\circ} \mathrm{C}, 5 \mathrm{~min}$

Scheme 25. Synthesis of ${ }^{11} \mathrm{C}$-pyrazinamide

\subsubsection{Tetracyclines}

The mode of action with tetracycline antibiotics prevents the binding of the aminoacyltRNA to the ribosomal acceptor (A) site thereby inhibiting the protein synthesis [179]. One of the radiolabeled antibiotics from this group, ${ }^{99 \mathrm{~m}} \mathrm{Tc}$-doxycycline was explored in an E. coli-infected rat model. The study revealed a rapid accumulation of this radiotracer in the infected site and could easily be distinguished from the soft tissue. Doxycycline was radiolabeled with ${ }^{99 \mathrm{~m}} \mathrm{Tc}$ in the presence of stannous tartrate and ascorbic acid carried out at room temperature [180]. 
Table 3 Antibiotics-based probes for infection imaging

\begin{tabular}{|c|c|c|c|c|c|c|c|}
\hline $\begin{array}{l}\text { Antibiotics } \\
\text { class }\end{array}$ & $\begin{array}{c}\text { Antibiotic } \\
\text { name }\end{array}$ & Radioisotope & Targeted microorganism(s) ${ }^{\text {a) }}$ & $\begin{array}{c}\text { T/NT } \\
\text { ratio }\end{array}$ & $\begin{array}{l}\text { Labelling } \\
\text { efficiency }\end{array}$ & Detection & Reference \\
\hline \multirow[t]{4}{*}{ Aminoglycoside } & Kanamycin & ${ }^{99 \mathrm{~m}} \mathrm{Tc}$ & \multirow{4}{*}{$\begin{array}{l}\text { Some Gram-negative bacteria, } \\
\text { Staphylococci and M.tuberculosis }\end{array}$} & 2.5 & $95.0 \%$ & -- & {$[136]$} \\
\hline & Tobramycin & ${ }^{99 \mathrm{~m}} \mathrm{Tc}$ & & - & -- & Gamma camera & {$[138]$} \\
\hline & Gentamicin & ${ }^{99 \mathrm{~m}} \mathrm{Tc}$ & & - & $96.9 \%$ & Gamma counter & {$[137]$} \\
\hline & Streptomycin & ${ }^{99 \mathrm{~m}} \mathrm{Tc}$ & & 2.4 & $98.0 \%$ & SPECT & {$[135]$} \\
\hline $\begin{array}{l}\text { Amino- } \\
\text { penicillin }\end{array}$ & Amoxicillin & ${ }^{99 \mathrm{~m}} \mathrm{Tc}$ & $\begin{array}{l}\text { Susceptible Gram-positive and Gram- } \\
\text { negative bacteria }\end{array}$ & 4.2 & $>90 \%$ & Dual head gamma camera & {$[140]$} \\
\hline \multirow{4}{*}{$\begin{array}{l}\text { Anti- } \\
\text { mycobacteria }\end{array}$} & Isoniazid & ${ }^{99 \mathrm{~m}} \mathrm{Tc}$ and ${ }^{18} \mathrm{~F}$ & \multirow{4}{*}{$\begin{array}{l}\text { Mainly } M \text {. tuberculosis and a few Gram- } \\
\text { positive bacteria }\end{array}$} & 1.3 & -- & $\mathrm{PET} / \mathrm{CT}$ & {$[181]$} \\
\hline & Ethambutol & ${ }^{99 m} \mathrm{Tc}$ & & - & $>85.0 \%$ & SPECT & {$[175]$} \\
\hline & Rifampicin & ${ }^{99 \mathrm{~m}} \mathrm{Tc}$ and ${ }^{11} \mathrm{C}$ & & 7.3 & & Gamma camera, PET & {$[178]$} \\
\hline & Pyrazinamide & ${ }^{11} \mathrm{C}$ & & - & $99.0 \%$ & PET & [178] \\
\hline \multirow[t]{6}{*}{ Cephalosporins } & Cefuroxine & ${ }^{99 \mathrm{~m}} \mathrm{Tc}$ & $\begin{array}{l}\text { Susceptible Gram-positive and -negative } \\
\text { bacteria }\end{array}$ & 2.5 & $98.0 \%$ & $\mathrm{Cd}(\mathrm{Te})$ detector & {$[141]$} \\
\hline & Ceftizoxine & ${ }^{99 \mathrm{~m}} \mathrm{Tc}$ & \multirow{4}{*}{$\begin{array}{l}\text { Susceptible enteric Gram-positive and - } \\
\text { negative bacteria incl. } H \text {. influenza }\end{array}$} & 3.2 & $94.9 \%$ & Gamma camera & {$[144,182]$} \\
\hline & Ceftriaxone & ${ }^{99 \mathrm{~m}} \mathrm{Tc}$ & & 5.6 & $96.0 \%$ & Gamma camera & {$[142,183]$} \\
\hline & Cefotaxime & ${ }^{99 \mathrm{~m}} \mathrm{Tc}$ & & 3.0 & $92.0 \%$ & Planar scintigraphy & {$[145]$} \\
\hline & Cefoperazone & ${ }^{99 \mathrm{~m}} \mathrm{Tc}$ & & 4.5 & $97.9 \%$ & $\gamma$-scintillation counter & {$[146]$} \\
\hline & Cefepime & ${ }^{99 \mathrm{~m}} \mathrm{Tc}$ & $\begin{array}{l}\text { Extended spectrum of Gram-positive and - } \\
\text { negative bacteria }\end{array}$ & 8.4 & $98 \pm 1.4 \%$ & -- & {$[143]$} \\
\hline \multirow[t]{4}{*}{$\begin{array}{l}\text { (Fluoro)- } \\
\text { Quinolones }\end{array}$} & Ciprofloxacin & ${ }^{68} \mathrm{Ga},{ }^{18} \mathrm{~F}$ and ${ }^{99 \mathrm{~m}} \mathrm{Tc}$ & \multirow[t]{4}{*}{$\begin{array}{l}\text { Susceptible Gram-positive and -negative } \\
\text { bacteria and fungi }\end{array}$} & $1.8-5.5$ & $\begin{array}{r}85.0-90.0 \% / \\
81 \pm 4 \%\end{array}$ & PET, Scintigraphy & {$[131,160,174,184,185]$} \\
\hline & Difloxacin & ${ }^{99 \mathrm{~m}} \mathrm{Tc}$ & & 5.5 & $95.6 \%$ & $\mathrm{NaI}(\mathrm{Tl})$ detector & {$[162]$} \\
\hline & Perfloxacin & ${ }^{99 \mathrm{~m}} \mathrm{Tc}$ & & 4.9 & $98.1 \%$ & $\mathrm{NaI}(\mathrm{Tl})$ detector & [162] \\
\hline & Lomefloxacin & ${ }^{99 \mathrm{~m}} \mathrm{Tc}$ & & 6.5 & $93.6 \%$ & $\gamma$-scintillation counter & [163] \\
\hline
\end{tabular}




\begin{tabular}{|c|c|c|c|c|c|c|c|}
\hline & Ofloxacin & ${ }^{99 \mathrm{~m}} \mathrm{Tc}$ & & 4.3 & $96.6 \%$ & $\gamma$-scintillation counter & {$[163]$} \\
\hline & Rufloxacin & ${ }^{99 \mathrm{~m}} \mathrm{Tc}$ & & 6.0 & $\begin{array}{r}98.10 \pm \\
0.18 \%\end{array}$ & $\begin{array}{l}\text { Well counter interface with } \\
\text { scalar count rate meter ( } \\
\text { WCSCR) }\end{array}$ & {$[164]$} \\
\hline & Norfloxacin & ${ }^{99 \mathrm{~m}} \mathrm{Tc}$ & & 6.9 & $95.4 \%$ & Scintigraphy & {$[165,186]$} \\
\hline & Danoflaoxacin & ${ }^{99 \mathrm{~m}} \mathrm{Tc}$ & & 7.2 & $90 \pm 2 \%$ & $\begin{array}{l}\text { Well-type c-scintillation } \\
\text { detector }\end{array}$ & {$[166]$} \\
\hline & Sparfloxacin & ${ }^{99 \mathrm{~m}} \mathrm{Tc}$ & Many Gram-positive and Gram-negative & 5.9 & $>95 \%$ & Gamma camera & [167] \\
\hline & Levofloxacin & ${ }^{99 \mathrm{~m}} \mathrm{Tc}$ & bacteria & 7.2 & $99.74 \%$ & Scintigraphy & {$[168]$} \\
\hline & Fleroxacin & ${ }^{18} \mathrm{~F}$ & & 1.3 & $5-8 \%$ & PET & {$[173]$} \\
\hline & Moxifloxacin & ${ }^{99 \mathrm{~m}} \mathrm{Tc}$ & Susceptible Gram-positive and Gram- & 6.8 & -- & WCSCR & {$[169]$} \\
\hline & Gemifloxacin & ${ }^{99 \mathrm{~m}} \mathrm{Tc}$ & $\begin{array}{l}\text { negative bacteria } \\
\text { incl. Methicillin-resistant } S \text {. aureus }\end{array}$ & 4.9 & -- & $\begin{array}{l}\text { Single well counter interface } \\
\text { with scalar count rate meter }\end{array}$ & {$[187]$} \\
\hline & Clinafloxacin & ${ }^{99 \mathrm{~m}} \mathrm{Tc}$ & $\begin{array}{l}\text { (MRSA) and } \\
\text { Penicillin-resistant Strentococci stains }\end{array}$ & 5.0 & -- & $\begin{array}{l}\text { Single well counter fitted with } \\
\text { a scalar count rate meter }\end{array}$ & {$[170]$} \\
\hline & Garenoxacin & ${ }^{99 \mathrm{~m}} \mathrm{Tc}$ & (PRSC) & 5.4 & $\begin{array}{r}98.25 \pm \\
0.22 \%\end{array}$ & WCSCR & {$[171]$} \\
\hline & Gatifloxacin & ${ }^{99 \mathrm{~m}} \mathrm{Tc}$ & & 4.5 & $90 \pm 1.8 \%$ & -- & [143] \\
\hline & Trovafloxacin & ${ }^{18} \mathrm{~F}$ and ${ }^{99 \mathrm{~m}} \mathrm{Tc}$ & & 6.0 & $15-30 \%$ & PET & {$[172]$} \\
\hline Glycopeptide & Vancomycin & ${ }^{99 \mathrm{~m}} \mathrm{Tc}$ & Susceptible Gram-positive bacteria incl. & 5.0 & $>95 \%$ & Gamma counter & {$[8]$} \\
\hline & Teicoplanin & ${ }^{99 \mathrm{~m}} \mathrm{Tc}$ & $\begin{array}{l}\text { Methicillin-resistant S. aureus (MRSA) } \\
\text { and E.faecalis }\end{array}$ & 4.3 & $87.7 \pm 1.3 \%$ & Scintigraphy & {$[148,188]$} \\
\hline Lincosamide & Clindamycin & ${ }^{99 \mathrm{~m}} \mathrm{Tc}$ & Susceptible Gram-positive and Gram- & 3.1 & $>95 \%$ & Scintigraphy 85 & {$[152]$} \\
\hline & Lincomycin & ${ }^{99 \mathrm{~m}} \mathrm{Tc}$ & negative bacteria & 3.0 & $>98 \%$ & \begin{tabular}{|l} 
Scintigraphy 86 \\
\end{tabular} & [151] \\
\hline Macrolides & Azithromycin & ${ }^{99 \mathrm{~m}} \mathrm{Tc}$ & Gram-positive-, some Gram-negative- and & 6.2 & $97.5 \pm 0.9 \%$ & -- & {$[153]$} \\
\hline & Erytmocytin & ${ }^{99 \mathrm{~m}} \mathrm{Tc}$ & atypical bacteria. & 2.4 & $>98 \%$ & Scintigraphy & [155] \\
\hline & $\begin{array}{l}\text { Clarithromyci } \\
\mathrm{n}\end{array}$ & ${ }^{99 \mathrm{~m}} \mathrm{Tc}$ & & 7.3 & $98 \pm 0.2 \%$ & $\begin{array}{l}\text { well-type } \mathrm{NaI} \text { scintillation } \gamma \text { - } \\
\text { ray counter }\end{array}$ & {$[154]$} \\
\hline Nitrofurans & Nitrofuratoin & ${ }^{99 \mathrm{~m}} \mathrm{Tc}$ & Susceptible Gram-positive and Gram- & 7.3 & $97.50 \pm$ & Scintigraphy & {$[157]$} \\
\hline
\end{tabular}




\begin{tabular}{|c|c|c|c|c|c|c|c|}
\hline $\begin{array}{l}\text { (DNA } \\
\text { inhibitors) }\end{array}$ & & & negative bacteria & & $0.16 \%$ & & \\
\hline Oxaolidinones & Linezolid & ${ }^{131} \mathrm{I}$ & $\begin{array}{l}\text { Susceptible Gram-positive and Gram- } \\
\text { negative bacteria }\end{array}$ & 77.48 & $85 \pm 1 \%$ & $\mathrm{Cd}(\mathrm{Te})$ detector & [159] \\
\hline Tetracyclines & Doxycycline & ${ }^{99 \mathrm{~m}} \mathrm{Tc}$ & $\begin{array}{l}\text { All medically relevant aerobic and } \\
\text { anaerobic bacteria } \\
\text { (Gram-positive, Gram-negative and } \\
\text { atypical) }\end{array}$ & $\begin{array}{r}2.24 \pm \\
0.84\end{array}$ & -- & Scintigraphy & [180] \\
\hline
\end{tabular}

a) Bacteria targeted based on the antibiotics class preferences (not the radiolabeled equivalent), some candidates may divert slightly in their sensitivity or specificity towards single types of bacteria.

b) T/NT: target to non-target 


\subsubsection{Vitamins}

\subsubsection{Biotin (Vitamin H)}

Biotin is an essential growth factor for some bacteria and is required for the metabolism of amino acids and fats. It is also involved in the production of fatty acids [189]. ${ }^{111} \mathrm{In}-$ labeled biotin demonstrated avid uptake in cultures of S. aureus [190]. Radiolabeled biotin also showed selectivity and specificity towards spinal infections in patients [191]. Biotin radiolabeling has been reported using the bifunctional chelator molecule diethylenetriaminepentaacetic acid (DTPA). Commercially available DTPA-Biotin was incubated with ${ }^{111}$ In-chloride at room temperature for optimal radiolabeling [190, 191]. DOTA-functionalized biotin was also successfully labeled with ${ }^{68} \mathrm{Ga}$ (buffered with HEPES). ${ }^{68}$ Ga-complexations were conducted at both at room and elevated (90 $\left.{ }^{\circ} \mathrm{C}\right)$ temperatures (Scheme 26) [192].
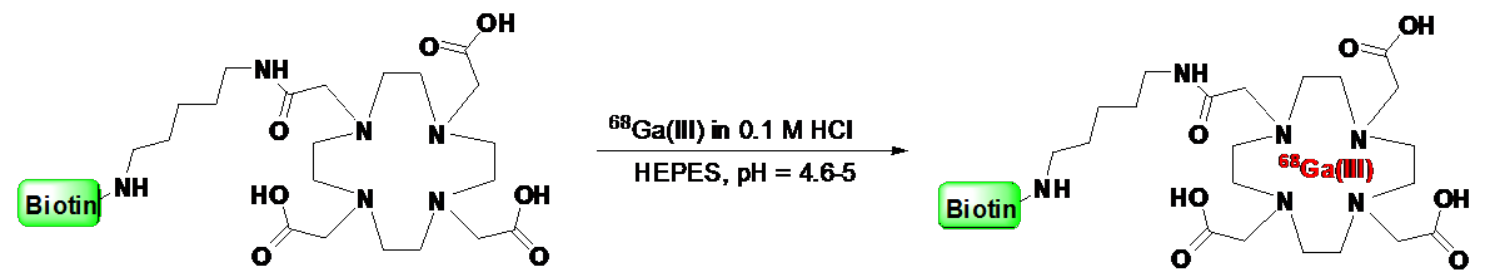

Scheme 26. Radiosynthesis of ${ }^{68}$ Ga-DOTA-Biotin

\subsubsection{Cyano-cobalamin (CBL)}

Cyano-cobalamins are transported by cobalamin transport proteins. These proteins have antagonistic effects against bacterial growth and colonization; and are found in salivary glands and secondary granules of granulocytes [193]. Baldoni et. al. reported on the rapid in vitro specificity of the CBL derivative ${ }^{99 \mathrm{~m}}$ Tc-PAMA(4)-CBL towards $S$. aureus and E.coli [194]. Waibel et.al. demonstrated the synthesis and radiolabeling of ${ }^{99 m}$ Tc-PAMA-CBL [195]; Cbl-b-acid (obtained by the controlled acid hydrolysis of cyano-cobalamin in $0.1 \mathrm{~mol} / \mathrm{L} \mathrm{HCl}$ ) was coupled with Boc-deprotected PAMA using 
coupling reagents, either 1-(3-dimethylaminopropyl)-3-ethylcarbodimide hydrochloride or 2-(1H-benzotriazole-1-y1)-1,1,3,3-tetramethyluronium tetrafluoro-borate, to synthesize Cbl-b-(ethyl-hexyl)-PAMA-OEt. To achieve optimal radiolabeling, $\left[{ }^{99 \mathrm{~m}} \mathrm{Tc}(\mathrm{CO})_{3}\left(\mathrm{OH}_{2}\right)_{3}\right]^{+}$was prepared using the isolink kit by heating $[\mathrm{Na}]\left[{ }^{99 \mathrm{~m}} \mathrm{TcO}_{4}\right]$. Cblb-(ethyl-hexyl)-PAMA-OEt was then incubated with $\left[{ }^{99 \mathrm{~m}} \mathrm{Tc}(\mathrm{CO})_{3}\left(\mathrm{OH}_{2}\right)_{3}\right]^{+}$in $2-(N-$ morpholino)ethanesulfonic acid (MES) buffer at $75{ }^{\circ} \mathrm{C}$ under a nitrogen environment $[194,195]$.

\subsubsection{Aptamers (Oligomers)}

Aptamers may be an emerging class of compounds which can be potential radiopharmaceutics because of their high target affinity and specificity; moreover, these probes can be custom designed towards a specific target [196] such as cell surface pathogen-specific proteins or bacteria-specific receptors [197]. S. aureus specific aptamers SA20, SA23 and SA34 were successfully labeled with ${ }^{99 \mathrm{~m}}$ Tc, which showed high uptake in the infected site (S. aureus) compared to the muscle infected with $C$. albicans and zymosan developed inflammation [198]. The radiolabeling was carried out by adding tricine, EDDA into $0.9 \%$ saline and the aptamers followed by the addition of $\mathrm{SnCl}_{2} \cdot 2 \mathrm{H}_{2} \mathrm{O}$. After adjusting the $\mathrm{pH}$ to 7 , the reaction vessel was sealed and a vacuum was created. ${ }^{99} \mathrm{TcO}_{4}{ }^{-}$was added and the mixture refluxed to facilitate the radiolabeling (Scheme 27) [198].

\section{Tricine and EDDA in $0.9 \%$ saline}

\section{Aptamer $\underset{3 . \mathrm{Na}^{99 \mathrm{~m}} \mathrm{TcO}_{4}^{-} \text {reflux }}{2 . \mathrm{SnCl}_{2} 2 \mathrm{H}_{2} \mathrm{O}}=\mathrm{Tc}^{99 \mathrm{~mm}} \sim$ Aptamer}

Scheme 27. Principle of direct ${ }^{99 \mathrm{~m}}$ Tc-radiolabeling of aptamers

Chen et. al. demonstrated the specificity of the radiolabeled oligomers towards the RNA of S. aureus, K. pneumoniae and E. coli [199]. The oligomers that were 
investigated included phosphorodiamidate morpholino (MORF), peptide nucleic acids (PNA), and phosphorothioate DNA (PS-DNA) that were conjugated with NHS-MAG 3 [200]. The $\mathrm{MAG}_{3}$-conjugated oligomers were mixed with a solution of ammonium acetate, tartrate and freshly prepared $\mathrm{SnCl}_{2} \cdot 2 \mathrm{H}_{2} \mathrm{O}$ (in $\mathrm{HCl} /$ ascorbate) and vortexed. Finally, ${ }^{99 \mathrm{~m}} \mathrm{TcO}_{4}{ }^{-}$was added and the mixture was heated at $95{ }^{\circ} \mathrm{C}$ (Scheme 28) [199]. In another example, the same group demonstrated that the 12-mer phosphorodiamidate morpholino (MORF) oligomer, that was complementary to bacterial ribosomal RNA, was specific in its identification of $K$. pneumoniae in infected mouse muscles [201]. Radiolabeling was carried out in the similar manner as described above.
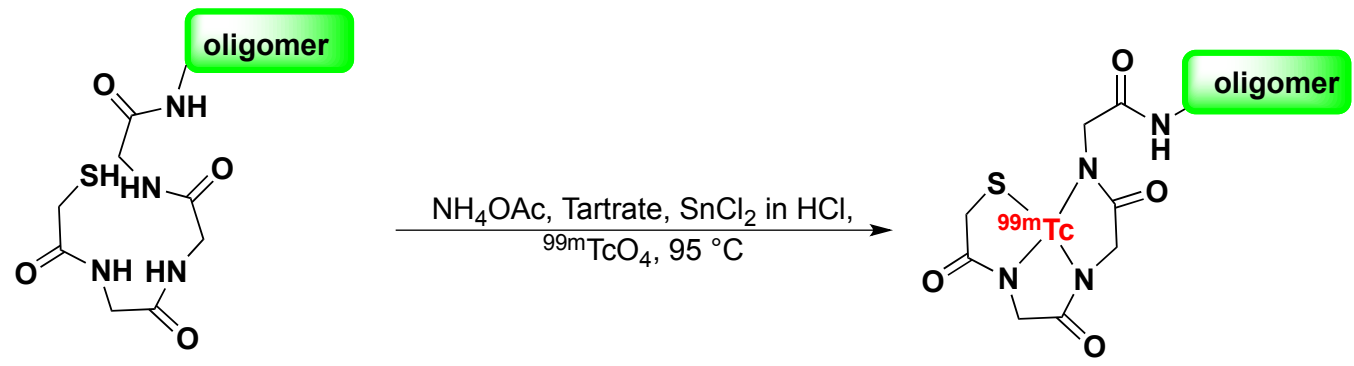

Oligomers $=$ MORF or PNA or DNA

Scheme 28. Synthesis of ${ }^{99 m}$ Tc-NHS-MAG $3-(M O R F / P N A / P S-D N A)$

\subsubsection{Puromycin}

Puromycin is a protein synthesis inhibitor that affects the derivatization of immature polypeptide chains as polypeptidyl-puromycin [202]. Eigner et. al. emphasised the potential of ${ }^{68} \mathrm{Ga}$-DOTA-Puromycin for imaging bacterial infections based on the fact that it can detect the protein synthesis of the microbial colonies [203]. The study revealed that there is no accumulation of the radiotracer in sites of sterile inflammation; however, high contrast $\mu \mathrm{PET} / \mathrm{CT}$ images were obtained in the subcutaneous colonies of S. aureus infected foci [203]. The investigators used commercially available DOTAPur for radiolabelling with ${ }^{68} \mathrm{Ga}$. Briefly, DOTA-Puromycin was added to a solution of 
freshly eluted ${ }^{68} \mathrm{Ga}$ (in $\mathrm{HCl}$ ) after $\mathrm{pH}$ adjustment and the reaction mixture was incubated at $95^{\circ} \mathrm{C}$ until completion followed by purification through a Strata-X column [203].

\subsubsection{Radiolabeled purines and pyrimidines}

Herpes simplex virus 1 (HSV1) thymidine kinase (TK) is an important enzyme for the transfer of a phosphate group to the $5^{\prime}$ hydroxyl group of pyrimidines from ATP. HSV1-TK reporter gene system can be of importance as its substrate can be radiolabeled for tracing. These radiotracers are subsequently phosphorylated and cellularly trapped upon introduction of the charge of the phosphate group [204]. This mechanism was successfully implemented in transformed tumor cells imaging and based on this fact it was approached for imaging TKs of bacteria in mammals [205]. Bettegowda et. al. demonstrated the selectivity of iodine-125 ( $\left.{ }^{125} \mathrm{I}\right)$-radiolabeled 1-(2'deoxy-2'-fluoro-5-iodo-1- $\beta$-D-arabinofuranosyl) -5-iodouracil (FIAU) towards TK of a wild-type E. coli strain [205]. Subsequent studies on ${ }^{125}$ I-FIAU revealed its application for imaging musculoskeletal infections in patients [206]. For radiolabeling, 1-(2'deoxy-2'-fluoro- $\beta$-D-arabinofuranoside)-uracil (FAU) was dissolved in $\mathrm{HNO}_{3}$ and to this solution ${ }^{125} \mathrm{I}-\mathrm{NaI}$ was added. The reaction was heated at $130{ }^{\circ} \mathrm{C}$ and finally quenched with a mixture of $\mathrm{ACN} / \mathrm{H}_{2} \mathrm{O} /$ triethylamine (Scheme 29).

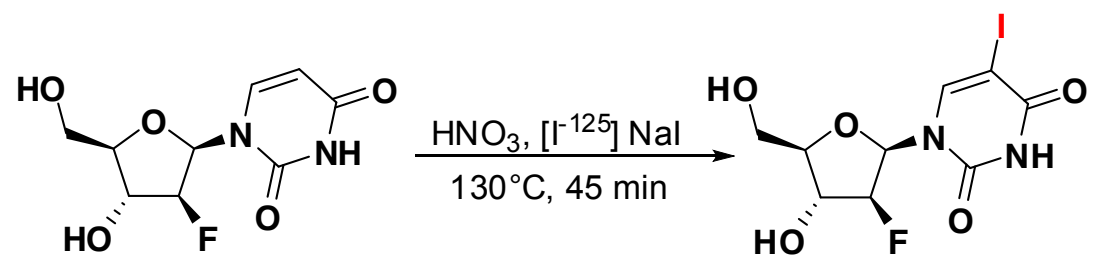

Scheme 29. Synthesis of ${ }^{125}$ I-FIAU 


\subsubsection{Glycopyranose derivatives}

Bacteria can utilize unique sugars such as maltose, sorbitol and trehalose as energy sources. However, mammalian cells are deficient in the transporters for these molecules which may bear great potential as probes for bacterial imaging [207]. The maltose derivatives $6-{ }^{18} \mathrm{~F}$-fluoromaltose and ${ }^{18} \mathrm{~F}$-maltohexanose $\left({ }^{18} \mathrm{~F}-\mathrm{MH}\right)$ have been synthesized and reported to be bacterial specific [208-210]. Cellular uptake of $6-{ }^{18} \mathrm{~F}-$ fluoromaltose by both gram positive and gram negative bacterial cells were reported in earlier literature; however, insignificant amounts were detected in tumor cells [209]. Likewise, ${ }^{18} \mathrm{~F}-\mathrm{MH}$ was also found to be selective and specific towards E. coli showing minimal affinity towards mammalian cells [210]. For the synthesis of $6-{ }^{18} \mathrm{~F}$ fluoromaltose; ${ }^{18}$ F-fluoride was eluted with a solution of $\mathrm{K}_{2} \mathrm{CO}_{3}$ and Kryptofix in water and acetonitrile. An anhydrous residue was obtained after evaporation of the solvent, which was then added to a 1,2,3-tri-O-acetyl-4-O-(2',3',-di-O-acetyl-4',6'-benzylidenea-D-glucopyranosyl)-6-deoxy-6-O-nosyl-D-glucopranosidic solution in ACN followed by heating at $80{ }^{\circ} \mathrm{C}$. This intermediate compound was purified using a C-18 Sep-Pak cartridge. The purified product was then first hydrolyzed by $\mathrm{HCl}$ at $110^{\circ} \mathrm{C}$ followed by addition of $\mathrm{NaOH}$ at room temperature to yield the $6-{ }^{18} \mathrm{~F}$-fluoromaltose (Scheme 30) [208].

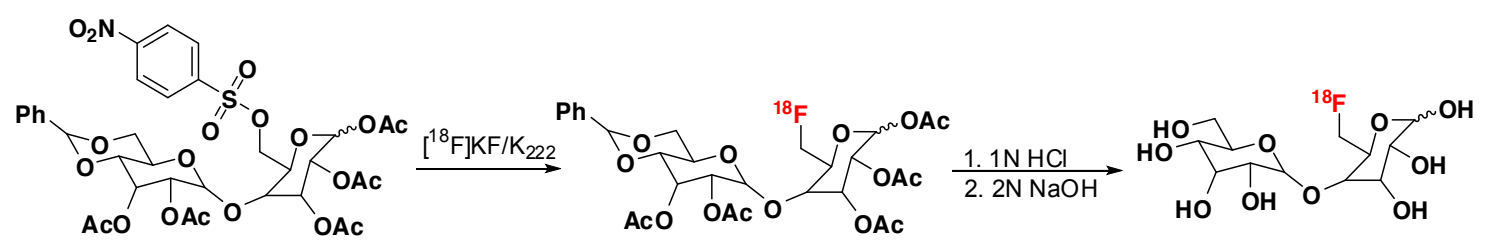

Scheme 30. Synthesis of $6-{ }^{18}$ F-fluoromaltose

Radiochemical synthesis of ${ }^{18} \mathrm{~F}-\mathrm{MH}$ was obtained by cryptate-mediated nucleophilic substitution of maltohexose-brosylate precursor with $\mathrm{K}^{18} \mathrm{~F}$ (in $\mathrm{ACN}$, at $110{ }^{\circ} \mathrm{C}$ ). The 
compound synthesized was then hydrolyzed with $\mathrm{NaOH}$ (in water, at $110^{\circ} \mathrm{C}$ ) followed by acid neutralization at room temperature (Scheme 31) [210].
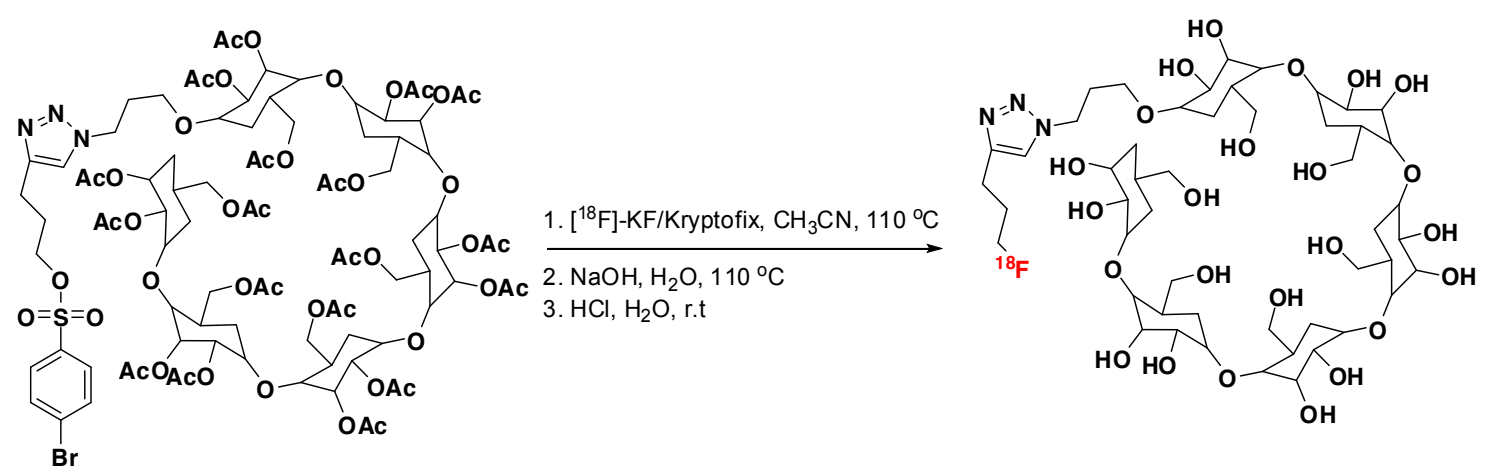

Scheme 31. Synthesis of ${ }^{18} \mathrm{~F}$-maltohexanose

Sorbitol is considered as a probe towards the identification of enterobacteriaceae because this class can selectively metabolize glycopyranose using the glycerol diffusion facilitator $(\mathrm{glpF})$. The radiolabeled sorbitol derivative ${ }^{18} \mathrm{~F}$-fluorodesoxysorbitol $\left({ }^{18} \mathrm{~F}\right.$ FDS) is reported to be target specific and also capable of identifying drug resistance [211-213]. ${ }^{18}$ F-FDS can be synthesized by reduction of commercially available ${ }^{18} \mathrm{~F}$ FDG by $\mathrm{NaBH}_{4}$ in water at $35{ }^{\circ} \mathrm{C}$ (Scheme 32) [211].

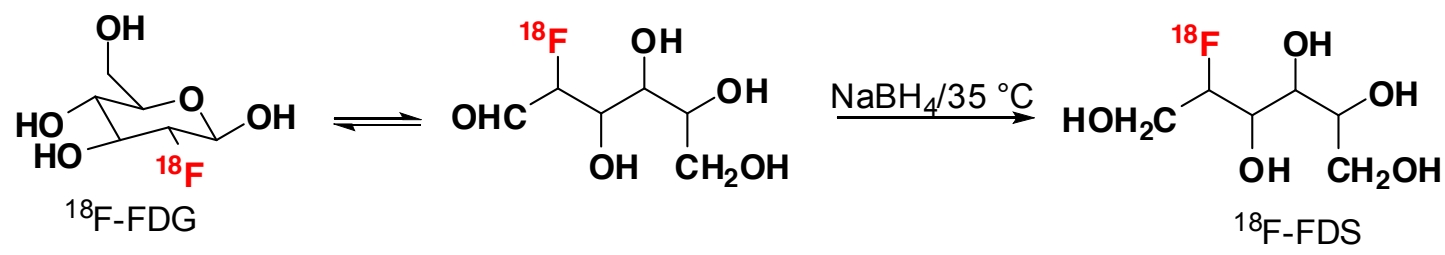

Scheme 32. Synthesis of ${ }^{18} \mathrm{~F}$-fluorodesoxysorbitol

The non-mammalian disaccharide trehalose is utilized by bacteria for stress protection, carbohydrate storage and even an energy source. It is also a constituent of the cell wall of some mycobacteria [214]. A trehalose derivative, 2-fluorotrehalose (2-FDT)PET/CT, was successfully applied for the detection of tubercular lesions in a rabbit infection model bearing Mycobacterium tuberculosis HN878 [215]. The 2- 
fluorotrehalose (2-FDT) synthesis is a biomimetic process, inspired by the bacterial synthesis of trehalose from glucose. Chemo-enzymatic synthesis of 2-FDT occurs as a one-pot cascade reaction in which hexokinase transfers a phosphate from adenosine triphosphate (ATP) to ${ }^{18} \mathrm{~F}-\mathrm{FDG}$ (normally glucose in bacterial trehalose synthesis). OtsA then transfers the glucose from the donor UDP-glucose to the acceptor phosphorylated ${ }^{18}$ F-FDG. Dephosphorylation gives the desired product that is affected by OtsB. The entire one-pot process is complete in $45 \mathrm{~min}$.

Amino sugars are one of the essential components of the bacterial cell wall. In both gram negative and gram positive bacteria, they form the peptidoglycan backbone. Bacterial cell walls are composed of alternate sequences of $\mathrm{N}$-acetylglucosamine and $\mathrm{N}$-acetylmuramic acid, joined by oligopeptides. The use of $\mathrm{N}$-acetylglucosamine as a radiotracer by incorporating a radioisotope bears potential hope for bacterial imaging. Martínez et. al. described the synthesis and application of 2-deoxy-2-( $\left.{ }^{18} \mathrm{~F}\right)$ fluoroacetamido-D-glucopyranose $\left({ }^{18} \mathrm{~F}-\mathrm{FAG}\right)$. They were capable of successfully identifying E. coli in infected rat models. The synthesis of ${ }^{18} \mathrm{~F}-\mathrm{FAG}$ was carried out by using 1,3,4,6-tetra-O-acetyl-2-deoxy-2-bromoacetamido-D-glucopyranose as a precursor with microwave heating. ${ }^{18} \mathrm{~F}$-fluorine eluted in a solution of $\mathrm{K}_{2} \mathrm{CO}_{3} /$ Kryptofix and was evaporated under microwave conditions $\left(110^{\circ} \mathrm{C}\right)$ in the presence of argon gas. Subsequently, the bromide precursor (in anhydrous ACN) was added to the dried $\left[\mathrm{K} / \mathrm{K}_{222}\right]^{+18} \mathrm{~F}^{-}$complex followed by hydrolysis with sodium hydroxide and finally neutralized by the addition of $\mathrm{HCl}$ (Scheme 33) [216].
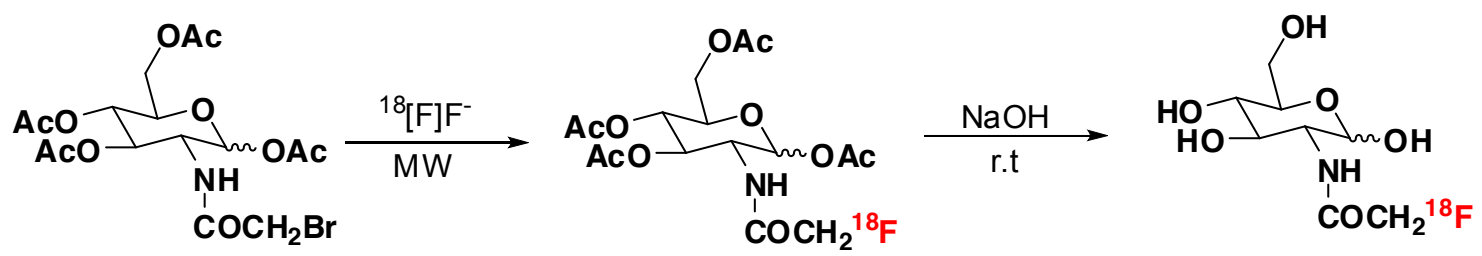
Scheme 33. Synthesis of ${ }^{18}$ F-FAG

\subsubsection{Siderophores}

All microorganisms, including bacteria and fungi, require iron as a trace element for their growth [217]. However the presence of $\mathrm{O}_{2}$ in the environment causes oxidation of ferrous $\left(2^{+}\right)$to ferric $\left(3^{+}\right)$iron which is insoluble. Bacteria produce siderophores; which are small peptide-like metabolites with the ability to chelate iron thereby making it available to the organism [218]. Moreover, a few siderophores also mediate the uptake of gallium $[219,220]$. Recent investigations described the ${ }^{68} \mathrm{Ga}$ radiolabeling potential of siderophores namely triacetylfusarinine $\mathrm{C}$ (TAFC) and ferrioxamine $\mathrm{E}$ (FOXE). Radiolabeled ${ }^{68} \mathrm{Ga}$-TAFC and ${ }^{68} \mathrm{Ga}$-FOXE showed rapid accumulation as well as specificity towards A. fumigatus in infected lung tissues. However, it also showed moderate accumulation in sterile inflamed tissue and no affinity towards $S$. aureus infected muscle $[66,221,222]$. For radiolabeling TAFC (Scheme 34) and FOXE (Scheme 35), they are incubated with ${ }^{68} \mathrm{Ga}$ in acetate buffer at room temperature and at $80{ }^{\circ} \mathrm{C}$ respectively [221].

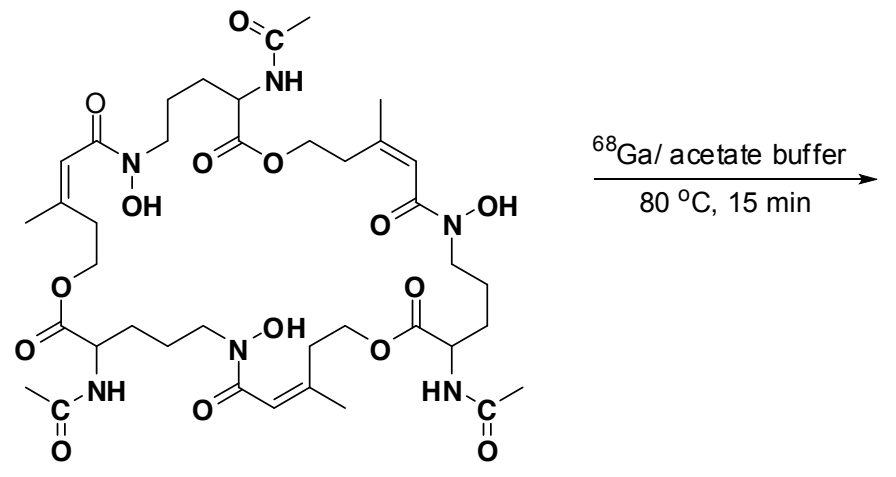

Scheme 34. Synthesis of ${ }^{68} \mathrm{Ga}-\mathrm{TAFC}$

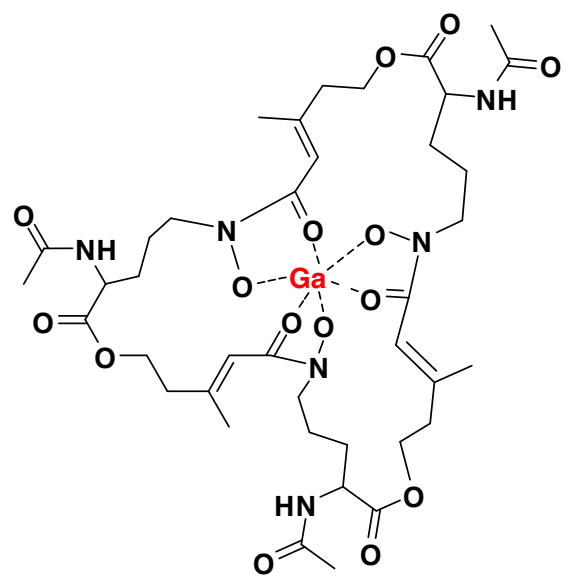



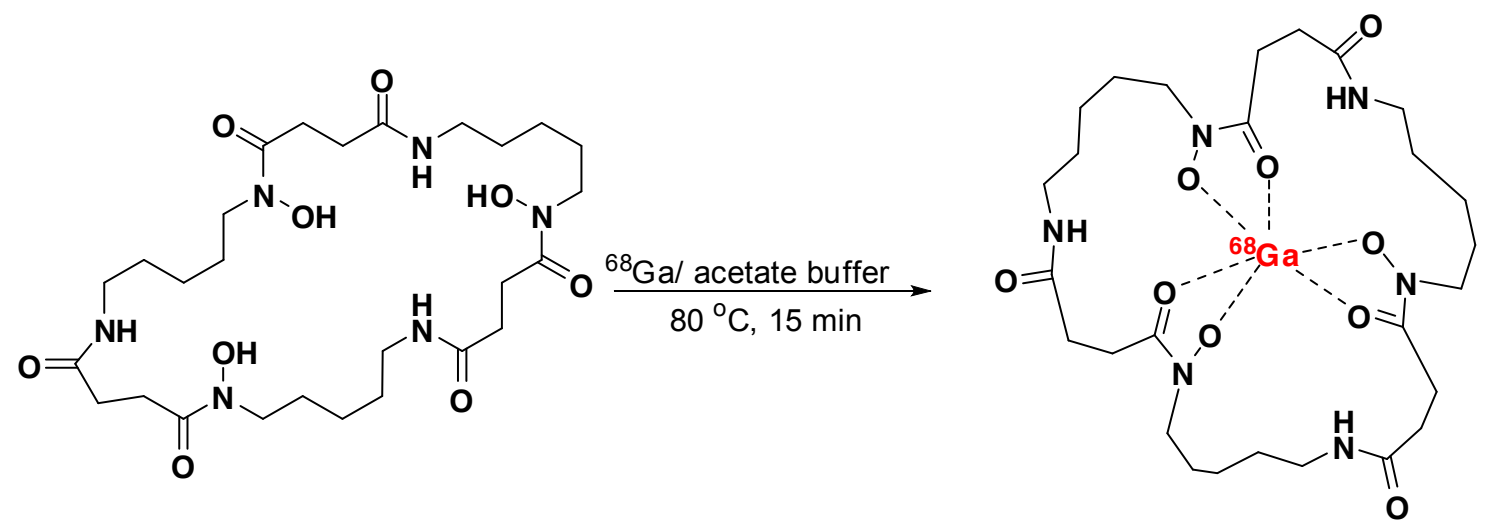

Scheme 35. Synthesis of ${ }^{68} \mathrm{Ga}-\mathrm{FOXE}$ 
Table 4 Novel biomimetic radiotracers for infection imaging

\begin{tabular}{|c|c|c|c|c|c|c|c|}
\hline Compound class & $\begin{array}{l}\text { Compound } \\
\text { name }\end{array}$ & $\begin{array}{l}\text { Radio- } \\
\text { isotope }\end{array}$ & Targeted microorganism(s) & $\begin{array}{l}\text { T/NT } \\
\text { ratio }\end{array}$ & $\begin{array}{l}\text { Labelling } \\
\text { efficiency }\end{array}$ & Method & Reference \\
\hline \multirow{2}{*}{ Vitamins } & Biotin & $\begin{array}{l}{ }^{111} \mathrm{In} \\
{ }^{68} \mathrm{Ga}\end{array}$ & $\begin{array}{l}\text { S. aureus, M.tuberculosis, Aspergillus and } \\
\text { Propionibacterium acnes }\end{array}$ & -- & $>98 \%$ & SPECT/CT & [191] \\
\hline & $\begin{array}{l}\text { Cyano- } \\
\text { cobalamin }\end{array}$ & ${ }^{99 \mathrm{~m}} \mathrm{Tc}$ & S. aureus and E. coli & -- & $95 \%$ & $\begin{array}{l}\text { SPECT/CT } \\
\text { scans }\end{array}$ & {$[194]$} \\
\hline \multirow{2}{*}{ Aptamers } & $\begin{array}{l}\text { SA20, SA23 and } \\
\text { SA34 }\end{array}$ & ${ }^{99 \mathrm{~m}} \mathrm{Tc}$ & S.aureus, C.albicans & $4.0 \pm 0.5$ & $91-93 \%$ & $\begin{array}{l}\text { Gamma } \\
\text { counter }\end{array}$ & [198] \\
\hline & $\begin{array}{l}\text { MORF, PNA, } \\
\text { PS-DNA }\end{array}$ & ${ }^{99 \mathrm{~m}} \mathrm{Tc}$ & S. aureus, K. pneumoniae and E.coli & -- & $95 \%$ & SPECT/CT & {$[199]$} \\
\hline Ribosomal inhibitors & Puromycin & ${ }^{68} \mathrm{Ga}$ & S.aureus & -- & $65 \pm 3 \%$ & $\mu \mathrm{PET} / \mathrm{CT}$ & {$[203]$} \\
\hline Purins and Pyrimidins & FIAU & ${ }^{125} \mathrm{I}$ & $\begin{array}{l}\text { S. aureus, E. faecalis, Proteus mirabilis, } \\
\text { Pseudomonas aeruginosa etc }\end{array}$ & 14 & $50 \%$ & $\mathrm{PET} / \mathrm{CT}$ & {$[205,206]$} \\
\hline \multirow{4}{*}{ Bacterial sugars } & Maltose & ${ }^{18} \mathrm{~F}$ & E. coli & & $5-8 \%$ & PET & {$[208]$} \\
\hline & Maltohexaose & ${ }^{18} \mathrm{~F}$ & E.coli & -- & -- & PET & {$[210]$} \\
\hline & Sorbitol & ${ }^{18} \mathrm{~F}$ & E.coli, S. aureus, Enterobacteriaceae & $12.4 \pm 0.44$ & $81 \pm 4 \%$ & $\mathrm{PET} / \mathrm{CT}$ & {$[211]$} \\
\hline & FAG & ${ }^{18} \mathrm{~F}$ & E.coli & -- & $10 \% \pm 3 \%$ & PET & [216] \\
\hline \multirow{2}{*}{ Siderophores } & TAFC & ${ }^{68} \mathrm{Ga}$ & \multirow{2}{*}{ A. fumigatus } & $5.81 \pm 6.05$ & -- & $\mathrm{PET} / \mathrm{CT}$ & {$[221]$} \\
\hline & FOXE & ${ }^{68} \mathrm{Ga}$ & & $6.64 \pm 2.91$ & -- & $\mathrm{PET} / \mathrm{CT}$ & [221] \\
\hline
\end{tabular}




\section{Challenges and limitations in producing efficient infection imaging probes}

The production of radiopharmaceuticals is often expensive and requires appropriate shielding or particular laboratory set-up to adhere to current guidelines and rules by incorporating good manufacturing procedures (GMP). A favorable imaging agent for infection imaging should be straightforward and rapid to manufacture, if possible at ambient temperatures. Easy-to-radiolabel kit solutions may allow for inexpensive probe manufacture and generates commercialization opportunities. The probe's clinical performance may be limited by its specific activity to assure a sensitive discovery of any unknown infection sites as only trace amounts of the biomolecule forms part of the radiopharmaceutical dose. In addition, most radiosynthesis suffer from the use of solvents during the radiolabeling approach; however it is desirable to eliminate all solvent agents as they may lead to unfavorable reactions or can manipulate the probe's pharmacokinetics and biodistribution. Regarding its chemical production, the desired imaging agent might be of neutral charge to avoid any unnecessary unspecific binding in vivo [223]. Moreover, the production of certain radioisotopes $\left({ }^{11} \mathrm{C},{ }^{13} \mathrm{~N}\right.$, or $\left.{ }^{15} \mathrm{O}\right)$ may be a logistical obstruction due to their exceptionally rapid radioactive decay. This may challenge their broad clinical application, except if being utilized on-site. There is also a significant radiation burden to personnel during production and whilst patient administration.

Aside from the synthetic limitations, the microorganisms within an infection site are posing a challenge for imaging technologies as they have their own cellular mechanisms defending antibiotic or antimicrobial treatments [83, 224]. Prior to diagnosing bacterial manifestation, most tracers are administered intravenously, which makes them prone to radioisotope decoupling form the targeting vector (e.g. de- 
fluorination or trans-chelation) or enzymatic inactivation (e.g. nucleases targets aptamers) resulting in a lowered probe sensitivity. In addition, unabridged penetration of a probe into the infectious tissue is paramount for optimal imaging results. If those parameters may be compromised the corresponding signal-to-noise ratios may limit the justification of the actual bacterial burden in the infection site using nuclear imaging as a sole approach $[7,82,85]$.

In the era of bacterial resistance, multidrug-resistant tuberculosis (MDR-TB) as well as methicillin-resistant staphylococcal (MRSA) or Penicillin-resistant streptococcal stains (PRSC) are becoming a major socio-economic burden. Concerning the diagnostic of TB and MDR-TB using nuclear imaging, most of the commercially available probes have been utilized with varying success $[225,226]$. Predominately ${ }^{18}$ F-FDG-PET was used effectively, for instance to diagnose MRSA-induced endocarditis [227]. Additionally, ${ }^{18}$ FDG-PET was recently reported indicative to monitor anti-TB treatment effects in a MDR-TB population [228]. Moreover, for instance ${ }^{99 \mathrm{~m}} \mathrm{Tc}-\mathrm{UBI}$ and ${ }^{18} \mathrm{~F}-\mathrm{FDS}$ were developed considering probe specificity and sensitivity to MRSA or extendedspectrum $\beta$-lactamase-producing and carbapenem-resistant Enterobacteriaceae, respectively. Interestingly, the diagnostic capabilities and pharmacokinetics of these probes were not substantially compromised targeting the resistant strains [87, 90, 212]. Hopefully, such tailored bacteria-targeting probes can be translated into clinical use in the near future.

\section{Conclusion}

In this review article, we discussed the potential of well-known and novel probes available for non-invasive infection imaging. Even though substantial efforts were made to study the field of infection imaging tracers, only a handful of them are FDA 
approved and commercially available. Moreover, the existing imaging techniques are not regularly used for bacterial diagnosis in clinical setup. Thus far, and despite their challenging radiosyntheses, SPECT/CT using radiolabeled leukocytes is considered the gold standard procedure for the diagnosis of joint prosthesis, endocarditis, inflammatory bowel diseases and osteomyelitis. Since infectious diseases and bacterial resistance pair up to be an even greater threat to medical health and the world's economy; we foresee novel imaging technologies such as PET/MRI and SPECT/MRI using bacteria-tailored probes to be the paradigm shift required to meet the urgent need for an early and better diagnosis of the pathogens!

\section{References:}

[1] C. Bunchorntavakul, N. Chamroonkul, D. Chavalitdhamrong, Bacterial infections in cirrhosis: A critical review and practical guidance, World J. Hepatol. 8 (2016) 307-321.

[2] D.M. Morens, G.K. Folkers, A.S. Fauci, The challenge of emerging and re-emerging infectious diseases, Nature 430 (2004) 242-249.

[3] M. Cupić, I. Lazarević, A. Knezević, M. Stanojević, Conventional and molecular methods in diagnosis and monitoring of viral infection, Srp. Arh. Celok. Lek. 135 (2006) 589-593.

[4] S.J. Goldsmith, S. Vallabhajosula, Clinically proven radiopharmaceuticals for infection imaging: mechanisms and applications, in: Semin. Nucl. Med., Elsevier, 2009, pp. 2-10.

[5] C. Tsopelas, Radiotracers Used for the Scintigraphic Detection of Infection and Inflammation, Scientific World J. 2015 (2015) 1-33.

[6] A. Signore, S.J. Mather, G. Piaggio, G. Malviya, R.A. Dierckx, Molecular Imaging of Inflammation / Infection : Nuclear Medicine and Optical Imaging Agents and Methods, Chem. Rev. 110 (2010) 3112-3145.

[7] T. Ebenhan, O. Gheysens, H.G. Kruger, J.R. Zeevaart, M.M. Sathekge, Antimicrobial peptides: their role as infection-selective tracers for molecular imaging, Biomed. Res. Int. 2014 (2014) 867381.

[8] A. Bunschoten, M.M. Welling, M.F. Termaat, M. Sathekge, F.W.B. Van Leeuwen, Development and prospects of dedicated tracers for the molecular imaging of bacterial infections, Bioconjugate Chem. 24 (2013) 1971-1989.

[9] M. Sathekge, The potential role of 68Ga-labeled peptides in PET imaging of infection, Nucl. Med. Commun. 29 (2008) 663-665.

[10] A.A. Ordonez, E.A. Weinstein, L.E. Bambarger, V. Saini, Y.S. Chang, V.P. DeMarco, M.H. Klunk, M.E. Urbanowski, K.L. Moulton, A.M. Murawski, S. Pokkali, A.S. Kalinda, S.K. Jain, A Systematic Approach for Developing Bacteria-Specific Imaging Tracers, J. Nucl. Med. 58 (2017) 144-150.

[11] T.F. Massoud, S.S. Gambhir, Molecular imaging in living subjects: seeing fundamental biological processes in a new light, Genes Dev. 17 (2003) 545-580. 
[12] J. Ady, Y. Fong, Imaging for Infection: From Visualization of Inflammation to Visualization of Microbes, Surg. Infect. 15 (2014) 700-707.

[13] P.J. MOUNTFORD, M.J. ALLSOPP, A.C. BAIRD, C.I. NORTH, F.M. HALL, C.P. WELLS, A.J. COAKLEY, A study of leucocyte labelling efficiencies obtained with 111 In-oxine, Nucl. Med. Commun. 6 (1985) 109-114.

[14] M. Roca, E.F. de Vries, F. Jamar, O. Israel, A. Signore, Guidelines for the labelling of leucocytes with 111In-oxine, Eur. J. Nucl. Med. Mol. Imaging 37 (2010) 835-841.

[15] P.J. Mountford, A.G. Kettle, M.J. O'Doherty, A.J. Coakley, Comparison of technetium-99mHM-PAO leukocytes with indium-111-oxine leukocytes for localizing intraabdominal sepsis, J. Nucl. Med. 31 (1990) 311-315.

[16] A. Signore, A.W. Glaudemans, The molecular imaging approach to image infections and inflammation by nuclear medicine techniques, Ann. Nucl. Med. 25 (2011) 681-700.

[17] V.K. Verma, S.S. Beevi, A. Tabassum, K. Kumaresan, R.S. Kamaraju, A.S. Arbab, L.K. Chelluri, In vitro assessment of cytotoxicity and labeling efficiency of 99mTc-HMPAO with stromal vascular fraction of adipose tissue, Nucl. Med. Biol. 41 (2014) 744-748.

[18] C.H. Green, Technetium-99m production issues in the United Kingdom, J. Med. Phys. 37 (2012) 66-71.

[19] R.D. Neirinckx, J.F. Burke, R.C. Harrison, A.M. Forster, A.R. Andersen, N.A. Lassen, The retention mechanism of technetium-99m-HM-PAO: intracellular reaction with glutathione, J. Cereb. Blood Flow Metab. 8 (1988) S4-S12.

[20] M. Chianelli, S. Mather, J. Martin-Comin, A. Signore, Radiopharmaceuticals for the study of 4 inflammatory processes: A review, Nucl. Med. Commun. 18 (1997) 437-458.

[21] R. Hanna, T. Braun, A. Levendel, F. Lomas, Radiochemistry and biostability of autologous leucocytes labelled with 99mTc-stannous colloid in whole blood, Eur. J. Nucl. Med. 9 (1984) 216-219.

[22] R.W. Hanna, F.E. Lomas, Identification of factors affecting technetium 99m leucocyte labelling by phagocytic engulfment and evelopment of an optimal technique, Eur. J. Nucl. Med. 12 (1986) 159-162.

[23] C. McClelland, E. Onuegbulem, N. Carter, M. Leahy, M.J. O'DOHERTY, F. Pooley, T. O'doherty, R.J. Newsam, G. Ensing, P.J. Blower, 99mTc-SnF2 colloid 'LLK': particle size, morphology and leucocyte labelling behaviour, Nucl. Med. Commun. 24 (2003) 191-202.

[24] A.E. SOUTHEE, K.J. LEE, A.F. MCLAUGHLIN, P.W. BORHAM, G.J. BAUTOVICH, J.G. MORRIS, Tc-99m white cell scintigraphy in suspected acute infection, Clin. Nucl. Med. 15 (1990) 71-75.

[25] K. Chik, M. Magee, W. Bruce, R. Higgs, M. Thomas, K. Allman, H. Van der Wall, Tc-99m stannous colloid-labeled leukocyte scintigraphy in the evaluation of the painful arthroplasty, Clin. Nucl. Med. 21 (1996) 838-843.

[26] S. Ramsay, J. Labrooy, R. Norton, B. Webb, Demonstration of different patterns of musculoskeletal, soft tissue and visceral involvement in melioidosis using $99 \mathrm{mTc}$ stannous colloid white cell scanning, Nucl. Med. Commun. 22 (2001) 1193-1199.

[27] S. Boyd, R. Nour, R. Quinn, E. McKay, S. Butler, Evaluation of white cell scintigraphy using indium-111 and technetium-99m labelled leucocytes, Eur. J. Nucl. Med. 20 (1993) 201-206.

[28] N. Carter, C. Eustance, S. Barrington, M. O'DOHERTY, A. Coakley, Imaging of abdominal infection using 99mTc stannous fluoride colloid labelled leukocytes, Nucl. Med. Commun. 23 (2002) 153-160.

[29] V. Kumar, Radiolabeled white blood cells and direct targeting of micro-organisms for infection imaging, Q. J. Nucl. Med. Mol. Imaging 49 (2005) 325-338.

[30] C. Tsopelas, The radiopharmaceutical chemistry of $99 \mathrm{mTc}$-tin fluoride colloid-labeledleukocytes, Q. J. Nucl. Med. Mol. Imaging 49 (2005) 319-324. 
[31] K. Peacock, U. Porn, R. Howman-Giles, E. O'Loughlin, R. Uren, K. Gaskin, S. Dorney, R. Kamath, 99mTc-stannous colloid white cell scintigraphy in childhood inflammatory bowel disease, J. Nucl. Med. 45 (2004) 261-265.

[32] J. BOOTH, Assessment of inflammatory bowel disease activity by technetium $99 \mathrm{~m}$ phagocyte scanning, Gastroenterology 95 (1988) 989-996.

[33] P. Gibson, M. Lichtenstein, N. Salehi, G. Hebbard, J. Andrews, Value of positive technetium-99m leucocyte scans in predicting intestinal inflammation, Gut 32 (1991) 15021507.

[34] M.R. Puncher, P.J. Blower, Labelling of leucocytes with colloidal tech netium-99m-SnF2: an investigation of the labelling process by autoradiography, Eur. J. Nucl. Med. 22 (1995) 101107.

[35] B.H. Mock, D. English, Leukocyte labeling with technetium-99m tin colloids, J. Nucl. Med. 28 (1987) 1471-1477.

[36] H. Gallagher, S.C. Ramsay, J. Barnes, J. Maggs, N. Cassidy, N. Ketheesan, Neutrophil labeling with [99m Tc]-technetium stannous colloid is complement receptor 3-mediated and increases the neutrophil priming response to lipopolysaccharide, Nucl. Med. Biol. 33 (2006) 433-439.

[37] C.J. Palestro, Radionuclide Imaging of Musculoskeletal Infection: A Review, J. Nucl. Med. 57 (2016) 1406-1412.

[38] C.J. Palestro, A.W. Glaudemans, R.A. Dierckx, Multiagent imaging of inflammation and infection with radionuclides, Clin. Transl. Imaging 1 (2013) 385-396.

[39] M. Horger, S.M. Eschmann, C. Pfannenberg, D. Storek, F. Dammann, R. Vonthein, C.D. Claussen, R. Bares, The value of SPET/CT in chronic osteomyelitis, Eur. J. Nucl. Med. Mol. Imaging 30 (2003) 1665-1673.

[40] V. Graute, M. Feist, S. Lehner, A. Haug, P.E. Müller, P. Bartenstein, M. Hacker, Detection of low-grade prosthetic joint infections using $99 \mathrm{mTc}$-antigranulocyte SPECT/CT: initial clinical results, Eur. J. Nucl. Med. Mol. Imaging 37 (2010) 1751-1759.

[41] J. Meller, V. Ivancevic, M. Conrad, S. Gratz, Clinical value of immunoscintigraphy in patients with fever of unknown origin, J. Nucl. Med. 39 (1998) 1248.

[42] A. Hubalewska, D. Dudek, J. Dubiel, E. Płaczkiewicz-Jankowska, B. Huszno, A. Staszczak, W. Frasik, Screening for acute myocarditis-is scintigraphy with $99 \mathrm{~m}$ Tc-anti-granulocyte BW 250/183 an answer, Nucl. Med. Rev. Cent. East. Eur. 7 (2004) 165-169.

[43] T. Györke, L. Duffek, K. Bártfai, E. Makó, K. Karlinger, Á. Mester, Z. Tarján, The role of nuclear medicine in inflammatory bowel disease. A review with experiences of aspecific bowel activity using immunoscintigraphy with $99 \mathrm{~m}$ Tc anti-granulocyte antibodies, Eur. J. Radiol. 35 (2000) 183-192.

[44] A. Blazeski, K. Kozloff, P. Scott, Besilesomab for imaging inflammation and infection in peripheral bone in adults with suspected osteomyelitis, Rep. Med. Imaging 3 (2010) 1-11.

[45] A.W.J.M. Glaudemans, F. Galli, M. Pacilio, A. Signore, Leukocyte and bacteria imaging in prosthetic joint infection, Eur. Cell. Mater. 25 (2012) 61-77.

[46] S.J. Skehan, J.F. White, J.W. Evans, D.R. Parry-Jones, C.K. Solanki, J.R. Ballinger, E.R. Chilvers, A.M. Peters, Mechanism of accumulation of $99 \mathrm{mTc}$-sulesomab in inflammation, J. Nucl. Med. 44 (2003) 11-18.

[47] S. Schroeter, L. Greiner-Bechert, LeukoScan protocol, Nucl. Med. Commun. 22 (2001) 841.

[48] S. Basu, T. Chryssikos, S. Moghadam-Kia, H. Zhuang, D.A. Torigian, A. Alavi, Positron emission tomography as a diagnostic tool in infection: present role and future possibilities, in: Semin. Nucl. Med., Elsevier, 2009, pp. 36-51.

[49] R. Kubota, S. Yamada, K. Kubota, K. Ishiwata, N. Tamahashi, T. Ido, IntratumoralDistribution of fluorine- 18-Fluorodeoxyglucoseln Vivo: High Accumulation in 
MacrophagesandGranulationTissuesStudied by Microautoradiograph, J. Nucl. Med. 33 (1992) 1972-1980.

[50] H.A. Jones, R.J. Clark, C.G. Rhodes, J.B. Schofield, T. Krausz, C. Haslett, In vivo measurement of neutrophil activity in experimental lung inflammation, Am. J. Respir. Crit. Care. Med. 149 (1994) 1635-1639.

[51] D.J. Weisdorf, P.R. Craddock, H.S. Jacob, Glycogenolysis versus glucose transport in human granulocytes: differential activation in phagocytosis and chemotaxis, Blood 60 (1982) 888-893.

[52] J. Shearer, J. Amaral, M. Caldwell, Glucose metabolism of injured skeletal muscle: the contribution of inflammatory cells, Circ. Shock 25 (1988) 131-138.

[53] M.J. CLINE, R.I. LEHRER, Phagocytosis by human monocytes, Blood 32 (1968) 423-435.

[54] N.D. McKay, B. Robinson, R. Brodie, N. Rooke-Allen, Glucose transport and metabolism in cultured human skin fibroblasts, Biochim. Biophys. Acta, Mol. Cell Res. 762 (1983) 198-204.

[55] K. Hamacher, H.H. Coenen, G. Stöcklin, Efficient Stereospecific Synthesis of No-CarrierAdded 2-[18F]-Fluoro-2-Deoxy-D-Glucose Using Aminopolyether Supported Nucleophilic Substitution, J. Nucl. Med. 27 (1986) 235-238.

[56] H.W. Kim, J.M. Jeong, Y.-S. Lee, D.Y. Chi, K.-H. Chung, D.S. Lee, J.-K. Chung, M.C. Lee, Rapid synthesis of [18F]FDG without an evaporation step using an ionic liquid, Appl. Radiat. Isot. 61 (2004) 1241-1246.

[57] C. LOWELL EDWARDS, R. Hayes, Tumor scanning with 67Ga citrate, J. Nucl. Med. 25 (1984) 724-726.

[58] V. Kumar, D.K. Boddeti, (68)Ga-radiopharmaceuticals for PET imaging of infection and inflammation, Recent Results Cancer Res. 194 (2013) 189-219.

[59] A. Rizzello, D. Di Pierro, F. Lodi, S. Trespidi, G. Cicoria, D. Pancaldi, C. Nanni, M. Marengo, M.C. Marzola, A. Al-Nahhas, Synthesis and quality control of $68 \mathrm{Ga}$ citrate for routine clinical PET, Nucl. Med. Commun. 30 (2009) 542-545.

[60] A. Aghanejad, A.R. Jalilian, K. Ardaneh, F. Bolourinovin, H. Yousefnia, A.B. Samani, Preparation and Quality Control of (68)Ga-Citrate for PET Applications, Asia. Ocean J. Nucl. Med. Biol. 3 (2015) 99-106.

[61] M. Vorster, B. Mokaleng, M.M. Sathekge, T. Ebenhan, A modified technique for efficient radiolabeling of $68 \mathrm{Ga}$-citrate from a SnO2-based $68 \mathrm{Ge} / 68 \mathrm{Ga}$ generator for better infection imaging, Hell. J. Nucl. Med. 16 (2013) 193-198.

[62] W. Becker, E. Schomann, W. Fischbach, W. Borner, K. Grüner, Comparison of 99TcmHMPAO and 111 In-oxine labelled granulocytes in man: first clinical results, Nucl. Med. Commun. 9 (1988) 435-448.

[63] A. Delcourt, D. Huglo, T. Prangere, H. Benticha, F. Devemy, D. Tsirtsikoulou, M. Lepeut, P. Fontaine, M. Steinling, Comparison between Leukoscan ${ }^{\circledR}($ Sulesomab) and Gallium-67 for the diagnosis of osteomyelitis in the diabetic foot, Diabetes Metab. 31 (2005) 125-133.

[64] M. Bester, P. Van Heerden, J. Klopper, H. Wasserman, S. Rubow, F. De Klerk, Imaging infection and inflammation in an African environment: Comparison of 99Tcm-HMPAO-labelled leukocytes and 67Ga-citrate, Nucl. Med. Commun. 16 (1995) 599-607.

[65] S. Takahama, Y. Kaku, E. Nakashima, R. Minami, M. Yamamoto, [The Usefulness of the Scan with 67Ga-citrate to Assess the Therapeutic Effect on Pneumocystis pneumonia with HIV-1 Infection], Kansenshogaku Zasshi 89 (2015) 254-258.

[66] S. Auletta, F. Galli, C. Lauri, D. Martinelli, I. Santino, A. Signore, Imaging bacteria with radiolabelled quinolones, cephalosporins and siderophores for imaging infection: a systematic review, Clin. Transl. Imaging 4 (2016) 229-252.

[67] K. Chen, X. Chen, Design and development of molecular imaging probes, Curr. Top. Med. Chem. 10 (2010) 1227-1236. 
[68] T. Ebenhan, N. Chadwick, M.M. Sathekge, P. Govender, T. Govender, H.G. Kruger, B. Marjanovic-Painter, J.R. Zeevaart, Peptide synthesis, characterization and 68 Ga-radiolabeling of NOTA-conjugated ubiquicidin fragments for prospective infection imaging with PET/CT, Nucl. Med. Biol. 41 (2014) 390-400.

[69] K. Chen, P.S. Conti, Target-specific delivery of peptide-based probes for PET imaging, Adv. Drug Delivery Rev. 62 (2010) 1005-1022.

[70] L. Gentilucci, R. De Marco, L. Cerisoli, Chemical modifications designed to improve peptide stability: incorporation of non-natural amino acids, pseudo-peptide bonds, and cyclization, Curr. Pharm. Des. 16 (2010) 3185-3203.

[71] J. THUNDIMADATHIL, A. GANGAKHEDKAR, Improving stability of peptide drugs through chemical modifications, Oligos and Peptides 32 (2014) 35-38.

[72] T. Arnesen, Towards a functional understanding of protein $\mathrm{N}$-terminal acetylation, PLoS Biol. 9 (2011) e1001074.

[73] H.C. Kolb, K. Chen, J.C. Walsh, Q. Liang, H.C. Padgett, F. Karimi, Click chemistry-derived cyclopeptide derivatives as imaging agents for integrins, in, Google Patents, 2010.

[74] A.J. Beer, R. Haubner, M. Goebel, S. Luderschmidt, M.E. Spilker, H.-J. Wester, W.A. Weber, M. Schwaiger, Biodistribution and pharmacokinetics of the $\alpha v \beta 3$-selective tracer $18 \mathrm{~F}$ galacto-RGD in cancer patients, J. Nucl. Med. 46 (2005) 1333-1341.

[75] M.S. Morrison, S.-A. Ricketts, J. Barnett, A. Cuthbertson, J. Tessier, S.R. Wedge, Use of a novel Arg-Gly-Asp radioligand, 18F-AH111585, to determine changes in tumor vascularity after antitumor therapy, J. Nucl. Med. 50 (2009) 116-122.

[76] E. Mittra, M. Goris, A. lagaru, A. Kardan, S. Liu, B. Shen, F. Chin, X. Chen, S. Gambhir, First in man studies of [18F] FPPRGD2: a novel PET radiopharmaceutical for imaging $\alpha v \beta 3$ integrin levels, J. Nucl. Med. 51 (2010) 1433-1433.

[77] V. Rufini, M.L. Calcagni, R.P. Baum, Imaging of neuroendocrine tumors, in: Semin. Nucl. Med., Elsevier, 2006, pp. 228-247.

[78] C.J. Anderson, F. Dehdashti, P.D. Cutler, S.W. Schwarz, R. Laforest, L.A. Bass, J.S. Lewis, D.W. McCarthy, 64CU-TETA-octreotide as a PET imaging agent for patients with neuroendocrine tumors, J. Nucl. Med. 42 (2001) 213-221.

[79] Z. Win, L. Rahman, J. Murrell, J. Todd, A. Al-Nahhas, The possible role of 68 Ga-DOTATATE PET in malignant abdominal paraganglioma, Eur. J. Nucl. Med. Mol. Imaging 33 (2006) 506506.

[80] G. Meisetschläger, T. Poethko, A. Stahl, I. Wolf, K. Scheidhauer, M. Schottelius, M. Herz, H.J. Wester, M. Schwaiger, Gluc-Lys ([18F] FP)-TOCA PET in patients with SSTR-positive tumors: biodistribution and diagnostic evaluation compared with [111/n] DTPA-octreotide, J. Nucl. Med. 47 (2006) 566-573.

[81] A. Dimitrakopoulou-Strauss, P. Hohenberger, U. Haberkorn, H.R. Mäcke, M. Eisenhut, L.G. Strauss, 68Ga-labeled bombesin studies in patients with gastrointestinal stromal tumors: comparison with 18F-FDG, J. Nucl. Med. 48 (2007) 1245-1250.

[82] C.P. Brouwer, M. Wulferink, M.M. Welling, The pharmacology of radiolabeled cationic antimicrobial peptides, J. Pharm. Sci. 97 (2008) 1633-1651.

[83] M.R. Yeaman, N.Y. Yount, Mechanisms of antimicrobial peptide action and resistance, Pharmacol. Rev. 55 (2003) 27-55.

[84] S.M. Okarvi, Peptide-based radiopharmaceuticals: future tools for diagnostic imaging of cancers and other diseases, Med. Res. Rev. 24 (2004) 357-397.

[85] M.S. Akhtar, M.B. Imran, M.A. Nadeem, A. Shahid, Antimicrobial peptides as infection imaging agents: better than radiolabeled antibiotics, Int.J. Pep. 2012 (2012) 965238. 
[86] P.S. Hiemstra, M.T. van den Barselaar, M. Roest, P.H. Nibbering, R. van Furth, Ubiquicidin, a novel murine microbicidal protein present in the cytosolic fraction of macrophages, J. Leukoc. Biol. 66 (1999) 423-428.

[87] C.P. Brouwer, S.J. Bogaards, M. Wulferink, M.P. Velders, M.M. Welling, Synthetic peptides derived from human antimicrobial peptide ubiquicidin accumulate at sites of infections and eradicate (multi-drug resistant) Staphylococcus aureus in mice, Peptides 27 (2006) 2585-2591. [88] G. Ferro-Flores, C. Arteaga de Murphy, M. Pedraza-Lopez, L. Melendez-Alafort, Y.M. Zhang, M. Rusckowski, D.J. Hnatowich, In vitro and in vivo assessment of $99 \mathrm{mTc}-U B I$ specificity for bacteria, Nucl. Med. Biol. 30 (2003) 597-603.

[89] M.S. Akhtar, J. Iqbal, M.A. Khan, J. Irfanullah, M. Jehangir, B. Khan, I. UI-Haq, G. Muhammad, M.A. Nadeem, M.S. Afzal, M.B. Imran, 99mTc-labeled antimicrobial peptide ubiquicidin (29-41) accumulates less in Escherichia coli infection than in Staphlococcus aureus infection, J. Nucl. Med. 45 (2004) 849-856.

[90] C.P. Brouwer, F.F. Gemmel, M.M. Welling, Evaluation of 99mTc-UBI 29-41 scintigraphy for specific detection of experimental multidrug-resistant Staphylococcus aureus bacterial endocarditis, Q. J. Nucl. Med. Mol. Imaging 54 (2010) 442-450.

[91] A. Lupetti, M.M. Welling, U. Mazzi, P.H. Nibbering, E.K. Pauwels, Technetium-99m labelled fluconazole and antimicrobial peptides for imaging of Candida albicans and Aspergillus fumigatus infections, Eur. J. Nucl. Med. Mol. Imaging 29 (2002) 674-679.

[92] M.M. Welling, A. Paulusma-Annema, H.S. Balter, E.K. Pauwels, P.H. Nibbering, Technetium-99m labelled antimicrobial peptides discriminate between bacterial infections and sterile inflammations, Eur. J. Nucl. Med. 27 (2000) 292-301.

[93] L. Melendez-Alafort, A. Nadali, G. Pasut, E. Zangoni, R. De Caro, L. Cariolato, M.C. Giron, I. Castagliuolo, F.M. Veronese, U. Mazzi, Detection of sites of infection in mice using $99 \mathrm{mTc}-$ labeled PN(2)S-PEG conjugated to UBI and 99mTc-UBI: a comparative biodistribution study, Nucl. Med. Biol. 36 (2009) 57-64.

[94] L. Melendez-Alafort, M. Ramirez Fde, G. Ferro-Flores, C. Arteaga de Murphy, M. PedrazaLopez, D.J. Hnatowich, Lys and Arg in UBI: a specific site for a stable Tc-99m complex?, Nucl. Med. Biol. 30 (2003) 605-615.

[95] M.S. Akhtar, A. Qaisar, J. Irfanullah, J. Iqbal, B. Khan, M. Jehangir, M.A. Nadeem, M.A. Khan, M.S. Afzal, I. Ul-Haq, M.B. Imran, Antimicrobial peptide 99mTc-ubiquicidin 29-41 as human infection-imaging agent: clinical trial, J. Nucl. Med. 46 (2005) 567-573.

[96] D. Salber, J. Gunawan, K.J. Langen, E. Fricke, P. Klauth, W. Burchert, S. Zijlstra, Comparison of $99 \mathrm{mTc}$ - and 18F-ubiquicidin autoradiography to anti-Staphylococcus aureus immunofluorescence in rat muscle abscesses, J. Nucl. Med. 49 (2008) 995-999.

[97] S. Zijlstra, J. Gunawan, C. Freytag, W. Burchert, Synthesis and evaluation of fluorine-18 labelled compounds for imaging of bacterial infections with pet, Appl. Radiat. Isot. 64 (2006) 802-807.

[98] T. Ebenhan, J.R. Zeevaart, J.D. Venter, T. Govender, G.H. Kruger, N.V. Jarvis, M.M. Sathekge, Preclinical evaluation of 68Ga-labeled 1,4,7-triazacyclononane-1,4,7-triacetic acidubiquicidin as a radioligand for PET infection imaging, J. Nucl. Med. 55 (2014) 308-314.

[99] Y. Date, M. Nakazato, K. Shiomi, H. Toshimori, K. Kangawa, H. Matsuo, S. Matsukura, Localization of human neutrophil peptide (HNP) and its messenger RNA in neutrophil series, Ann. Hematol. 69 (1994) 73-77.

[100] T. Ganz, M.E. Selsted, D. Szklarek, S. Harwig, K. Daher, D.F. Bainton, R.I. Lehrer, Defensins. Natural peptide antibiotics of human neutrophils, J. Clin. Invest. 76 (1985) 1427.

[101] C. Wilde, J. Griffith, M. Marra, J. Snable, R. Scott, Purification and characterization of human neutrophil peptide 4, a novel member of the defensin family, J. Biol. Chem. 264 (1989) 11200-11203. 
[102] A. Singh, A. Bateman, Q. Zhu, S. Shimasaki, F. Esch, S. Solomon, Structure of a novel human granulocyte peptide with anti-ACTH activity, Biochem. Biophys. Res. Commun. 155 (1988) 524-529.

[103] J.F. Gera, A. Lichtenstein, Human neutrophil peptide defensins induce single strand DNA breaks in target cells, Cell. Immunol. 138 (1991) 108-120.

[104] S. Sharma, I. Verma, G. Khuller, Antibacterial activity of human neutrophil peptide-1 against Mycobacterium tuberculosis H37Rv: in vitro and ex vivo study, Eur. Respir. J. 16 (2000) 112-117.

[105] M.M. Welling, P.S. Hiemstra, M.T. van den Barselaar, A. Paulusma-Annema, P.H. Nibbering, E. Pauwels, W. Calame, Antibacterial activity of human neutrophil defensins in experimental infections in mice is accompanied by increased leukocyte accumulation, J. Clin. Invest. 102 (1998) 1583-1590.

[106] E. Pauwels, M. Welling, R. Feitsma, D. Atsma, W. Nieuwenhuizen, The labeling of proteins and LDL with 99m Tc: a new direct method employing KBH 4 and stannous chloride, Nucl. Med. Biol. 20 (1993) 825-833.

[107] J. Stolk, J. Camps, H. Feitsma, J. Hermans, J. Dijkman, E. Pauwels, Pulmonary deposition and disappearance of aerosolised secretory leucocyte protease inhibitor, Thorax 50 (1995) 645-650.

[108] P.A. RAJ, K.J. ANTONYRAJ, T. KARUNAKARAN, Large-scale synthesis and functional elements for the antimicrobial activity of defensins, Biochem. J. 347 (2000) 633-641.

[109] A. Belaaouaj, Neutrophil elastase-mediated killing of bacteria: lessons from targeted mutagenesis, Microbes Infect. 4 (2002) 1259-1264.

[110] L. Robert, W. Hornbeck, Elastin and elastases, vol I, CRC Press, FL, 1989.

[111] B.L. Roberts, W. Markland, A.C. Ley, R.B. Kent, D.W. White, S.K. Guterman, R.C. Ladner, Directed evolution of a protein: selection of potent neutrophil elastase inhibitors displayed on M13 fusion phage, Proc. Natl. Acad. Sci. U. S. A. 89 (1992) 2429-2433.

[112] A.C. Ley, R.C. Ladner, S.K. Guterman, B.L. Roberts, W. Markland, R.B. Kent, Engineered human-derived kunitz domains that inhibit human neutrophil elastase, in, Google Patents, 1997.

[113] M. Rusckowski, T. Qu, J. Pullman, R. Marcel, A.C. Ley, R.C. Ladner, D.J. Hnatowich, Inflammation and Infection Imaging with a 99mTc-Neutrophil Elastase Inhibitor in Monkeys, J. Nucl. Med. 41 (2000) 363-374.

[114] D.J. Hnatowich, T. Qu, F. Chang, A.C. Ley, Labeling peptides with technetium-99m using a bifunctional chelator of a $\mathrm{N}$-hydroxysuccinimide ester of mercaptoacetyltriglycine, J. Nucl. Med. 39 (1998) 56-64.

[115] M. Liberatore, A. Pala, S. Scaccianoce, C. Anagnostou, U. Di Tondo, E. Calandri, P. D'Elia, M.D. Gross, D. Rubello, Microbial Targeting of 99mTc-Labeled Recombinant Human $\beta$ Defensin-3 in an Animal Model of Infection: A Feasibility Pilot Study, J. Nucl. Med. 50 (2009) 823-826.

[116] A. Weinberg, S. Krisanaprakornkit, B. Dale, Epithelial antimicrobial peptides: review and significance for oral applications, Crit. Rev. Oral Biol. Med. 9 (1998) 399-414.

[117] J. Harder, J. Bartels, E. Christophers, J.-M. Schröder, Isolation and characterization of human $\beta$-defensin-3, a novel human inducible peptide antibiotic, J. Biol. Chem. 276 (2001) 5707-5713.

[118] J.-R. García, F. Jaumann, S. Schulz, A. Krause, J. Rodríguez-Jiménez, U. Forssmann, K. Adermann, E. Klüver, C. Vogelmeier, D. Becker, Identification of a novel, multifunctional $\beta$ defensin (human $\beta$-defensin 3) with specific antimicrobial activity, Cell Tissue Res. 306 (2001) 257-264. 
[119] H.P. Jia, B.C. Schutte, A. Schudy, R. Linzmeier, J.M. Guthmiller, G.K. Johnson, B.F. Tack, J.P. Mitros, A. Rosenthal, T. Ganz, Discovery of new human $\beta$-defensins using a genomicsbased approach, Gene 263 (2001) 211-218.

[120] R. Alberto, R. Schibli, A. Egli, A.P. Schubiger, U. Abram, T.A. Kaden, A Novel Organometallic Aqua Complex of Technetium for the Labeling of Biomolecules: Synthesis of [99mTc $(\mathrm{OH} 2) 3(\mathrm{CO}) 3]+$ from [99mTcO4]- in Aqueous Solution and Its Reaction with a Bifunctional Ligand, J. Am. Chem. Soc. 120 (1998) 7987-7988.

[121] F. Schanbacher, R.E. Goodman, R. Talhouk, Bovine mammary lactoferrin: implications from messenger ribonucleic acid (mRNA) sequence and regulation contrary to other milk proteins, J. Dairy Sci. 76 (1993) 3812-3831.

[122] I.A. García-Montoya, T.S. Cendón, S. Arévalo-Gallegos, Q. Rascón-Cruz, Lactoferrin a multiple bioactive protein: An overview, Biochim. Biophys. Acta, Gen. Subj. 1820 (2012) 226236.

[123] B. Van der Strate, L. Beljaars, G. Molema, M. Harmsen, D. Meijer, Antiviral activities of lactoferrin, Antiviral Res. 52 (2001) 225-239.

[124] Y.E. Öztafl, N. Özgünefl, Lactoferrin: a multifunctional protein, Adv. Mol. Med. 1 (2005) 149-154.

[125] D.A. Rodríguez-Franco, L. Vázquez-Moreno, M.G. Ramos-Clamont, Actividad antimicrobiana de la lactoferrina: Mecanismos y aplicaciones clínicas potenciales, Rev. Latinoam Microbiol. 47 (2005) 101-111.

[126] P. Nibbering, E. Ravensbergen, M. Welling, L. Van Berkel, P. Van Berkel, E. Pauwels, J. Nuijens, Human lactoferrin and peptides derived from its $\mathrm{N}$ terminus are highly effective against infections with antibiotic-resistant bacteria, Infect. Immun. 69 (2001) 1469-1476.

[127] A.M. van der Does, P.J. Hensbergen, S.J. Bogaards, M. Cansoy, A.M. Deelder, H.C. van Leeuwen, J.W. Drijfhout, J.T. van Dissel, P.H. Nibbering, The human lactoferrin-derived peptide hLF1-11 exerts immunomodulatory effects by specific inhibition of myeloperoxidase activity, J. Immunol. 188 (2012) 5012-5019.

[128] H.S. de Koster, R. Amons, W.E. Benckhuijsen, M. Feijlbrief, G.A. Schellekens, J.W. Drijfhout, The use of dedicated peptide libraries permits the discovery of high affinity binding peptides, J. Immunol. Methods 187 (1995) 179-188.

[129] A. Signore, M. Chianelli, C. D'Alessandria, A. Annovazzi, Receptor targeting agents for imaging inflammation/infection: where are we now?, Q. J. Nucl. Med. Mol. Imaging 50 (2006) 236-242.

[130] M.M. Welling, A. Lupetti, H.S. Balter, S. Lanzzeri, B. Souto, A.M. Rey, E.O. Savio, A. Paulusma-Annema, E.K. Pauwels, P.H. Nibbering, 99mTc-labeled antimicrobial peptides for detection of bacterial and Candida albicans infections, J. Nucl. Med. 42 (2001) 788-794.

[131] O. Langer, M. Brunner, M. Zeitlinger, S. Ziegler, U. Müller, G. Dobrozemsky, E. Lackner, C. Joukhadar, M. Mitterhauser, W. Wadsak, In vitro and in vivo evaluation of [18F] ciprofloxacin for the imaging of bacterial infections with PET, Eur. J. Nucl. Med. Mol. Imaging 32 (2005) 143 150.

[132] M. Brunner, O. Langer, G. Dobrozemsky, U. Müller, M. Zeitlinger, M. Mitterhauser, W. Wadsak, R. Dudczak, K. Kletter, M. Müller, [18F] Ciprofloxacin, a new positron emission tomography tracer for noninvasive assessment of the tissue distribution and pharmacokinetics of ciprofloxacin in humans, Antimicrob. Agents Chemother. 48 (2004) 3850-3857.

[133] B.D. Davis, Mechanism of bactericidal action of aminoglycosides, Microbiol. Rev. 51 (1987) 341-350.

[134] L.P. Kotra, J. Haddad, S. Mobashery, Aminoglycosides: Perspectives on Mechanisms of Action and Resistance and Strategies to Counter Resistance, Antimicrob. Agents Chemother. 44 (2000) 3249-3256. 
[135] A. Badbarin, A.R. Jalilian, H. Yousefnia, M. Mazidi, F. Bolourinovin, Optimized preparation and evaluation of 99mTc-Streptomycin, Iran. J. Nucl. Med. 24 (2016) 46-50.

[136] E. Widyasari, M. Sriyani, T. Wibawa, W. Nuraeni, Preparation of $99 \mathrm{~m}$ Tc-Kanamycin Using a Direct Labeling Method, Atom Indones. 41 (2015) 131-137.

[137] K. Özker, I. Urgancioĝlu, 99mTc-gentamicin: Chemical and biological evaluation, Eur. J. Nucl. Med. 6 (1981) 173-176.

[138] A. Van't Veen, D. Gommers, S.J. Verbrugge, P. Wollmer, J.W. Mouton, P.P. Kooij, B. Lachmann, Lung clearance of intratracheally instilled 99mTc-tobramycin using pulmonary surfactant as vehicle, Br. J. Pharmacol. 126 (1999) 1091-1096.

[139] D.J. Weber, N.E. Tolkoff-Rubin, R.H. Rubin, Amoxicillin and potassium clavulanate: an antibiotic combination. Mechanism of action, pharmacokinetics, antimicrobial spectrum, clinical efficacy and adverse effects, Pharmacotherapy 4 (1984) 122-136.

[140] D. Ilem-Ozdemir, O. Caglayan-Orumlu, M. Asikoglu, H. Ozkilic, F. Yilmaz, M. HosgorLimoncu, Evaluation of 99mTc-amoxicillin sodium as an infection imaging agent in bacterially infected and sterile inflamed rats, J. Radioanal. Nucl. Chem. 308 (2016) 995-1004.

[141] F. Yurt Lambrecht, O. Yilmaz, P. Unak, B. Seyitoglu, K. Durkan, H. Baskan, Evaluation of 99mTc-Cefuroxime axetil for imaging of inflammation, J. Radioanal. Nucl. Chem. 277 (2008) 491-494.

[142] M. Sohaib, Z. Khurshid, S. Roohi, Labelling of ceftriaxone with 99mTc and its bio-evaluation as an infection imaging agent, J. Label. Compd. Radiopharm. 57 (2014) 652657.

[143] M. Motaleb, M. El-Kolaly, A. Ibrahim, A.A. El-Bary, Study on the preparation and biological evaluation of $99 \mathrm{mTc}$-gatifloxacin and $99 \mathrm{mTc}$-cefepime complexes, J. Radioanal. Nucl. Chem. 289 (2011) 57-65.

[144] V.G. Barreto, G. Rabiller, F. Iglesias, V. Soroa, F. Tubau, M. Roca, J. Martin-Comin, Gammagrafía con 99m Tc-ceftizoxima en ratas normales y en ratas con absceso inducido, Rev. Esp. Med. Nucl. 24 (2005) 312-318.

[145] S. Mirshojaei, M. Gandomkar, R. Najafi, S.S. Ebrahimi, M. Babaei, A. Shafiei, M. Talebi, Radio labeling, quality control and biodistribution of $99 \mathrm{mTc}$-cefotaxime as an infection imaging agent, J. Radioanal. Nucl. Chem. 287 (2011) 21-25.

[146] M.A. Motaleb, Preparation of 99mTc-cefoperazone complex, a novel agent for detecting sites of infection, J. Radioanal. Nucl. Chem. 272 (2007) 167-171.

[147] P.E. Reynolds, Structure, biochemistry and mechanism of action of glycopeptide antibiotics, Eur. J. Clin. Microbiol. Infect. Dis. 8 (1989) 943-950.

[148] M. Motaleb, M. El-Tawoosy, S. Mohamed, I. Borei, H. Ghanem, A. Massoud, 99m Tclabeled teicoplanin and its biological evaluation in experimental animals for detection of bacterial infection, Radiochemistry 56 (2014) 544-549.

[149] S. Roohi, A. Mushtaq, S.A. Malik, Synthesis and biodistribution of 99mTc-Vancomycin in a model of bacterial infection, Radiochim. Acta 93 (2005) 415-418.

[150] T. Tenson, M. Lovmar, M. Ehrenberg, The Mechanism of Action of Macrolides, Lincosamides and Streptogramin B Reveals the Nascent Peptide Exit Path in the Ribosome, J. Mol. Biol. 330 (2003) 1005-1014.

[151] T.H. Bokhari, F.A. Rizvi, S. Roohi, S. Hina, M. Ahmad, M. Khalid, M. Iqbal, Preparation, biodistribution and scintigraphic evaluation of $(99 \mathrm{~m})$ Tc-lincomycin, Pak. J. Pharm. Sci. 1 (2015) 1965-1970.

[152] S. Hina, M.I. Rajoka, S. Roohi, A. Haque, M. Qasim, Preparation, biodistribution, and scintigraphic evaluation of 99mTc-clindamycin: an infection imaging agent, Appl. Biochem. Biotechnol. 174 (2014) 1420-1433. 
[153] M. Sanad, Labeling and biological evaluation of 99m Tc-azithromycin for infective inflammation diagnosis, Radiochemistry 55 (2013) 539-544.

[154] E. Borai, M. Sanad, A. Fouzy, Optimized chromatographic separation and biological evaluation of $99 \mathrm{~m}$ Tc-clarithromycin for infective inflammation diagnosis, Radiochemistry 58 (2016) 84-91.

[155] M.T. Ercan, T. Aras, I.S. Ünsal, Evaluation of 99mTc-erythromycin and 99mTcstreptomycin sulphate for the visualization of inflammatory lesions, Int. J. Rad. Appl. Instrum. B 19 (1992) 803-806.

[156] S.S. Sastry, R. Jayaraman, Inhibitors of nitrofuran reduction in Escherichia coli: evidence for their existence, partial purification, binding of nitrofurantoin in vitro, and implications for nitrofuran resistance, Arch. Biochem. Biophys. 236 (1985) 252-259.

[157] S.Q. Shah, A.U. Khan, M.R. Khan, Radiosynthesis of 99mTc-nitrofurantoin a novel radiotracer for in vivo imaging of Escherichia coli infection, J. Radioanal. Nucl. Chem. 287 (2011) 417-422.

[158] K.T. Bain, E.T. Wittbrodt, Linezolid for the treatment of resistant gram-positive cocci, Ann. Pharmacother. 35 (2001) 566-575.

[159] F.Y. Lambrecht, O. Yilmaz, K. Durkan, P. Unak, E. Bayrak, Preparation and biodistribution of [131I] linezolid in animal model infection and inflammation, J. Radioanal. Nucl. Chem. 281 (2009) 415-419.

[160] K. Britton, D. Wareham, S. Das, K. Solanki, H. Amaral, A. Bhatnagar, A. Katamihardja, J. Malamitsi, H. Moustafa, V. Soroa, Imaging bacterial infection with $99 \mathrm{mTc}$-ciprofloxacin (Infecton), J. Clin. Pathol. 55 (2002) 817-823.

[161] R.H. Siaens, H.J. Rennen, O.C. Boerman, R. Dierckx, G. Slegers, Synthesis and comparison of 99mTc-enrofloxacin and 99mTc-ciprofloxacin, J. Nucl. Med. 45 (2004) 2088-2094.

[162] M. Motaleb, Radiochemical and biological characteristics of 99mTc-difloxacin and 99mTc-pefloxacin for detecting sites of infection, J. Label. Compd. Radiopharm. 53 (2010) 104109.

[163] M. Motaleb, Preparation and biodistribution of 99mTc-lomefloxacin and 99mTcofloxacin complexes, J. Radioanal. Nucl. Chem. 272 (2007) 95-99.

[164] S.Q. Shah, M.R. Khan, Radiocharacterization of the $99 \mathrm{mTc}-$ rufloxacin complex and biological evaluation in Staphylococcus aureus infected rat model, J. Radioanal. Nucl. Chem. 288 (2011) 373-378.

[165] I. Ibrahim, M. Motaleb, K. Attalah, Synthesis and biological distribution of 99mTcnorfloxacin complex, a novel agent for detecting sites of infection, J. Radioanal. Nucl. Chem. 285 (2010) 431-436.

[166] M.E. Moustapha, H.A. Shweeta, M.A. Motaleb, Technetium-labeled danofloxacin complex as a model for infection imaging, Arabian J. Chem. 9 (2016) S1928-S1934.

[167] A. Singh, J. Verma, A. Bhatnagar, A. Ali, Tc-99m labeled sparfloxacin: A specific infection imaging agent, World J. Nucl. Med. 2 (2003) 103-109.

[168] S. Shahzad, M.A. Qadir, R. Rasheed, S. Anwar, M. Ahmed, In Vivo Studies 99mTcLevofloxacin Freeze Dried Kits in Salmonella typhi, Pseudomonas aeruginosa, and Escherichia coli, Lat. Am. J. Pharm. 34 (2015) 760-765.

[169] S.Q. Shah, M.R. Khan, Radiosynthesis and biological evaluation of the 99m Tc-tricarbonyl moxifloxacin dithiocarbamate complex as a potential Staphylococcus aureus infection radiotracer, Appl. Radiat. Isot. 69 (2011) 686-690.

[170] S.Q. Shah, M.R. Khan, S.M. Ali, Radiosynthesis of 99mTc (CO) 3-clinafloxacin dithiocarbamate and its biological evaluation as a potential Staphylococcus aureus infection radiotracer, Nucl. Med. Mol. Imaging 45 (2011) 248-254. 
[171] S.Q. Shah, A.U. Khan, M.R. Khan, 99mTc (CO) 3-Garenoxacin dithiocarbamate synthesis and biological evolution in rats infected with multiresistant Staphylococcus aureus and penicillin-resistant Streptococci, J. Radioanal. Nucl. Chem. 288 (2011) 171-176.

[172] A.J. Fischman, J.W. Babich, N.M. Alpert, J. Vincent, R.A. Wilkinson, R.J. Callahan, J.A. Correia, R.H. Rubin, Pharmacokinetics of 18F-labeled trovafloxacin in normal and Escherichia coli-infected rats and rabbits studied with positron emission tomography, Clin. Microbiol. Infect. 3 (1997) 63-72.

[173] A.J. Fischman, E. Livni, J. Babich, N. Alpert, Y. Liu, E. Thom, R. Cleeland, B. Prosser, R. Callahan, J. Correia, Pharmacokinetics of 18F-labeled fleroxacin in rabbits with Escherichia coli infections, studied with positron emission tomography, Antimicrob. Agents Chemother. 36 (1992) 2286-2292.

[174] D. Satpati, C. Arjun, R. Krishnamohan, G. Samuel, S. Banerjee, 68Ga-labeled Ciprofloxacin Conjugates as Radiotracers for Targeting Bacterial Infection, Chem. Biol. Drug Des. 87 (2016) 680-686.

[175] N. Singh, A. Bhatnagar, Clinical Evaluation of Efficacy of 99mTC-Ethambutol in Tubercular Lesion Imaging, Tuberc. Res. Treat. 2010 (2010) 1-9.

[176] S.Q. Shah, A.U. Khan, M.R. Khan, Radiosynthesis and biodistribution of 99m Tcrifampicin: a novel radiotracer for in-vivo infection imaging, Appl. Radiat. Isot. 68 (2010) 22552260.

[177] G. Samuel, K. Kothari, S. Banerjee, T. Das, S. Subramanian, M. Kameshwaran, M. Pillai, M. Venkatesh, On the $99 \mathrm{mTc}$-labeling of isoniazid with different $99 \mathrm{mTc}$ cores, J. Label. Compd. Radiopharm. 48 (2005) 363-377.

[178] L. Liu, Y. Xu, C. Shea, J.S. Fowler, J.M. Hooker, P.J. Tonge, Radiosynthesis and bioimaging of the tuberculosis chemotherapeutics isoniazid, rifampicin and pyrazinamide in baboons, J. Med. Chem. 53 (2010) 2882-2891.

[179] I. Chopra, M. Roberts, Tetracycline Antibiotics: Mode of Action, Applications, Molecular Biology, and Epidemiology of Bacterial Resistance, Microbiol. Mol. Biol. Rev. 65 (2001) 232260.

[180] D. İlem-Özdemir, M. Asikoglu, H. Ozkilic, F. Yilmaz, M. Hosgor-Limoncu, S. Ayhan, 99mTcDoxycycline hyclate: a new radiolabeled antibiotic for bacterial infection imaging, J. Label. Compd. Radiopharm. 57 (2014) 36-41.

[181] E. Weinstein, L. Liu, A. Ordonez, H. Wang, J.M. Hooker, P. Tonge, S. Jain, Noninvasive determination of 2-[18F]-fluoroisonicotinic acid hydrazide pharmacokinetics by positron emission tomography in Mycobacterium tuberculosis-infected mice, Antimicrob. Agents Chemother. 56 (2012) 6284-6290.

[182] J. Martin-Comin, V. Soroa, G. Rabiller, R. Galli, L. Cuesta, M. Roca, Diagnosis of bone infection with 99mTc-ceftizoxime, Rev. Esp. Med. Nucl. 23 (2004) 357.

[183] A. Kaul, P.P. Hazari, H. Rawat, B. Singh, T.C. Kalawat, S. Sharma, A.K. Babbar, A.K. Mishra, Preliminary evaluation of technetium-99m-labeled ceftriaxone: infection imaging agent for the clinical diagnosis of orthopedic infection, Int. J. Infect. Dis. 17 (2013) e263-e270.

[184] J. Stanek, S. Mairinger, T. Wanek, C. Kuntner, M. Müller, O. Langer, Automated radiosynthesis of [18 F] ciprofloxacin, Appl. Radiat. Isot. 99 (2015) 133-137.

[185] L. Sarda, A. Saleh-Mghir, C. Peker, A. Meulemans, A.-C. Crémieux, D. Le Guludec, Evaluation of $99 \mathrm{mTc}$-ciprofloxacin scintigraphy in a rabbit model of Staphylococcus aureus prosthetic joint infection, J. Nucl. Med. 43 (2002) 239-245.

[186] S.I. Sazonova, Y.B. Lishmanov, N.V. Varlamova, V.S. Skuridin, Y.N. Ilushenkova, M.R. Karpova, Y.A. Nesterov, Synthesis and experimental study of norfloxacin labeled with technecium-99m as a potential agent for infection imaging, Iran. J. Nucl. Med. 23 (2015) 7381. 
[187] S.Q. Shah, M.R. Khan, Radiolabeling of gemifloxacin with technetium-99m and biological evaluation in artificially Streptococcus pneumoniae infected rats, J. Radioanal. Nucl. Chem. 288 (2011) 307-312.

[188] S.Q. Shah, A.U. Khan, M.R. Khan, Radiosynthesis, biodistribution and scintigraphy of the 99mTc-Teicoplanin complex in artificially infected animal models, J. Label. Compd. Radiopharm. 54 (2011) 145-149.

[189] F. Virzi, B. Fritz, M. Rusckowski, M. Gionet, H. Misra, D. Hnatowich, New indium-111 labeled biotin derivatives for improved immunotargeting, Int. J. Rad. Appl. Instrum. B 18 (1991) 719725-723726.

[190] P.A. Erba, A.G. Cataldi, C. Tascini, A. Leonildi, C. Manfredi, G. Mariani, E. Lazzeri, 111InDTPA-Biotin uptake by Staphylococcus aureus, Nucl. Med. Commun. 31 (2010) 994-997.

[191] E. Lazzeri, P. Erba, M. Perri, R. Doria, C. Tascini, G. Mariani, Clinical impact of SPECT/CT with In-111 biotin on the management of patients with suspected spine infection, Clin. Nucl. Med. 35 (2010) 12-17.

[192] E. Blom, B. Långström, I. Velikyan, 68Ga-labeling of biotin analogues and their characterization, Bioconjugate Chem. 20 (2009) 1146-1151.

[193] B. Seetharam, N. Li, Transcobalamin II and its cell surface receptor, Vitam. Horm. 59 (2000) 337-366.

[194] D. Baldoni, R. Waibel, P. Bläuenstein, F. Galli, V. lodice, A. Signore, R. Schibli, A. Trampuz, Evaluation of a Novel Tc-99m Labelled Vitamin B12 Derivative for Targeting Escherichia coli and Staphylococcus aureus In Vitro and in an Experimental Foreign-Body Infection Model, Mol. Imaging Biol. 17 (2015) 829-837.

[195] R. Waibel, H. Treichler, N.G. Schaefer, D.R. van Staveren, S. Mundwiler, S. Kunze, M. Küenzi, R. Alberto, J. Nüesch, A. Knuth, New derivatives of vitamin B12 show preferential targeting of tumors, Cancer Res. 68 (2008) 2904-2911.

[196] M. Gijs, A. Aerts, N. Impens, S. Baatout, A. Luxen, Aptamers as radiopharmaceuticals for nuclear imaging and therapy, Nucl. Med. Biol. 43 (2016) 253-271.

[197] Y.S. Kim, J. Chung, M.Y. Song, J. Jurng, B.C. Kim, Aptamer cocktails: enhancement of sensing signals compared to single use of aptamers for detection of bacteria, Biosens. Bioelectron. 54 (2014) 195-198.

[198] S.R. dos Santos, C.R. Corrêa, A.L.B. de Barros, R. Serakides, S.O. Fernandes, V.N. Cardoso, A.S.R. de Andrade, Identification of Staphylococcus aureus infection by aptamers directly radiolabeled with technetium-99m, Nucl. Med. Biol. 42 (2015) 292-298.

[199] L. Chen, Y. Wang, D. Cheng, X. Liu, S. Dou, G. Liu, D.J. Hnatowich, M. Rusckowski, 99m Tc-MORF oligomers specific for bacterial ribosomal RNA as potential specific infection imaging agents, Bioorg. Med. Chem. 21 (2013) 6523-6530.

[200] Y. Wang, G. Liu, D.J. Hnatowich, Methods for MAG3 conjugation and 99mTc radiolabeling of biomolecules, Nat. Protoc. 1 (2006) 1477-1480.

[201] L. Chen, D. Cheng, G. Liu, S. Dou, Y. Wang, X. Liu, Y. Liu, M. Rusckowski, Detection of Klebsiella. Pneumoniae Infection with an Antisense Oligomer Against its Ribosomal RNA, Mol. Imaging Biol. 18 (2016) 527-534.

[202] M. Azzam, I. Algranati, Mechanism of puromycin action: fate of ribosomes after release of nascent protein chains from polysomes, Proc. Natl. Acad. Sci. U. S. A. 70 (1973) 3866-3869.

[203] S. Eigner, D. Beckford Vera, O. Lebeda, K. Eigner Henke, 68Ga-DOTA-Puromycin: In vivo imaging of bacterial infection, J. Nucl. Med. 54 (2013) 1218.

[204] R.G. Blasberg, J.G. Tjuvajev, Molecular-genetic imaging: current and future perspectives, J. Clin. Invest. 111 (2003) 1620-1629. 
[205] C. Bettegowda, C.A. Foss, I. Cheong, Y. Wang, L. Diaz, N. Agrawal, J. Fox, J. Dick, L.H. Dang, S. Zhou, Imaging bacterial infections with radiolabeled 1-(2'-deoxy-2'-fluoro- $\beta$-Darabinofuranosyl)-5-iodouracil, Proc. Natl. Acad. Sci. U. S. A. 102 (2005) 1145-1150.

[206] L.A. Diaz Jr, C.A. Foss, K. Thornton, S. Nimmagadda, C.J. Endres, O. Uzuner, T.M. Seyler, S.D. Ulrich, J. Conway, C. Bettegowda, Imaging of musculoskeletal bacterial infections by [124 I] FIAU-PET/CT, PLoS One 2 (2007) e1007.

[207] W. Boos, H. Shuman, Maltose/maltodextrin system of Escherichia coli: transport, metabolism, and regulation, Microbiol. Mol. Biol. Rev. 62 (1998) 204-229.

[208] M. Namavari, G. Gowrishankar, A. Hoehne, E. Jouannot, S.S. Gambhir, Synthesis of [18F] labelled Maltose Derivatives as PET Tracers for Imaging Bacterial Infection, Mol. Imaging Biol. 17 (2015) 168-176.

[209] G. Gowrishankar, M. Namavari, E.B. Jouannot, A. Hoehne, R. Reeves, J. Hardy, S.S. Gambhir, Investigation of 6-[18 F]-fluoromaltose as a novel PET tracer for imaging bacterial infection, PLoS One 9 (2014) e107951.

[210] X. Ning, W. Seo, S. Lee, K. Takemiya, M. Rafi, X. Feng, D. Weiss, X. Wang, L. Williams, V.M. Camp, Fluorine-18 labeled maltohexaose images bacterial infections by PET, Angew. Chem., Int. Ed. Engl. 53 (2014) 14096-14101.

[211] Z.-B. Li, Z. Wu, Q. Cao, D.W. Dick, J.R. Tseng, S.S. Gambhir, X. Chen, The synthesis of 18FFDS and its potential application in molecular imaging, Mol. Imaging Biol. 10 (2008) 92-98.

[212] E.A. Weinstein, A.A. Ordonez, V.P. DeMarco, A.M. Murawski, S. Pokkali, E.M. MacDonald, M. Klunk, R.C. Mease, M.G. Pomper, S.K. Jain, Imaging Enterobacteriaceae infection in vivo with $18 \mathrm{~F}$-fluorodeoxysorbitol positron emission tomography, Sci. Transl. Med. 6 (2014) 259ra146-259ra146.

[213] S. Yao, H. Xing, W. Zhu, Z. Wu, Y. Zhang, Y. Ma, Y. Liu, L. Huo, Z. Zhu, Z. Li, Infection imaging with 18 F-FDS and first-in-human evaluation, Nucl. Med. Biol. 43 (2016) 206-214.

[214] K.M. Backus, H.I. Boshoff, C.S. Barry, O. Boutureira, M.K. Patel, F. D'Hooge, S.S. Lee, L.E. Via, K. Tahlan, C.E. Barry, B.G. Davis, Uptake of unnatural trehalose analogs as a reporter for Mycobacterium tuberculosis, Nat. Chem. Biol. 7 (2011) 228-235.

[215] S.R. Rundell, Z.L. Wagar, L.M. Meints, C.D. Olson, M.K. O'Neill, B.F. Piligian, A.W. Poston, R.J. Hood, P.J. Woodruff, B.M. Swarts, Deoxyfluoro-d-trehalose (FDTre) analogues as potential PET probes for imaging mycobacterial infection, Org. Biomol. Chem. 14 (2016) 8598-8609.

[216] M.E. Martínez, Y. Kiyono, S. Noriki, K. Inai, K.S. Mandap, M. Kobayashi, T. Mori, Y. Tokunaga, V.N. Tiwari, H. Okazawa, New radiosynthesis of 2-deoxy-2-[18 F] fluoroacetamidoD-glucopyranose and its evaluation as a bacterial infections imaging agent, Nucl. Med. Biol. 38 (2011) 807-817.

[217] M. Wittenwiler, Mechanisms of Iron Mobilization by Siderophores, Master Studies in Environmental Sciences Master, ETH Zürich (2007).

[218] E.-I. Koh, J.P. Henderson, Microbial copper-binding siderophores at the host-pathogen interface, J. Biol. Chem. 290 (2015) 18967-18974.

[219] R.A. Atkinson, A.L.M. Salah El Din, B. Kieffer, J.-F. Lefèvre, M.A. Abdallah, Bacterial iron transport: $1 \mathrm{H}$ NMR determination of the three-dimensional structure of the gallium complex of pyoverdin G4R, the peptidic siderophore of Pseudomonas putida G4R, Biochemistry 37 (1998) 15965-15973.

[220] T. Emery, P.B. Hoffer, Siderophore-mediated mechanism of gallium uptake demonstrated in the microorganism Ustilago sphaerogena, J. Nucl. Med. 21 (1980) 935-939.

[221] M. Petrik, G.M. Franssen, H. Haas, P. Laverman, C. Hörtnagl, M. Schrettl, A. Helbok, C. Lass-Flörl, C. Decristoforo, Preclinical evaluation of two (68)Ga-siderophores as potential radiopharmaceuticals for Aspergillus fumigatus infection imaging, Eur. J. Nucl. Med. Mol. Imaging 39 (2012) 1175-1183. 
[222] M. Petrik, H. Haas, P. Laverman, M. Schrettl, G.M. Franssen, M. Blatzer, C. Decristoforo, (68)Ga-Triacetylfusarinine $C$ and (68)Ga-Ferrioxamine E for Aspergillus Infection Imaging: Uptake Specificity in Various Microorganisms, Mol. Imaging Biol. 16 (2014) 102-108.

[223] C.A. Boswell, D.B. Tesar, K. Mukhyala, F.-P. Theil, P.J. Fielder, L.A. Khawli, Effects of Charge on Antibody Tissue Distribution and Pharmacokinetics, Bioconjugate Chem. 21 (2010) 2153-2163.

[224] R.M. Epand, H.J. Vogel, Diversity of antimicrobial peptides and their mechanisms of action, Biochim. Biophys. Acta 1462 (1999) 11-28.

[225] M. Sathekge, A. Maes, Y. D'Asseler, M. Vorster, C. Van de Wiele, Nuclear medicine imaging in tuberculosis using commercially available radiopharmaceuticals, Nucl. Med. Commun. 33 (2012) 581-590.

[226] M. Sathekge, A. Maes, M. Kgomo, A. Stoltz, C. Van de Wiele, Use of 18F-FDG PET to predict response to first-line tuberculostatics in HIV-associated tuberculosis, J. Nucl. Med. 52 (2011) 880-885.

[227] O. Gheysens, N. Lips, T. Adriaenssens, S. Pans, J. Maertens, M.C. Herregods, P. Herijgers, W.E. Peetermans, L. Mortelmans, Septic pulmonary embolisms and metastatic infections from methicillin-resistant Staphylococcus aureus endocarditis on FDG PET/CT, Eur. J. Nucl. Med. Mol. Imaging 39 (2012) 183.

[228] R.Y. Chen, L.E. Dodd, M. Lee, P. Paripati, D.A. Hammoud, J.M. Mountz, D. Jeon, N. Zia, H. Zahiri, M.T. Coleman, M.W. Carroll, J.D. Lee, Y.J. Jeong, P. Herscovitch, S. Lahouar, M. Tartakovsky, A. Rosenthal, S. Somaiyya, S. Lee, L.C. Goldfeder, Y. Cai, L.E. Via, S.K. Park, S.N. Cho, C.E. Barry, 3rd, PET/CT imaging correlates with treatment outcome in patients with multidrug-resistant tuberculosis, Sci. Transl. Med. 6 (2014) 265 ra166. 